\title{
Effects of band placement and nitrogen rate on dry matter accumulation, yield and nitrogen uptake of cabbage, carrot and onion
}

Tapio Salo

Agricultural Research Centre of Finland, Plant Production Research, Crops and Soil, FIN-31600 Jokioinen, Finland, e-mail: tapio.salo@mtt.fi

\author{
ACADEMIC DISSERTATION \\ To be presented, with the permission of the Faculty \\ of Agriculture and Forestry of the University of Helsinki, \\ for public criticism in Auditorium 1041 in Viikki Biocenter, \\ Viikinkaari 5, Helsinki, on October 1st, 1999, at 12 noon.
}




\author{
Supervisor: Professor Martti Esala \\ Plant Production Research \\ Agricultural Research Centre of Finland \\ Reviewers: Professor Irma Voipio \\ Department of Plant Production, Horticulture Section \\ University of Helsinki, Finland \\ Docent Johan Korkman \\ Association of Rural Advisory Centres, SLF \\ Helsinki, Finland \\ Opponent: Dr. Albert L. Smit \\ DLO - Research Institute for Agrobiology and Soil Fertility \\ Wageningen, The Netherlands
}


The present study was carried out at the Agricultural Research Centre of Finland (MTT) during 1993-1999. I wish to extend my gratitude to the Directors of Crops and Soil, late Professor Paavo Elonen and his successor and my supervisor Professor Martti Esala, for offering me the financial and institutional framework for this investigation. I am also grateful to Dr. Antti Jaakkola, Professor of Agricultural Chemistry and Physics at the University of Helsinki, for his guidance and support during the work.

I wish to thank Professor Irma Voipio and Dr. Johan Korkman for valuable advice and constructive criticism. The English manuscript was revised by Mrs. Sevastiana Ruusamo, M.A., and edited by Mrs. Sirpa Suonpää, M.Sc., to whom I express my appreciation for their work. I would also like to thank the Board of the Agricultural and Food Science in Finland for accepting this study for publication in their journal.

Special thanks are due to the technical staff of Crops and Soil, and especially to Mr. Risto Tanni for taking care of the field experiments and Mrs. Erja Äijälä for laboratory analyses and technical assistance. I also wish to thank my colleagues at MTT for providing advice and support over the years. Thanks are due also to the statisticians of MTT for giving advice when ever needed. Financial support by the Kemira Research Foundation and Scientific Foundation of Academic Agronomists is gratefully acknowledged.

Finally, my warmest thanks to my dear Maria, my parents and all my friends, especially at the chess board or the badminton court, for support and periods of relaxation during my studies. 


\section{Contents}

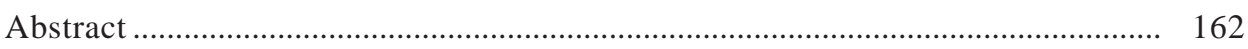

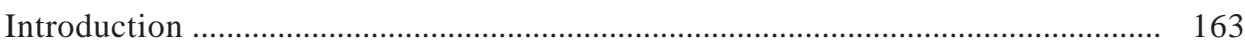

1.1 Nitrogen fertilization for vegetables .................................................... 163

1.1.1 Nitrogen demand ................................................................ 163

1.1.2 Nitrogen losses ........................................................................... 164

1.2 Improving nitrogen recommendations and methods of application .......... 165

1.2.1 Fertilizer recommendations ......................................................... 165

1.2.2 Methods of application ............................................................... 165

1.2.3 Response of experimental crops to nitrogen .................................. 166

1.3 Objectives of the study .................................................................... 167

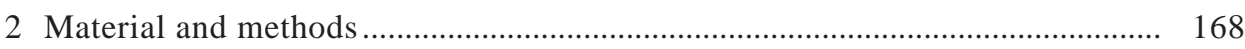

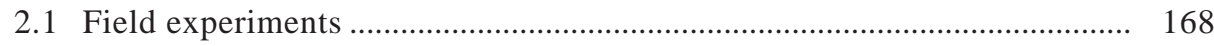

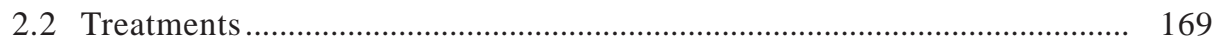

2.2.1 Experimental design ................................................................... 169

2.2.2 Application of fertilizers ......................................................... 170

2.3 Management of field experiments ........................................................ 172

2.4 Soil and plant measurements ................................................................ 174

2.4.1 Soil and root sampling ............................................................... 174

2.4.2 Plant sampling and final yield ..................................................... 176

2.4.3 Laboratory analysis .................................................................... 178

2.4.4 Apparent recovery of fertilizer nitrogen ........................................ 179

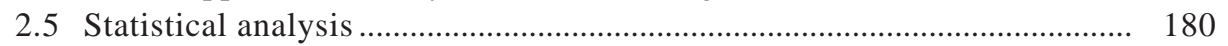

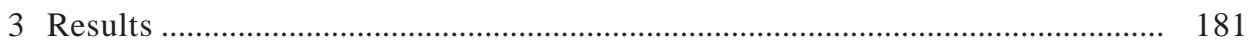

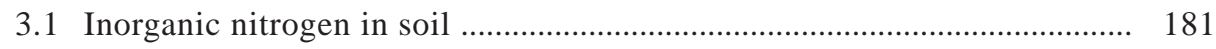

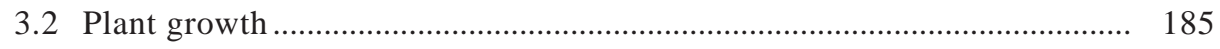

3.2.1 Root length ....................................................................... 185

3.2.2 Dry matter accumulation ............................................................ 187

3.2.3 Final yield ............................................................................... 194

3.2.4 Dry matter content ................................................................. 197

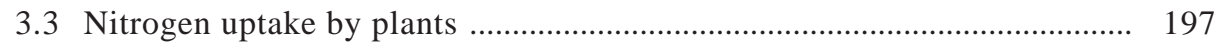

3.3.1 Plant nitrogen concentration ....................................................... 197

3.3.2 Plant nitrogen uptake ..................................................................... 201

3.3.3 Apparent recovery of fertilizer nitrogen ......................................... 207

3.4 Interaction between nitrogen uptake and sample yield .......................... 210

3.5 Interaction between dry matter accumulation and nitrogen concentration 212

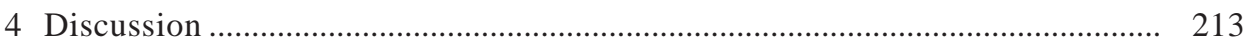

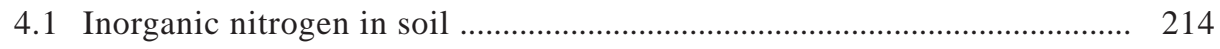

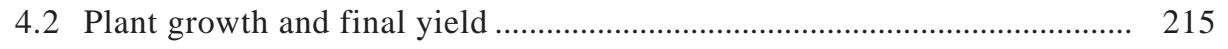

4.3 Nitrogen concentration .................................................................. 220 
AGRICULTURAL AND FOOD SCIENCE IN FINLAND

4.4 Nitrogen uptake ............................................................................... 222

4.5 Apparent recovery of fertilizer nitrogen ................................................. 224

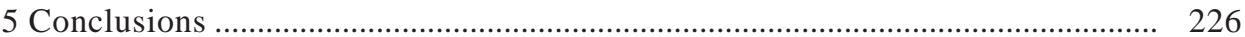

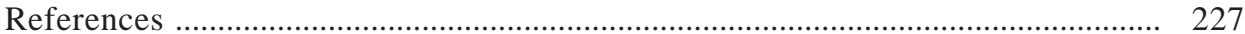

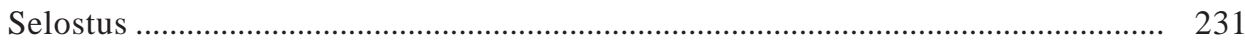




\section{AGRICULTURAL AND FOOD SCIENCE IN FINLAND}

Salo, T. Effects of nitrogen fertilizer on growth of cabbage, carrot and onion

\section{Effects of band placement and nitrogen rate on dry matter accumulation, yield and nitrogen uptake of cabbage, carrot and onion}

Tapio Salo

Agricultural Research Centre of Finland, Plant Production Research, Crops and Soil, FIN-31600 Jokioinen,

Finland, e-mail: tapio.salo@mtt.fi

Adequate nitrogen $(\mathrm{N})$ nutrition is essential for producing high vegetable yields of good quality. Fertilizer $\mathrm{N}$ not taken up by the plants is, however, economically wasteful and can be lost to the environment. Therefore the efficient use of $\mathrm{N}$ fertilizer, involving accurate estimation of crop $\mathrm{N}$ demand, choice of application method and timing of $\mathrm{N}$ fertilization, is an important research area.

The effects of band placement and rate of $\mathrm{N}$ fertilization on inorganic $\mathrm{N}$ in the soil and the dry matter accumulation, yield and $\mathrm{N}$ uptake of cabbage, carrot and onion were studied in a three-year field experiment between 1993 and 1995. The plants were sampled during the growing season to determine the dry matter accumulation and plant $\mathrm{N}$ concentration. The inorganic $\mathrm{N}$ in the soil was determined during the growing period and after harvest.

The $\mathrm{N}$ uptake was $3.8 \mathrm{~kg}, 1.6 \mathrm{~kg}$ and $2.5 \mathrm{~kg}$ per ton of edible yield of cabbage, carrot and onion, respectively. At the highest yield levels the $\mathrm{N}$ uptake including crop residues was $300 \mathrm{~kg} \mathrm{ha}^{-1}, 150 \mathrm{~kg}$ $\mathrm{ha}^{-1}$ and $120 \mathrm{~kg} \mathrm{ha}^{-1}$ in cabbage, carrot and onion, respectively. In cabbage, almost $50 \%$ of $\mathrm{N}$ was in crop residues, whereas in carrot and onion only about $30 \%$ of $\mathrm{N}$ was in crop residues. Nitrogen uptake from non-fertilized soil varied from 29 to $160 \mathrm{~kg} \mathrm{ha}^{-1}$, depending on the growing season and the crop. Cabbage and carrot utilised soil $\mathrm{N}$ efficiently, usually taking up more than $100 \mathrm{~kg} \mathrm{ha}^{-1}$ from non-fertilized soil. Onion, on the contrary, utilised soil $\mathrm{N}$ relatively poorly, usually less than $50 \mathrm{~kg}$ ha $^{-1}$ from non-fertilized soil.

The rate of $\mathrm{N}$ uptake was low with all crops in early summer. After one month, $\mathrm{N}$ uptake increased in cabbage and onion. This uptake continued until harvest, i.e. mid-August for onion and early September for cabbage. Nitrogen uptake by carrot started rapidly only two months after sowing and continued until harvest at the end of September. High $\mathrm{N}$ rates often resulted in high $\mathrm{N}$ concentrations and $\mathrm{N}$ uptakes, but growth was not necessarily increased.

One month after fertilization, most of the $\mathrm{N}$ placed was still near the original fertilizer band and at the depth of 5-10 cm. At that time, broadcast $\mathrm{N}$ was at a depth of $0-5 \mathrm{~cm}$. After harvest the soil mineral $\mathrm{N}$ content was generally low, i.e. below $25 \mathrm{~kg} \mathrm{ha}^{-1}$ at the depth of $0-60 \mathrm{~cm}$. Onion was an exception with poor growth in 1994 , when soil mineral $\mathrm{N}$ after the highest $\mathrm{N}$ rate was $80 \mathrm{~kg} \mathrm{ha}^{-1}$ at a depth of 0-60 cm after harvest.

\footnotetext{
(C) Agricultural and Food Science in Finland
} 


\title{
AGRICULTURAL AND FOOD SCIENCE IN FINLAND
}

Vol. 2 (1999): 157-232.

\begin{abstract}
The placement distance in the cabbage experiment, $7.5 \mathrm{~cm}$ in the side and $7 \mathrm{~cm}$ below cabbage transplants, resulted in lower plant growth and $\mathrm{N}$ uptake than broadcasting of $\mathrm{N}$ at the beginning of the growing periods 1993 and 1994. Towards harvest differences between application methods decreased, although in 1993, placement of $\mathrm{N}$ still led to $6 \%$ lower cabbage yields than broadcasting of $\mathrm{N}$. In 1993, high $\mathrm{N}$ rates increased cabbage dry weight and $\mathrm{N}$ uptake towards harvest, and this effect was more pronounced when $\mathrm{N}$ was broadcast. In 1994, soil N mineralisation was high, and only nonfertilized cabbages took up less $\mathrm{N}$ than fertilized plants.

Carrot was remarkably insensitive to $\mathrm{N}$ fertilization. Carrot yields were similar with and without $\mathrm{N}$ fertilizers. Band placement and $\mathrm{N}$ rate did not affect carrot growth and $\mathrm{N}$ uptake.

In 1993, band placement and high rates of $\mathrm{N}$ increased onion growth and bulb yield more than broadcasting. In 1994, onion growth was poor and treatments did not affect plant $\mathrm{N}$ concentrations or growth. Apparent recovery of fertilizer $\mathrm{N}$ was increased in 1993 by low $\mathrm{N}$ rates or band placement. This result that band placement of $\mathrm{N}$ does not much affect vegetable growth is in agreement with most previous studies. With onion, probably due to the sparse root system, positive effects of $\mathrm{N}$ placement are most likely to be found.
\end{abstract}

Keywords: Allium cepa L., application methods, Brassica oleracea var. capitata L., Daucus carota L., fertilization, growth, nitrogen content

\section{Introduction}

\subsection{Nitrogen fertilization for vegetables}

\subsubsection{Nitrogen demand}

Adequate nitrogen $(\mathrm{N})$ nutrition is essential for producing high crop yields of good quality. As natural soil $\mathrm{N}$ supply is rarely sufficient, growers usually apply fertilizer $\mathrm{N}$ each year. Unused fertilizer $\mathrm{N}$ is economically wasteful and can be lost to the environment. As public awareness of environmental quality increases, there is increasing pressure to improve $\mathrm{N}$ management (Below 1994). The general measures against $\mathrm{N}$ losses are classified as increased crop cover period, optimised application of animal manure and fertilizer to crops, minimum tillage and reduced application of N (Nordic Council of Ministers 1992). Plant $\mathrm{N}$ uptake is approved as a very important way of $\mathrm{N}$ removal from soil and mentioned as one of the important research areas (Nordic Council of Ministers 1992). Whilst efforts to reduce leaching of $\mathrm{N}$ to the environment have caused a slight decrease in the recommended $\mathrm{N}$ rates in many countries, including Finland (Soil Testing Laboratory of Finland 1992, 1997), the effect of reduced $\mathrm{N}$ supply on yield levels should be studied.

Vegetable crops comprise a widely differing species, with a range of $\mathrm{N}$ demand varying from less than $50 \mathrm{~kg} \mathrm{ha}^{-1}$ for peas to more than $300 \mathrm{~kg}$ for white cabbage. In Finnish conditions, the short growing season prevents cultivation of several species and cultivars, and favours management practices, e.g. transplants, that shorten the growing period.

In Finland, the total area of vegetables, including garden peas for the processing industry, has risen above 10000 ha during the 1990's (Information Centre of the Ministry of Agriculture and Forestry 1998). The most popular vegetable crops are garden pea (Pisum sativum L.), white cabbage (Brassica oleracea var. capitata L.), carrot (Daucus carota L.) and onion (Allium cepa L.). Although the total acreage of vegetable crops is not large, the value of production is high and production is usually concentrated on fertile soils. Nitrogen fertilizer recommendations for 


\section{AGRICULTURAL AND FOOD SCIENCE IN FINLAND}

Salo, T. Effects of nitrogen fertilizer on growth of cabbage, carrot and onion

Table 1. Fertilizer recommendations for white cabbage, carrot and onion in Austria, Germany, England and Finland. Expected yields $\left(\mathrm{t} \mathrm{ha}^{-1}\right)$ are given in parentheses after $\mathrm{N}$ recommendations if available. (Bundesgemüsebauverband Österreichs 1995, Scharpf and Weier 1996, MAFF 1994, Soil Testing Laboratory of Finland 1997).

\begin{tabular}{|c|c|c|c|c|c|c|}
\hline \multirow[b]{2}{*}{ Crop } & \multirow[b]{2}{*}{ Harvest } & \multirow[b]{2}{*}{ Soil } & \multicolumn{2}{|c|}{$\begin{array}{l}\mathrm{N} \text { in soil }(0-60 \mathrm{~cm})+\mathrm{N} \text { fertilization } \\
\text { total }\left(\mathrm{kg} \mathrm{ha}^{-1}\right)\end{array}$} & \multicolumn{2}{|c|}{$\begin{array}{l}\mathrm{N} \text { fertilization } \\
\text { total }\left(\mathrm{kg} \mathrm{ha}^{-1}\right)\end{array}$} \\
\hline & & & Austria & Germany & England & Finland \\
\hline \multirow[t]{2}{*}{ Cabbage } & early & sand & & $250(40)$ & 300 & $120(35)$ \\
\hline & late & sand & $280(50)$ & $350(80)$ & 250 & $190(50)$ \\
\hline \multirow[t]{2}{*}{ Carrot } & early & $\begin{array}{l}\text { sand } \\
\text { organic }\end{array}$ & $170(50)$ & & $\begin{array}{r}60 \\
0\end{array}$ & $\begin{array}{l}90(40) \\
80(40)\end{array}$ \\
\hline & late & $\begin{array}{l}\text { sand } \\
\text { organic }\end{array}$ & $215(70)$ & $100(60)$ & $\begin{array}{r}60 \\
0\end{array}$ & $\begin{array}{l}85-95(50) \\
80-90(50)\end{array}$ \\
\hline Onion & & $\begin{array}{l}\text { sand } \\
\text { organic }\end{array}$ & $170(50)$ & $160(60)$ & $\begin{array}{l}90 \\
30\end{array}$ & $\begin{array}{l}90-95(30) \\
80-85(30)\end{array}$ \\
\hline
\end{tabular}

vegetable crops have been established in Finland for more than twenty years (Kurki 1974). The comparisons between the $\mathrm{N}$ fertilizer recommendations in different countries are often confusing, as expected yield, plant density, cultivars and crop management techniques vary considerably. In any case, this comparison (Table 1) can give us an idea of the average level of expected $\mathrm{N}$ demand. According to Neeteson (1995), most of the current $\mathrm{N}$ recommendation systems are based on economically optimum application rates, i.e. they take into account the cost of $\mathrm{N}$ fertilizers and the expected price of the crop products. These recommendations do not consider $\mathrm{N}$ losses to the environment (Neeteson 1995).

\subsubsection{Nitrogen losses}

In Finland, $\mathrm{N}$ losses caused by ammonia volatilisation, denitrification and leaching have been estimated as an average $15 \mathrm{~kg} \mathrm{ha}^{-1}$ per year for each of the loss mechanisms (Nordic Council of Ministers 1992). Whereas leaching can be con- sidered to cause major losses of $\mathrm{N}$ in Northwest Europe (Neeteson 1995), cold winters in Finland decrease the amount of leaching. However with certain crops, as for example cabbages, high fertilizer rates and crop residues rich in $\mathrm{N}$ can increase considerably the risk of $\mathrm{N}$ leaching (Everaarts 1993a).

Denitrification occurs when soil is saturated with water. In vegetable production there are periods after harvest when large amounts of $\mathrm{N}$ and $\mathrm{C}$ in crop residues are in the field (Rahn et al. 1992), and rainfall is high. In Germany, Schloemer (1991) calculated denitrification of $44 \mathrm{~kg}$ $\mathrm{ha}^{-1}$ in 57 days from a cauliflower field where 30 tons of fresh crop residues had been ploughed in.

Although most of the volatilisation of ammonium $\mathrm{N}$ results from animal production systems, some volatilisation can result directly from plants or from decomposing plant residues. Whereas the losses directly from the plants are now estimated to be only $1-2 \mathrm{~kg} \mathrm{ha}^{-1} \mathrm{y}^{-1}$ (Mattsson et al. 1998), losses of ammonia from decomposing plant mulch have been $17-39 \%$ of the $\mathrm{N}$ in the mulch (Larsson et al. 1998). 


\section{AGRICULTURAL AND FOOD SCIENCE IN FINLAND}

Vol. 2 (1999): 157-232.

\subsection{Improving nitrogen recom- mendations and methods of application}

\subsubsection{Fertilizer recommendations}

Different recommendation methods are classified by Neeteson (1995) as follows: fixed rates, $\mathrm{N}_{\text {min }}$ method, balance sheet method, plant analysis and simulation models. These methods are of different complexity. Fixed rates in their simplest form just depend on the expected $\mathrm{N}$ demands of crops. The $\mathrm{N}_{\text {min }}$ method is based on soil inorganic $\mathrm{N}$ analysis at the time of fertilizer application. The balance sheet method attempts to include soil $\mathrm{N}$ mineralisation and atmospheric deposition in the $\mathrm{N}$ recommendation. Plant analysis aims to determine a critical plant $\mathrm{N}$ concentration, below which $\mathrm{N}$ application is needed. Simulation models aim to calculate crop growth, $\mathrm{N}$ uptake, $\mathrm{N}$ supply to soil from different sources and losses of $\mathrm{N}$ to the environment.

Most of the existing $\mathrm{N}$ recommendations include expected yield level. However, correlation between yield and $\mathrm{N}$ uptake of the crop is often not thoroughly determined (Neeteson 1995). Crop $\mathrm{N}$ uptake that originates from $\mathrm{N}$ in the residues of the preceding crop and soil $\mathrm{N}$ mineralisation is generally very difficult to estimate, although the balance sheet method and simulation models aim to do that. The rate of $\mathrm{N}$ uptake during the growing season is important for determining the timing of top dressings. Consideration of root depth is important for determining the soil volume from which the plant can take up N. Finally some crops, as for instance cauliflower, are supposed to need a certain level of soil $\mathrm{N}$ at the time of the harvest to produce a good yield (Welch et al. 1985b). Knowledge of the soil and crop properties discussed above should be increased in order to improve $\mathrm{N}$ recommendations.

Dynamic simulation models, e.g. WELL-N (Rahn et al. 1996a) and N-Expert (Fink and
Scharpf 1993), can be used for N recommendations. Simulation models can be used alone or together with soil and plant analysis which can check and guide the modelling simulations. In addition, the more complicated versions of the models can be used by researchers to understand the behaviour of the agroecosystem. The problem with the models is usually the large amount of data and parameters that is needed. Also the applicability of the models to conditions other than those they were developed for is often poor.

\subsubsection{Methods of application}

Peterson and Frye (1989) classify seven different methods of application. Broadcast application is an even distribution over the field surface, after which the fertilizer is usually mixed into the topsoil. Injection and band placement involve subsurface placement of liquid or solid fertilizer before or during planting. In-row application places the fertilizer directly in the seed row. Side-dressing is applied beside the plant row after crop establishment. Top dressing is a broadcast application over the top of the growing crop. Foliar fertilization means spraying of fertilizer solution directly onto the plant foliage.

Band placement is the main fertilizer application method for cereals in Finland. Compound fertilizers $(10-20 \% \mathrm{~N}, 2-8 \% \mathrm{P}, 4-18 \% \mathrm{~K})$ are placed in bands between every second seed row, 2-3 cm deeper than the seeds. The spacing of seed rows is $12.5 \mathrm{~cm}$ and thus the distance of the fertilizer from the seed is $6-7 \mathrm{~cm}$. From the bands $\mathrm{N}$ dissolves easily in moist soil, and is rapidly available to the plants. The method has resulted in higher cereal yields in several experiments (Kaila and Hänninen 1961, Aura 1967). Band placement has produced the best results in climates with a dry early growing season (Esala and Larpes 1986).

In Finnish outdoor vegetable production, band placement is not a widely used method of $\mathrm{N}$ compared to broadcasting. There are several reasons: lack of suitable machinery, risk of high salt concentrations when a high amount of nu- 


\section{AGRICULTURAL AND FOOD SCIENCE IN FINLAND}

Salo, T. Effects of nitrogen fertilizer on growth of cabbage, carrot and onion

trient is added close to the seed or transplant, and the aim of creating a large, tolerant root system by a uniform nutrient supply in the soil. Top dressings are recommended once or twice during the growing season depending on the crop (Soil Testing Laboratory of Finland 1997). According to the recommendations, $30-50 \%$ of $\mathrm{N}$ rate should be applied as top dressing. Recommendations do not usually mention any difference between band placement or broadcasting of $\mathrm{N}$.

Although vegetable yields were increased in early experiments with the band placement (Cooke et al. 1956), later research has not shown a clear advantage for band application in comparison with broadcast application (Neeteson 1995). Recent studies in England have shown that side-dressing with a small amount of NP fertilizer might hasten plant development and increase plant yield (e.g. Rahn et al. 1996b). Everaarts (1993b) summarizes that beneficial effects of placement are likely to be greatest with crops having a large distance between plants, crops having a short growing period and in soils with low fertility.

\subsubsection{Response of experimental crops to nitrogen}

In Finland, the three most cultivated vegetable crops, excluding garden pea, are carrot, onion and white cabbage (Information Centre of the Ministry of Agriculture and Forestry 1998). Nitrogen recommendations for these crops (Table 1) are based on studies in the early 1980's (Lehtinen 1984, Aura 1985). As these studies included only the effect of $\mathrm{N}$ fertilizer on yield, there is a lack of knowledge concerning $\mathrm{N}$ uptake and the rate of $\mathrm{N}$ uptake in Finnish conditions. Although the recommendations have been revised to meet the yield levels of current cultivars (Soil Testing Laboratory of Finland 1992, 1997), there is still a need to optimise $\mathrm{N}$ application in respect of rate and timing and, in addition, to find out the effects of the application method.
White cabbage, referred to below simply as cabbage, has a distance between plants of 25$60 \mathrm{~cm}$ and the growing period in the field varies from 50 to 140 days in Finnish conditions, depending on the variety (Association of Rural Advisory Centres 1987b). The optimum range of $\mathrm{N}$ fertilizer, shown by several studies, has varied from 200 to $500 \mathrm{~kg} \mathrm{ha}^{-1}$ (Everaarts and de Moel 1998). In Finnish studies, yields have increased up to the highest $\mathrm{N}$ rates used, $240 \mathrm{~kg}$ ha $^{-1}$ (Lehtinen 1984) and $200 \mathrm{~kg} \mathrm{ha}^{-1}$ (Aura 1985). As cabbage plants are wide apart and $\mathrm{N}$ demand is high, cabbage should benefit from $\mathrm{N}$ placement, especially with fast-growing varieties. Wiedenfeld (1986) in Texas, USA and Everaarts and de Moel (1998) in the Netherlands got no or varying effects on cabbage yield by band placement. Cauliflower responded well to placement in Denmark (Sørensen 1996), but Everaarts and de Moel (1995) in the Netherlands got positive effects from band placement in only two experiments out of seven. Considering placement of NPK fertilizer, Smith et al. (1990) in Pennsylvania, USA, found better yields in cabbage with band placement than with broadcasting.

In Finland, carrot has been cultivated with a 45-65 cm row distance (Association of Rural Advisory Centres 1987a). According to Taivalmaa and Talvitie (1997) there has been a change from flat bed to ridge cultivation, and based on their studies they recommended narrow ridges (base width $49 \mathrm{~cm}$ ) for fresh market production and broad ridges (base width $75 \mathrm{~cm}$ ) for industrial production. On the other hand, the growing period of carrot is long for late cultivars, from May to late September. In addition, carrot has a deep root system consisting of very fine roots with a high specific root surface area (Pietola 1995). This might be an additional reason why carrot yield has been relatively insensitive to experiments with water and nitrogen supply as assumed by Pietola (1995). But since placement of NPK fertilizer has resulted in higher carrot yields than broadcasting of NPK fertilizer both in Norway and Finland (Ekeberg 1986, Evers 1989), placement of N solely might also be beneficial for carrot growth. In Finnish studies con- 


\section{AGRICULTURAL AND FOOD SCIENCE IN FINLAND}

Vol. 2 (1999): 157-232.

cerning $\mathrm{N}$ rates, the lowest $\mathrm{N}$ applications used, $60 \mathrm{~kg} \mathrm{ha}^{-1}$ (Lehtinen 1984) and $80 \mathrm{~kg} \mathrm{ha}^{-1}$ (Aura 1985), were sufficient for the highest carrot yields achieved.

In Finland, onion is usually produced from sets, and the length of the growing period is 80 100 days (Engblom 1993). The distance between onion rows is commonly about $30 \mathrm{~cm}$, and as onion has a sparse root system (Portas 1973, Greenwood et al. 1982), it might be expected to benefit from placement of N. Placement of NPK fertilizers (Cooke et al. 1956, Dragland 1992) in England and Norway or NP fertilizers (Sørensen 1996) in Denmark has resulted in slightly higher onion yields compared to broadcasting. According to the results of Henriksen (1987), this effect might be caused mainly by phosphorous. Band placement of $\mathrm{N}$ solely has also increased yields slightly (Wiedenfeld 1986), especially when the amount of $\mathrm{N}$ fertilizer has been low (Sørensen 1996). Although optimum $\mathrm{N}$ rates have varied from 20 to $350 \mathrm{~kg} \mathrm{ha}^{-1}$ in the Netherlands (De Visser et al. 1995), N rates of $50-100 \mathrm{~kg} \mathrm{ha}^{-1}$ have been sufficient to achieve maximum yield in Finland (Aura 1985, Suojala et al. 1998).

\subsection{Objectives of the study}

Field experiments were carried out in order to determine the effect of band placement and $\mathrm{N}$ rate on the growth response, plant $\mathrm{N}$ uptake and apparent recovery of fertilizer N. Three different model crops were cultivated in the same field area during three years. Cabbage cv. Castello F1 (Nickerson-Zwaan, the Netherlands) is used for autumn marketing and industrial purposes in Finland and has a growing period of approximately 85 days (Association of Rural Advisory Centres 1987b). The characteristics observed in England, long field standing ability and high percentage marketable (NIAB 1997) have made Castello popular in Finland. The plant densities used should produce a head weight of $1.5-2.0 \mathrm{~kg}$.
The growth of transplanted cabbage continues in the field with leaf development and then with head formation (Feller et al. 1995). The root system of cabbage has developed about $20 \mathrm{~cm}$ vertically when head formation begins (Portas 1973). Carrot cv. Narbonne F1 (Bejo Zaden, the Netherlands) is a late cultivar in Finnish conditions, and is used for storage (Pessala 1993). Narbonne has good resistance to breakdown and a good yield level (NIAB 1997). The growth stages of carrot in the field are germination, leaf development and finally root expansion (Feller et al. 1995). The root system of carrot is known to be deep and dense (Pietola 1995). Onion cv. Sturon (Sluis and Groot, the Netherlands) is suitable for producing bulbs from sets. Good yield level and storage performance (NIAB 1997) have kept Sturon as one of the most popular onion cultivars in Finland despite its rather mixed size and shape distribution (NIAB 1997). As an onion set has a large reserve of stored assimilates, it rapidly develops into a large plant (Brewster 1990b). After root formation and green shoot emergence, leaf development begins and ceases when bulb development starts (Feller et al. 1995). Bulb development is controlled by temperature and radiation (Brewster 1990a). The root system of onion is unbranched and does not undergo secondary thickening (Langer and Hill 1991).

In this study, these three model crops and cultivars were assessed by the following questions:

What is the relationship between yield and $\mathrm{N}$ uptake?

What is the distribution of $\mathrm{N}$ between yield and crop residues?

What are the potential yield and $\mathrm{N}$ uptake in conditions of low N supply?

Can we determine the critical $\mathrm{N}$ concentration?

When is the most rapid period of $\mathrm{N}$ uptake? What is the apparent recovery of fertilizer N? Is growth increased due to band placement of $\mathrm{N}$ ?

Is the apparent recovery of fertilizer $\mathrm{N}$ increased due to band placement? 


\section{AGRICULTURAL AND FOOD SCIENCE IN FINLAND}

Salo, T. Effects of nitrogen fertilizer on growth of cabbage, carrot and onion

Table 2. Soil properties at the trial sites. Variation is presented in parentheses as standard error of the mean, if available.

\begin{tabular}{lrrrrrrrr}
\hline & \multicolumn{3}{c}{ Experiments without cabbage 1993} & \multicolumn{4}{c}{ Cabbage 1993} \\
& \multicolumn{2}{c}{$0-25 \mathrm{~cm}$} & \multicolumn{2}{c}{$25-50 \mathrm{~cm}$} & \multicolumn{2}{c}{$0-25 \mathrm{~cm}$} & $25-50 \mathrm{~cm}$ \\
\hline Sand $(0.2 \mathrm{~mm} \leq \varnothing<2.0 \mathrm{~mm}), \%$ & 29 & $(9)$ & 16 & $(11)$ & 12 & $(2)$ & 8 & $(1)$ \\
Finesand $(0.02 \leq \varnothing<0.2 \mathrm{~mm}), \%$ & 35 & $(10)$ & 37 & $(7)$ & 22 & $(2)$ & 18 & $(2)$ \\
Silt $(0.002 \mathrm{~mm} \leq \varnothing<0.02 \mathrm{~mm}), \%$ & 10 & $(1)$ & 12 & $(1)$ & 26 & $(2)$ & 26 & $(2)$ \\
Clay $(\varnothing<0.002 \mathrm{~mm}), \%$ & 26 & $(3)$ & 35 & $(4)$ & 40 & $(3)$ & 48 & $(2)$ \\
Total porosity, \% $\left(\mathrm{v} \mathrm{v}^{-1}\right)$ & 48 & $(1)$ & 40 & $(2)$ & 53 & $(1)$ & 49 & $(1)$ \\
Field water capacity $(\mathrm{pF}=2), \%\left(\mathrm{v} \mathrm{v}^{-1}\right)$ & 36 & $(2)$ & 31 & $(2)$ & 36 & $(1)$ & 38 & $(2)$ \\
Wilting point $(\mathrm{pF}=4.2) \%\left(\mathrm{v} \mathrm{v}^{-1}\right)$ & 15 & $(1)$ & 15 & $(1)$ & 21 & $(1)$ & 26 & $(2)$ \\
Saturated hydraulic conductivity & 14 & $(7)$ & 2 & $(1)$ & 26 & $(10)$ & 4 & $(1)$ \\
(cm h-1) & & & & & & & & \\
Total Kjeldahl nitrogen $\left(\mathrm{g} \mathrm{kg}^{-1}\right)$ & 2.0 & $(0.2)$ & 0.6 & $(0.2)$ & 2.2 & $(0.2)$ & 0.7 & $(0.1)$ \\
Total organic carbon $(\%)$ & 2.6 & $(0.2)$ & 0.5 & $(0.1)$ & 3.3 & $(0.3)$ & 1.4 & $(0.9)$ \\
Phosphorus $\left(\mathrm{mg} \mathrm{dm}^{-3}\right)$ & 35 & & 3 & & 47 & $(8)$ & 10 & $(5)$ \\
Potassium $\left(\mathrm{mg} \mathrm{dm}^{-3}\right)$ & 300 & & 180 & & 260 & $(13)$ & 220 & $(15)$ \\
Bulk density $\left(\mathrm{g} \mathrm{cm}^{-3}\right)$ & 1.38 & $(0.03)$ & 1.59 & $(0.06)$ & 1.31 & $(0.02)$ & 1.35 & \\
\hline
\end{tabular}

Methods used:

Particle size distribution by the pipette method (Elonen 1971), total porosity calculated from particle and bulk density (Danielson and Sutherland 1986), field water capacity by pressure plate extractor and wilting point by osmosis (Klute 1986), saturated hydraulic conductivity at the depth $0-25 \mathrm{~cm}$ by ring infiltrometer and at the depth $25-50 \mathrm{~cm}$ by the augerhole method above water table (Youngs 1991), Kjeldahl $\mathrm{N}$ by autoanalyzer (Tecator 1981), organic carbon by a Leco analyzer at $1370^{\circ} \mathrm{C}$ (Sippola 1982), phosphorus and potassium extracted with acid ammonium acetate (Vuorinen and Mäkitie 1955, Kurki et al. 1965) and bulk density by the core method (Blake and Hartge 1986).

\section{Material and methods}

\subsection{Field experiments}

The field site

The field experiments were carried out in the same field area of the Agricultural Research Centre of Finland in Jokioinen $\left(60^{\circ} 49^{\prime} \mathrm{N}\right.$, $23^{\circ} 28^{\prime} \mathrm{E}, 85 \mathrm{~m}$ a.s.1.). According to the soil classification used in Finland (Juusela and Wäre 1956), the top soil was fine sand, except for the cabbage field in 1993 when the soil type was clay loam (Table 2). The subsoils of the experimental fields were sandy and silty clay. The organic matter content (organic C multiplied by 1.94) indicates that the surface soil was medium (3-6\%) in organic matter and the cabbage field in 1993 rich (6-12\%) in organic matter (Aaltonen et al. 1949). Both soils can tentatively be classified as Eutric Cambisol according to the FAO classification (Fitzpatrick 1980).

\section{Weather conditions}

Temperature, potential evaporation (determined by Class-A evaporation pan) and precipitation were measured at the Jokioinen Observatory (Table 3). In 1993, the temperature was slightly lower than long-time average. In 1994, July was extremely dry and warm, with only $1 \mathrm{~mm}$ of precipitation and potential evaporation of $186 \mathrm{~mm}$. In 1995, May and June were very rainy, but later the rainfall was less than the long-time average. Potential evaporation was high in May 1993, but decreased later below the long-time average. In 1994, potential evaporation was first low, but increased up to long-time average values due to warm July. 
Vol. 2 (1999): 157-232.

Table 3. Monthly mean temperatures, monthly sums of potential evaporation, precipitation and irrigation during the growing seasons and 30 year averages at the Jokioinen Observatory.

$1993 \quad 1994 \quad 1995 \quad 1961-90$

Mean temperature $\left({ }^{\circ} \mathrm{C}\right)$

\begin{tabular}{|c|c|c|c|c|}
\hline May & 13.6 & 7.8 & 8.7 & 9.4 \\
\hline June & 11.4 & 12.1 & 16.7 & 14.3 \\
\hline July & 15.6 & 19.0 & 15.3 & 15.8 \\
\hline August & 12.9 & 15.1 & 15.1 & 14.2 \\
\hline September & 5.7 & 10.0 & 10.3 & 9.4 \\
\hline
\end{tabular}

Potential evaporation (mm)

$\begin{array}{lrrrr}\text { May } & 155 & 108 & 86 & 116 \\ \text { June } & 99 & 104 & 128 & 148 \\ \text { July } & 122 & 186 & 136 & 129 \\ \text { August } & 59 & 93 & 109 & 90 \\ \text { September } & 35 & 36 & 38 & 40\end{array}$

Precipitation (mm)

$\begin{array}{lrrrr}\text { May } & 1 & 34 & 87 & 35 \\ \text { June } & 56 & 66 & 121 & 47 \\ \text { July } & 107 & 1 & 53 & 80 \\ \text { August } & 136 & 54 & 65 & 83 \\ \text { September } & 13 & 105 & 45 & 65\end{array}$

Irrigation $(\mathrm{mm})$

\begin{tabular}{|c|c|c|c|c|c|c|c|c|c|}
\hline & $\mathrm{Cb}$ & $\mathrm{Ca}$ & On & $\mathrm{Cb}$ & $\mathrm{Ca}$ & On & $\mathrm{Cb}$ & $\mathrm{Ca}$ & On \\
\hline May & $\overline{20}$ & 20 & 10 & & & & & & \\
\hline June & & & & 10 & & & 10 & & \\
\hline July & 20 & 10 & 10 & 85 & 71 & 77 & 40 & 23 & 60 \\
\hline August & & & & 61 & 36 & 10 & & & \\
\hline
\end{tabular}

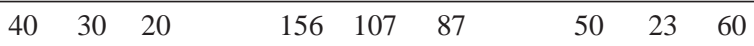

$\mathrm{Cb}=$ cabbage, $\mathrm{Ca}=$ carrot, $\mathrm{On}=$ onion .

\subsection{Treatments}

\subsubsection{Experimental design}

In 1993, factorial experiments were set up according to a split-plot design, where the main plot factor was $\mathrm{N}$ fertilization with three levels $\left(\mathrm{N}_{1}, \mathrm{~N}_{2}, \mathrm{~N}_{3}\right)$ and the subplot factor was broad- cast or band placement application (Table 4). The highest $\mathrm{N}$ level was estimated to be the optimum fertilizer $\mathrm{N}$ rate with respect to expected yield (Soil Testing Laboratory of Finland 1992) and soil $\mathrm{N}$ reserves. In addition, a treatment without $\mathrm{N}$ fertilizer was included in order to measure growth and $\mathrm{N}$ uptake produced by $\mathrm{N}$ mineralized from the soil and to calculate the apparent recovery of fertilizer N. In 1994, cabbage and 


\section{AGRICULTURAL AND FOOD SCIENCE IN FINLAND}

Salo, T. Effects of nitrogen fertilizer on growth of cabbage, carrot and onion

Table 4. Experimental details.

\begin{tabular}{|c|c|c|c|c|c|c|}
\hline Experiment & $\begin{array}{c}\text { Inorganic N } \\
\text { before fertilization } \\
\mathrm{kg} \mathrm{ha}^{-1}\end{array}$ & $\begin{array}{l}\text { Main plot } \\
\mathrm{N} \text { rate } \\
\mathrm{kg} \mathrm{ha}^{-1}\end{array}$ & $\begin{array}{c}\text { Subplot } \\
\text { Application method }\end{array}$ & $\begin{array}{c}\text { Plant density } \\
\text { harvested / planned } \\
\text { plants ha- }\end{array}$ & $\begin{array}{l}\text { Planting } \\
\text { date }\end{array}$ & $\begin{array}{c}\text { Final harvest } \\
\text { date }\end{array}$ \\
\hline Cabbage 1993 & 44 & $0,125,188,250$ & broadcast/band & $62000 / 67000$ & 25 May & 7 September \\
\hline Cabbage 1994 & 27 & $0,80,120,160$ & broadcast/band & $36000 / 44000$ & 1 June & 7 September \\
\hline Cabbage 1995 & 16 & 0,160 & broadcast/band & 33000 / 50000 & 16 June & 3 October \\
\hline Carrot 1993 & 33 & $0,30,70,100$ & broadcast/band & 730000 / 800000 & 4 May & 1 October \\
\hline Carrot 1994 & 44 & $0,30,70,100$ & broadcast & 785000 / 800000 & 6 May & 30 September \\
\hline Carrot 1995 & 22 & 0,70 & broadcast & $155000 / 290000$ & 10 May & 6 October \\
\hline Onion 1993 & 50 & $0,30,70,100$ & broadcast/band & $351000 / 356000$ & 11 May & 17 August \\
\hline Onion 1994 & 38 & $0,30,70,100$ & broadcast/band & $343000 / 356000$ & 10 May & 23 August \\
\hline Onion 1995 & 22 & 0,100 & broadcast & $312000 / 356000$ & 30 May & 29 August \\
\hline
\end{tabular}

Table 5. Crop rotation during the experiment.

\begin{tabular}{lccc}
\hline 1992 & 1993 & 1994 & 1995 \\
\hline Barley & Cabbage & Barley & Barley \\
Barley & Carrot & Cabbage & Onion \\
Barley & Onion & Carrot & Cabbage \\
Barley & Barley & Onion & Carrot \\
\hline
\end{tabular}

onion experiments were conducted with a similar split-plot design as in 1993. As carrot growth in 1993 was not influenced even by $\mathrm{N}$ rate, $\mathrm{N}$ rates were only broadcast in 1994. In 1995, carrot and onion experiments were conducted only with a non-fertilized treatment and an estimated optimum $\mathrm{N}$ rate in order to obtain data for $\mathrm{N}$ mineralisation and $\mathrm{N}$ uptake from the third year. With cabbage, placement and broadcast treatments were included to compare application methods also during the third experimental year. All experiments were made with four replicates, arranged in separate blocks. Randomisation was done by the experimental design procedure of the MSTAT-C program (Michigan State University 1989). Nitrogen fertilizer levels were first randomly assigned to the blocks and then the two application methods were randomised over each main plot. The locations of the experiments were changed from the previous year (Table 5) in order to decrease the risk of disease. As the available field area for the experiments was small, the experiments were often established over the experiment of the previous year. The error caused by $\mathrm{N}$ application the preceding year was assumed to be small due to the leaching of $\mathrm{N}$ during the previous autumn and spring.

\subsubsection{Application of fertilizers}

Autumn ploughed land was harrowed to a depth of $3-5 \mathrm{~cm}$ in order to decrease surface roughness. After that potassium and phosphorus were broadcast on the soil surface and the seed or planting bed was tilled. Nitrogen was applied as ammonium nitrate limestone (27.5\% N, Kemira Agro Oy, Finland), potassium as potassium sulphate $(41.5 \% \mathrm{~K})$ and phosphorus as triple superphosphate $(20.1 \%$ P). Ammonium nitrate was used to protect part of the fertilizer $\mathrm{N}$ from possible leaching at the beginning of the growing period. However, ammonium nitrate should maintain inorganic $\mathrm{N}$ in the soil at a high level right after planting or seeding. A high content of inorganic $\mathrm{N}$ would also test the effect of salt stress. Although experimental soils were assumed to contain enough other macronutrients and micronutrients, $500 \mathrm{~kg} \mathrm{ha}^{-1}$ compound fertilizer $(18.5 \% \mathrm{~S}, 5.0 \% \mathrm{Mg}, 0.3 \% \mathrm{Fe}, 0.3 \% \mathrm{~B}, 1.0 \%$ $\mathrm{Cu}, 4.0 \% \mathrm{Mn}, 0.8 \% \mathrm{Zn}$ and $0.05 \% \mathrm{Mo}$, Kemira Agro Oy, Finland) was applied to the experimental fields each year. 


\section{AGRICULTURAL AND FOOD SCIENCE IN FINLAND}

Vol. 2 (1999): 157-232.

\section{Cabbage}

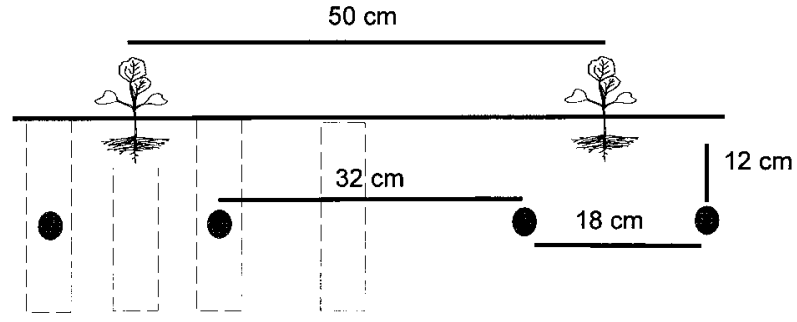

$\begin{array}{llll}\text { FR } & \text { PR } & \text { FR } & \text { IR }\end{array}$

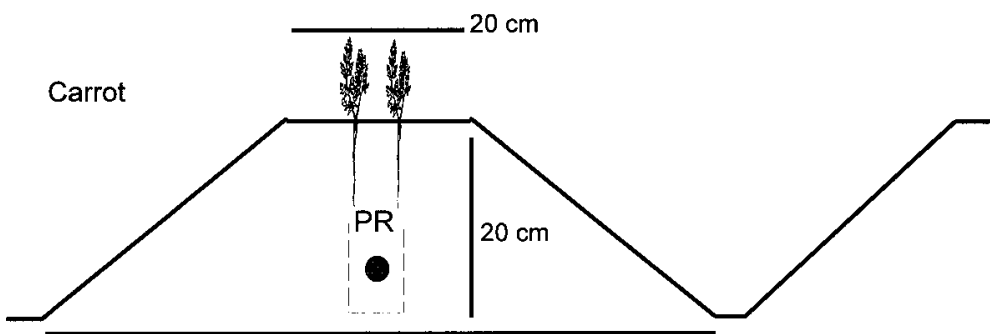

$70 \mathrm{~cm}$

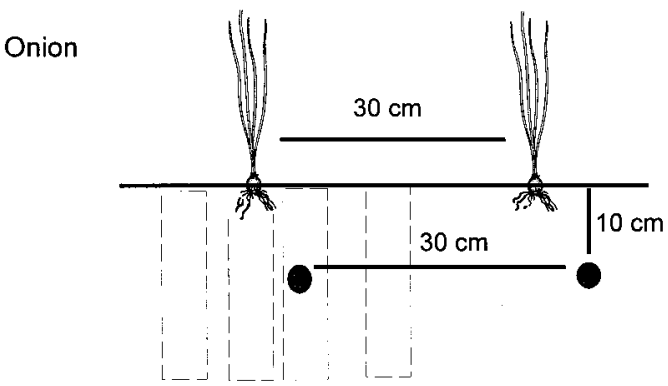

NF PR FR IR

Fig. 1. Locations of $\mathrm{N}$ fertilizer placement and soil samplings of placement treatments.

$\begin{array}{clll}\text { FR } & \text { Fertilizer band } & \text { PR } & \text { Plant row } \\ \text { FR } & \text { Fertilizer row } & \text { IR } & \text { Interrow } \\ \text { NF } & \text { Non-fertilized interrow } & & \end{array}$

\section{Cabbage}

Each year, $150 \mathrm{~kg} \mathrm{ha}^{-1}$ potassium and $50 \mathrm{~kg} \mathrm{ha}^{-1}$ phosphorus were applied according to the slightly higher yield expected than the $50 \mathrm{t} \mathrm{ha}^{-1}$ of the recommendations (Soil Testing Laboratory of Finland 1992). These fertilizers were broadcast and mixed in the $10 \mathrm{~cm}$ soil layer by a rotary harrow.

The $\mathrm{N}$ fertilizer was band-placed using fertilizer drill (Juko Ltd., Finland) in four double rows for each $2 \mathrm{~m}$ wide experimental plot. The distance between double rows was $32 \mathrm{~cm}$ and the rows of the double row were $18 \mathrm{~cm}$ apart (Fig. 1). Fertilizer bands were placed about 12 $\mathrm{cm}$ below the soil surface. Broadcast treatment was made with the same fertilizer drill, first applying fertilizer on the soil surface and then mixing the fertilizer with a harrow into the $8 \mathrm{~cm}$ top layer.

Lower $\mathrm{N}$ rates (Table 4) were applied in 1994 than in 1993 because the $\mathrm{N}$ uptake of the non- 


\section{AGRICULTURAL AND FOOD SCIENCE IN FINLAND}

Salo, T. Effects of nitrogen fertilizer on growth of cabbage, carrot and onion

fertilized carrot crop had been over $100 \mathrm{~kg} \mathrm{ha}^{-1}$ in this experimental field, and the density of cabbage plants was lower in 1994 than in 1993.

\section{Carrot}

Each year, $80 \mathrm{~kg} \mathrm{ha}^{-1}$ potassium and $50 \mathrm{~kg} \mathrm{ha}^{-1}$ phosphorus were applied according to the recommendations for the expected $50 \mathrm{t} \mathrm{ha}^{-1}$ yield (Soil Testing Laboratory of Finland 1992). These fertilizers were broadcast and mixed in the 20 $\mathrm{cm}$ soil layer by a rotary harrow.

In 1993, band placement of $\mathrm{N}$ was done using a potato planting machine (Juko Ltd., Finland) after loosening the soil by a rotary harrow to a depth of $20 \mathrm{~cm}$. The potato planting machine formed a ridge about $20 \mathrm{~cm}$ high, and placed the fertilizer band about $15 \mathrm{~cm}$ below the top of the ridge (Fig. 1). There were four ridges (Fig. 1) in the $3.0 \mathrm{~m}$ wide experimental plot. Broadcast treatment was made with a manually propelled fertilizer spreader working on the principle of an ordinary fertilizer drill (Tume Oy, Finland). The fertilizer was first applied on the soil surface, then mixed by a rotary harrow into the $15 \mathrm{~cm}$ top layer and finally ridges were formed with the potato planting machine.

In 1994 and 1995, N fertilizer was broadcast with the manual fertilizer spreader (Tume Oy, Finland), and then mixed by a rotary harrow into the $15 \mathrm{~cm}$ top soil layer. Ridges were not formed in 1994 and 1995 in order to avoid problems of dry soil surface, which delayed emergence in 1993.

\section{Onion}

Each year, $60 \mathrm{~kg} \mathrm{ha}^{-1}$ potassium and $60 \mathrm{~kg} \mathrm{ha}^{-1}$ phosphorus were applied according to the slightly higher yield expected than the $25 \mathrm{t} \mathrm{ha}^{-1}$ of the recommendations (Soil Testing Laboratory of Finland 1992). These fertilizers were broadcast and mixed into the $8 \mathrm{~cm}$ soil layer by a harrow.

The $\mathrm{N}$ fertilizer was band placed using a potato planting machine (Juko Ltd, Finland), in a single band with a distance of $30 \mathrm{~cm}$ between rows and at a depth of $10 \mathrm{~cm}$ (Fig. 1). There were four fertilizer bands in the $1.5 \mathrm{~m}$ wide experimental plot. Broadcast treatment was made with the manually propelled fertilizer spreader (Tume Oy, Finland). Fertilizer was applied on the soil surface and then mixed with a harrow into the 5 $\mathrm{cm}$ soil layer.

\subsection{Management of field experiments}

In 1993, gypsum blocks were installed at depths of 10 and $20 \mathrm{~cm}$ in broadcast $\mathrm{N}_{1}$ and $\mathrm{N}_{3}$ and placed $\mathrm{N}_{2}$ plots after planting or sowing. In 1994, gypsum blocks were installed at depths of 10, 20 and 30 $\mathrm{cm}$ in the broadcast $\mathrm{N}_{2}$ plots and in the $\mathrm{N}$ fertilized plots in 1995 . The gypsum blocks were usually recorded once a week. When the estimated transpiration was high and rainfall was low, the gypsum blocks were recorded 2-3 times per week. Irrigation was carried out when the plant-available water fell to $40-50 \%$. Irrigation was applied at night by rotary sprinklers (radius $14 \mathrm{~m}$ and angle of irrigated sector $90^{\circ}$ ). The rate of irrigation was approximately $4 \mathrm{~mm}$ per hour. The amount of water given to the sprinkling sector was controlled by $6-9$ plastic flasks equipped with funnels. These sprinklers have $15-25 \%$ variation within the sprinkling sector (Pietola 1995). In spring 1993, irrigation was applied for all crops to secure start of growth after planting or sowing, as the rainfall in May was only $1 \mathrm{~mm}$. In 1994, only the cabbage field was irrigated after planting.

Plant protection was done according to the prevailing Finnish recommendations (Markkula 1993). The manufacturer's instructions were followed in pesticide applications. Yellow traps were used to monitor the abundance of harmful insects. Early in the season weeds were controlled by herbicide applications, and later by handweeding. Protection measures against diseases and insects kept plant damage to a low level except for damage caused by carrot fly (Psila rosae F.) in autumn 1994. 


\section{AGRICULTURAL AND FOOD SCIENCE IN FINLAND}

Vol. 2 (1999): 157-232.

\section{Cabbage}

The subplots were $2 \mathrm{~m} \times 10 \mathrm{~m}$. Cabbage spacing between rows was $0.5 \mathrm{~m}$ and the spacing within rows was $0.3 \mathrm{~m}$ in 1993, $0.45 \mathrm{~m}$ in 1994 and 0.4 $\mathrm{m}$ in 1995 . The plant density was decreased in 1994 as the head weight the previous year had been less than $1.5 \mathrm{~kg}$, which had been set as a target weight. In 1995, the plant density was slightly increased as the transplants were stressed due to delayed planting.

The cabbage transplants were raised in cell trays (Plantek 144, Lännen Tehtaat, Finland) by a local farmer. The cell dimensions of this tray model are $3.2 \mathrm{~cm} \mathrm{x} 3.2 \mathrm{~cm} \mathrm{x} 4 \mathrm{~cm}$. In 1993 and 1994, four-week-old cabbage transplants were planted by hand after night temperatures had risen above $0^{\circ} \mathrm{C}$ (Table 4). Plant rows were positioned in the middle of the double fertilizer band in the placed treatments (Fig. 1). Thus $\mathrm{N}$ bands were $7.5 \mathrm{~cm}$ to the side and $7 \mathrm{~cm}$ below the cabbage transplants, as the cabbage pot inserted $1 \mathrm{~cm}$ below soil surface was $3 \mathrm{~cm}$ wide and $4 \mathrm{~cm}$ long. In 1995, the cabbage transplants were planted later in June, as high rainfalls had kept the soil too moist for planting. As the transplants were delivered at the end of May, they were stored in a greenhouse and watered with NP-solution $(0.015 \% \mathrm{~N}, 0.015 \% \mathrm{P})$ for two weeks. This delayed planting seemed to stress the transplants, as root growth was excessive in the small cell of the tray.

In 1993, the plants were irrigated twice with $10 \mathrm{~mm}$ after planting, and with $20 \mathrm{~mm}$ at the beginning of July when the plant-available water in the soil decreased rapidly. In 1994, the plants were irrigated seven times, the amount of water applied was altogether $156 \mathrm{~mm}$ (Table 3). In 1995, the soil was moist after high rainfall in early summer, and irrigation was applied only three times, altogether $50 \mathrm{~mm}$.

The cabbage transplants were watered with dimethoate after planting for protection against small cabbage fly (Delia brassicae L.) each year. In 1993, the cabbage field was kept under a nonwowen polypropylene cover (Lutrasil $17 \mathrm{~g} \mathrm{~m}^{-2}$, Freudenberg \& Co., Germany ) between 26 May and 18 June in order to prevent damages by the
European tarnished plant bug (Lygus rugulipennis Poppius). In 1994, plant bug was controlled by applying permethrin once in June, and in 1995 permethrin and lambda-cyhalothrin were both applied once. Later during the growing period in 1993, both dimethoate and deltamethrin were applied twice against the small and large cabbage fly (Delia brassicae L. and Delia radicum L.). In 1994, deltamethrin was applied twice, and in 1995 permethrin once against cabbage flies. Weeds were controlled in 1993 and 1994 by applying propachlor 4-5 days after planting, but in 1995 rain delayed application until two weeks after planting.

\section{Carrot}

The subplots were $3 \mathrm{~m} \times 10 \mathrm{~m}$. The plant spacing between rows was $0.75 \mathrm{~m}$ and the target plant density was 60 plants per row metre (800 000 plants $\left.\mathrm{ha}^{-1}\right)$. Seeds were sown $1-1.5 \mathrm{~cm}$ deep by a pneumatic sowing machine (Caspardo SV260, Italy) at the beginning of May in 1993 and 1994 (Table 4). In 1995, carrots were sown by a manually propelled cup-disc planter (Nibex, Nibeverken AB, Sweden). In 1993, seeds were drilled in the middle of the ridge in double rows and in 1994 in double rows with no ridges. In 1995, seeds were sown in single rows with a planned density of 290000 plants ha-1 (Table 4).

In 1993, the plots were irrigated with $10 \mathrm{~mm}$ twice in May to improve plant establishment and once in July when plant-available water decreased rapidly according to the gypsum block measurements. In 1994, crops were irrigated five times in July and August (Table 3). In 1995, irrigation was applied twice in July.

Weeds were sprayed with metoxuron one month after sowing each year. In 1993, dimethoate and deltamethrin were first applied against European tarnished plant bug and carrot sucker (Trioza apicalis Förster) and later against carrot fly (Psila rosae F.), altogether four times. In 1994, plant bug and carrot sucker were controlled by permethrin four times, and carrot fly was controlled by permethrin and deltamethrin altogether four times. In 1995, plant bug, carrot sucker and carrot fly were controlled by permethrin and lamb- 


\section{AGRICULTURAL AND FOOD SCIENCE IN FINLAND}

Salo, T. Effects of nitrogen fertilizer on growth of cabbage, carrot and onion

da-cyhalothrin altogether five times. Although carrot fly was monitored by yellow traps, it damaged approximately $5 \%$ of the final yield in 1994

\section{Onion}

The subplots were $1.5 \mathrm{~m} \mathrm{x} 8 \mathrm{~m}$. The onion rows were $0.3 \mathrm{~m}$ apart and the spacing within rows was $0.075 \mathrm{~m}$. The edge rows of neighbouring subplots were $0.6 \mathrm{~m}$ apart. The sets, diameter $15-22 \mathrm{~mm}$, were planted by hand in May (Table 4). The onion rows were $5 \mathrm{~cm}$ to the side of the fertilizer band in the placement treatments (Fig. 1). Planting depth was approximately $3 \mathrm{~cm}$ and thus the vertical distance from the fertilizer band to the bottom of the onion set was approximately $7 \mathrm{~cm}$.

In 1993, the plants were irrigated twice with $5 \mathrm{~mm}$ of water to secure the start of growth after planting, and once with $10 \mathrm{~mm}$ in July. In 1994, the crops were irrigated five times (Table 3 ) according to the gypsum block measurements. In 1995, irrigation was applied three times in July.

Before planting, the onion sets were soaked for 15 minutes in $0.1 \%$ benomyl and $0.1 \%$ dimethoate solution for protection against grey mould (Botrytis cinerea Pers.) and onion fly (Delia antiqua Meigen), respectively. Weeds were sprayed with prometryn two weeks after onion planting. A mixture of metalaxyl and mancozeb was applied twice per growing season against downy mildew (Peronospora destructor Berk.). In 1993, two additional copper oxychloride applications were given in order to stop an observed downy mildew infection.

\subsection{Soil and plant measurements}

\subsubsection{Soil and root sampling}

\section{Cabbage}

In 1993, the soil was sampled for inorganic $\mathrm{N}$ on 24 June (30 days after planting = dap) from three replicated plots (Table 6). From the broadcast $250 \mathrm{~kg} \mathrm{ha}^{-1}$ and placed $250 \mathrm{~kg} \mathrm{ha}^{-1}$ treat- ments, additional depths of $0-10 \mathrm{~cm}$ and 10 $20 \mathrm{~cm}$ were sampled in order to assess vertical distribution of inorganic $\mathrm{N}$ and cabbage roots. Four subsamples per plot were taken a few centimetres to the side of the four sampled cabbage plants, and two subsamples between rows to assess the horizontal distribution of roots. All soil and root samples were taken using a core with 5 $\mathrm{cm}$ diameter. Individual subsamples were bulked and stored at $-18^{\circ} \mathrm{C}$ until laboratory analysis.

The second soil sampling was made on 27 July (63 dap, Table 6). Samples were taken both within (four subsamples) and between rows (two subsamples) to find out if there were horizontal differences in the distribution of soil inorganic $\mathrm{N}$ and cabbage roots. The third soil sampling was made after harvest, on 17 September (115 dap), in order to assess the residual amount of $\mathrm{N}$ after the cabbage crop. Eight subsamples were taken randomly from each plot.

In 1994, the first soil sampling was made on 8 July (38 dap, Table 6). One core sample was taken at a few centimetres distance from each cabbage plant sampled and these four core samples for each plot were bulked and stored at $-18^{\circ} \mathrm{C}$. From the treatment of placed $160 \mathrm{~kg} \mathrm{ha}^{-1}$, three separate core samples were taken from a line perpendicular to the row, so that the middle coring was at the location of the sampled cabbage plant and two corings were $5 \mathrm{~cm}$ to the side of the sampled plant (Fig. 1). These samples were taken from the location of two cabbage plants. This sampling was made to assess the horizontal and vertical distribution of soil inorganic $\mathrm{N}$ near the plants in the placement treatment.

The second soil sampling was made on 13 September (105 dap) in order to assess the amount of residual $\mathrm{N}$ in the soil after harvest. Eight subsamples were taken randomly from each plot.

\section{Carrot}

In 1993, the soil was sampled for inorganic $\mathrm{N}$ on 21 July (106 days after sowing = das, Table 6) from three replicated plots. Soil samples were taken from the location where the sampled car- 


\section{AGRICULTURAL AND FOOD SCIENCE IN FINLAND}

Vol. 2 (1999): 157-232.

Table 6. Dates, depths and locations of soil samplings.

\begin{tabular}{|c|c|c|c|c|}
\hline Cabbage & Date & Treatment & Depth $(\mathrm{cm})$ & Location \\
\hline \multirow[t]{3}{*}{1993} & 24 June (30 dap) & $\begin{array}{c}\text { 0, B\&P125, B\&P188 } \\
\text { B\&P250 }\end{array}$ & $\begin{array}{c}0-20-40 \\
0-10-20-40\end{array}$ & $\begin{array}{l}\text { plant row } \\
\text { plant row }\end{array}$ \\
\hline & 27 July (63 dap) & B\&P188 & $0-10-20-40-60$ & plant row, interrow \\
\hline & 17 September (115 dap) & 0, B125, B188, B250 & $0-25-60$ & interrow \\
\hline \multirow[t]{2}{*}{1994} & 8 July (38 dap) & $\begin{array}{l}\text { 0, B160 } \\
\text { P160 }\end{array}$ & $0-5-10-15-20-30-40$ & $\begin{array}{c}\text { plant row } \\
\text { plant row, fertilizer row }\end{array}$ \\
\hline & 13 September (105 dap) & $0, \mathrm{~B} \& \mathrm{P} 160$ & $0-25-60$ & interrow \\
\hline \multicolumn{5}{|l|}{ Carrot } \\
\hline \multirow[t]{2}{*}{1993} & 21 July (106 das) & $\begin{array}{c}\text { 0, B\&P30, B\&P70, } \\
\text { B\&P100 }\end{array}$ & $0-10-20-40-60$ & plant row \\
\hline & 15 October (164 das) & $0, \mathrm{~B} 100$ & $0-25-60$ & plant row \\
\hline 1994 & 14 October (161 das) & $0, \mathrm{~B} 100$ & $0-25-60$ & plant row \\
\hline \multicolumn{5}{|l|}{ Onion } \\
\hline \multirow[t]{3}{*}{1993} & 18 June (35 dap) & $\begin{array}{c}\text { 0, B\&P30, B\&P70 } \\
\text { B100 } \\
\text { P100 }\end{array}$ & $\begin{array}{c}0-25-40 \\
0-10-20-40 \\
0-10-20-40\end{array}$ & $\begin{array}{l}\text { plant row, interrow } \\
\text { plant row, interrow } \\
\text { plant row, fertilizer row, } \\
\text { non-fertilized interrow }\end{array}$ \\
\hline & 20 July (70 dap) & $\mathrm{B} \& \mathrm{P} 70$ & $0-10-20-30$ & plant row, interrow \\
\hline & 20 September (132 dap) & $0, \mathrm{~B} 100$ & $0-25-60$ & interrow \\
\hline \multirow[t]{2}{*}{1994} & 15 June (36 dap) & $\begin{array}{c}0 \\
\mathrm{~B} 100 \\
\mathrm{P} 100\end{array}$ & $\begin{array}{c}0-20-40 \\
0-5-10-15-20-30-40 \\
0-5-10-15-20-30-40\end{array}$ & $\begin{array}{c}\text { plant row } \\
\text { plant row } \\
\text { plant row, fertilizer row, } \\
\text { non-fertilized interrow }\end{array}$ \\
\hline & 9 September (122 dap) & $0, \mathrm{~B} 100$ & $0-25,25-60$ & interrow \\
\hline
\end{tabular}

dap $=$ days after planting

das $=$ days after sowing

$\mathrm{B}=$ Broadcast, $\mathrm{P}=$ Placement

rots were grown (Fig. 1). The soil samples were stored at $-18^{\circ} \mathrm{C}$ until laboratory analysis. The second soil sampling was made on 15 October (164 das) and six subsamples were taken ran- domly from each plot. In 1994, soils were sampled on 14 October (161 das, Table 6). The samples were treated and analyzed as in 1993. 


\section{AGRICULTURAL AND FOOD SCIENCE IN FINLAND}

Salo, T. Effects of nitrogen fertilizer on growth of cabbage, carrot and onion

\section{Onion}

In 1993, the experimental plots were sampled for inorganic $\mathrm{N}$ in soil on 15 June (35 dap, Table 6) from three replicated plots. Samples were taken both within (four subsamples) and between rows (two subsamples). From the broadcast $100 \mathrm{~kg} \mathrm{ha}^{-1}$ and placed $100 \mathrm{~kg} \mathrm{ha}^{-1}$ treatments three separate core samples were taken from a line perpendicular to the onion row, so that the middle coring was at the location of sampled onion plants and two corings were $5 \mathrm{~cm}$ to the side of the onion row (Fig 1). These samples were taken at depths of $0-10 \mathrm{~cm}$ and $10-20 \mathrm{~cm}$ and four locations per plot were sampled. These samples were used to assess the spatial distribution of soil inorganic $\mathrm{N}$ near the plants and the root lengths. The subsamples were bulked, ground manually to pass a 20 $\mathrm{mm}$ sieve in the laboratory and roots were separated from the soil samples. The soil was then stored at $-18^{\circ} \mathrm{C}$ until laboratory analysis.

The second soil sampling was made on 20 July (70 dap, Table 6). Roots and soil inorganic $\mathrm{N}$ were determined as at the first sampling. The third soil sampling was made on 20 September (132 dap, Table 6) from three replicated plots. Six subsamples were taken randomly from each plot.

In 1994, the first soil sampling was made on 15 June (36 dap, Table 6). From the placed 100 $\mathrm{kg} \mathrm{ha}^{-1}$ treatment three separate soil samples were taken from a line perpendicular to the onion row, so that the middle sample was at the location of the onion row (Fig 1). Four subsamples were taken per plot and bulked as a single sample.

The second soil sampling was made on 9 September (122 dap, Table 6) in order to assess the amount of residual $\mathrm{N}$ in the soil after harvest. Six subsamples were taken randomly from each plot.

\subsubsection{Plant sampling and final yield Cabbage}

In 1993, plant samples were taken on 22 June (28 dap), 19 July (55 dap), 10 August (78 dap) and 7 September (105 dap) which was the date of final harvest (Table 7). The date of final harvest was decided according to the target head weight, $1.5 \mathrm{~kg}$. Aerial parts of the cabbage plants were cut at ground level from the edges of the middle rows. Sampling locations were systematically ordered so that the same location was used for each plot, and it was checked that there were no missing plants in the vicinity of the sampled plants. Heads and leaves were cut and weighed separately at two latter samplings. Part of the stem was included in leaf weight measurements but excluded from dry matter and $\mathrm{N}$ determinations. The stem of the cultivar studied is short and should not much affect the measurements. To determine the dry matter content, samples were sliced and maximum $500 \mathrm{~g}$ of sample was dried to constant weight at $60^{\circ} \mathrm{C}$. For the estimation of the final yield, heads were cut from the two middle rows from the total row length of $12 \mathrm{~m}$. The heads were then weighed and their number was counted. The visible quality of the heads was good each year, and the few distorted or damaged heads were also included in the final yield.

In 1994 and 1995 plants were sampled four times during the growing period (Table 7). Plant samples and final yields in 1994 and 1995 were prepared and analyzed as in 1993.

\section{Carrot}

In 1993, plants were sampled on 21 July (78 das), 18 August (106 das) and 1 October (150 das) which was the date of final harvest (Table 7). The final harvest was scheduled as late as possible in order to benefit from the growth in September, as the cultivar studied maintained green leaves until October. Samplings were done systematically from the edges of the middle rows, the same location of each plot, and checking that the sampled plant stand was uniform to the remaining plot. The sampling methods were different in order to obtain a sufficient amount of plant material for analysis and to preserve an intact area for the final harvest. Carrot storage roots and shoots were sampled separately on all plots. The fresh weights of the shoots and the washed, airdried storage roots were recorded. 
AGRICULTURAL AND FOOD SCIENCE IN FINLAND

Vol. 2 (1999): 157-232.

Table 7. Sampling dates and areas.

\begin{tabular}{|c|c|c|c|c|c|}
\hline & Year & Date & Dap/Das & Plants/ sample & Area $\left(\mathrm{m}^{2}\right)$ \\
\hline \multicolumn{6}{|l|}{ Cabbage } \\
\hline & \multirow[t]{4}{*}{1993} & 22 June & 28 & 4 & 1 \\
\hline & & 19 July & 55 & 4 & 1 \\
\hline & & 10 August & 78 & 4 & 1 \\
\hline & & 7 September & 105 & 4 & 1 \\
\hline & \multirow[t]{4}{*}{1994} & 28 June & 29 & 4 & 1 \\
\hline & & 20 July & 50 & 4 & 1 \\
\hline & & 10 August & 70 & 4 & 1 \\
\hline & & 7 September & 99 & 4 & 1 \\
\hline & \multirow[t]{4}{*}{1995} & 19 July & 33 & 4 & 1 \\
\hline & & 2 August & 47 & 4 & 1 \\
\hline & & 22 August & 67 & 4 & 1 \\
\hline & & 3 October & 109 & 4 & 1 \\
\hline \multicolumn{6}{|l|}{ Carrot } \\
\hline & \multirow[t]{3}{*}{1993} & 21 July & 78 & 55 & 0.75 \\
\hline & & 18 August & 106 & 22 & 0.30 \\
\hline & & 1 October & 150 & 15 & 0.21 \\
\hline & \multirow[t]{3}{*}{1994} & 14 July & 69 & 24 & 0.30 \\
\hline & & 2 August & 88 & 24 & 0.30 \\
\hline & & 30 September & 147 & 15 & 0.19 \\
\hline & \multirow[t]{3}{*}{1995} & 2 August & 84 & 13 & 0.45 \\
\hline & & 22 August & 104 & 13 & 0.45 \\
\hline & & 6 October & 149 & 13 & 0.45 \\
\hline \multicolumn{6}{|l|}{ Onion } \\
\hline & \multirow[t]{4}{*}{1993} & 14 June & 34 & 21 & 0.36 \\
\hline & & 7 July & 57 & 11 & 0.30 \\
\hline & & 2 August & 83 & 10 & 0.28 \\
\hline & & 17 August & 98 & 20 & 0.57 \\
\hline & \multirow[t]{4}{*}{1994} & 14 June & 35 & 10 & 0.29 \\
\hline & & 4 July & 55 & 10 & 0.29 \\
\hline & & 27 July & 78 & 10 & 0.29 \\
\hline & & 23 August & 105 & 10 & 0.29 \\
\hline & \multirow[t]{4}{*}{1995} & 20 June & 21 & 10 & 0.32 \\
\hline & & 13 July & 44 & 10 & 0.32 \\
\hline & & 8 August & 70 & 10 & 0.32 \\
\hline & & 17 August & 79 & 10 & 0.32 \\
\hline
\end{tabular}

Dap/Das = days after planting or sowing

Then the storage roots were chopped by a food processor (Braun UK40, Braun, Germany) and a maximum of $500 \mathrm{~g}$ samples were dried to constant weight at $60^{\circ} \mathrm{C}$. For estimation of the final yield, carrot storage roots were collected from 12 ridge metres. The storage roots were weighted and this weight was considered as the final yield. Then the storage roots were partitioned 


\section{AGRICULTURAL AND FOOD SCIENCE IN FINLAND}

Salo, T. Effects of nitrogen fertilizer on growth of cabbage, carrot and onion

into the following classes by weight: $<50 \mathrm{~g}, 50-$ $250 \mathrm{~g},>250 \mathrm{~g}$, and distorted and damaged storage roots were separated. The weight and number of storage roots in each class were determined. The class of 50-250 g storage roots was considered as marketable yield.

In 1994 and 1995, plants were sampled three times during the growing period (Table 7). Plant samples and final yields in 1994 and 1995 were prepared and analyzed as in 1993.

\section{Onion}

In 1993, plants were sampled on 14 June (34 dap), 7 July (57 dap), 2 August (83 dap) and 17 August (98 dap) which was the date of final harvest (Table 7). Sampling locations, the edges of the middle rows, were systematically ordered so that the same location was used for each plot, and it was checked that the sampled plants grew at a plant density similar to the remaining plants. The sampling methods were different in order to obtain sufficient amount of plant material for analysis and to preserve an intact area for the final harvest. The foliage and bulbs were sampled separately from all plots. Foliage included leaf blades and sheaths. The fresh weights of the foliage and the washed, airdried bulbs were recorded. Then the bulbs were chopped by a food processor (Braun UK40, Braun, Germany) and samples of a maximum of $500 \mathrm{~g}$ were dried to constant weight at $60^{\circ} \mathrm{C}$. The final yield was collected when at least $70 \%$ of the shoots had fallen. Fertilized shoots fell first in both years, and non-fertilized shoots followed in a few days, after which the whole experiment was harvested. Leaves were removed in the field and bulbs were collected from the two middle rows from a length of 6 metres. Then these bulbs were allowed to dry for 2 months in a greenhouse at a temperature of about $30^{\circ} \mathrm{C}$. Then the onions were partitioned into the following classes by diameter: < $4.0 \mathrm{~cm}, 4.0-5.5,5.6-7.0$ and $>7.0 \mathrm{~cm}$. The bulbs were then weighed and the number of bulbs in each class was counted. There were only a few damaged bulbs, and they were included in the corresponding size class. The sum of all classes was considered as final yield.

In 1994 and 1995, plants were sampled four times (Table 7). In 1995, the yield was harvested on 29 August (91 dap), while the shoots were already fallen on 17 August. Plant samples and final yields in 1994 and 1995 were treated and analyzed as in 1993.

\subsubsection{Laboratory analysis}

\section{Plant samples}

Plant samples dried at $60^{\circ} \mathrm{C}$ were ground to pass a $1 \mathrm{~mm}$ sieve. Nitrogen in the plant material was measured by the macro-Kjeldahl method in which copper is used as a catalyst and potassium sulphate is used to raise the digestion temperature. After digestion, Kjeldahl-N was measured with a Kjeltec Auto 1030 Analyzer using alkaline distillation of $\mathrm{NH}_{3}$ and determination of $\mathrm{NH}_{4}$ by acidimetric titration (Tecator 1981).

As the recovery of nitrate- $\mathrm{N}$ by the Kjeldahl method is not complete, estimation of the portion of nitrate- $\mathrm{N}$ in plant $\mathrm{N}$ uptake was done from the first and second onion and cabbage samplings of 1993. Nitrate-N was measured from dry foliage samples with a nitrate-specific electrode (Orion 1983). At the first sampling of cabbage (28 dap), nitrate- $\mathrm{N}$ concentration averaged 2.9 $\mathrm{g} \mathrm{kg}^{-1} \mathrm{DM}$ and $9.5 \mathrm{~g} \mathrm{~kg}^{-1} \mathrm{DM}$ in non-fertilized and $250 \mathrm{~kg} \mathrm{ha}^{-1}$ fertilized treatments, respectively. At the second sampling (55 dap), cabbage nitrate- $\mathrm{N}$ concentrations were $0.1 \mathrm{~g} \mathrm{~kg}^{-1}, 4.6 \mathrm{~g}$ $\mathrm{kg}^{-1}$ and $6.4 \mathrm{~g} \mathrm{~kg}^{-1}$ in the non-fertilized, broadcast $250 \mathrm{~kg} \mathrm{ha}^{-1}$ and placed $250 \mathrm{~kg} \mathrm{ha}^{-1}$ treatments, respectively. Cabbage nitrate- $\mathrm{N}$ measured by a nitrate-selective electrode was at the first sampling a maximum $17 \%$ and at the second sampling $10-15 \%$ of the $\mathrm{N}$ measured by the Kjeldahl method. Although nitrate-N concentration decreases during the growing period of cabbage (e.g. Riley and Guttormsen 1993a), during the first half of the growing period nitrate- $\mathrm{N}$ can have about $10 \%$ influence on $\mathrm{N}$ uptake.

Onion nitrate- $\mathrm{N}$ concentration varied 34 days after planting from $0.3 \mathrm{~g} \mathrm{~kg}^{-1} \mathrm{DM}$ for the non- 


\section{AGRICULTURAL AND FOOD SCIENCE IN FINLAND}

Vol. 2 (1999): 157-232.

fertilized treatment to $0.9 \mathrm{~g} \mathrm{~kg}^{-1} \mathrm{DM}$ in the broadcast treatments and $1.6 \mathrm{~g} \mathrm{~kg}^{-1} \mathrm{DM}$ in the placement treatments. At the second sampling (57 dap), onion nitrate- $\mathrm{N}$ concentrations varied from $0.2 \mathrm{~g} \mathrm{~kg}^{-1} \mathrm{DM}$ for the non-fertilized treatments to $0.5 \mathrm{~g} \mathrm{~kg}^{-1} \mathrm{DM}$ in the broadcast treatments and $0.9 \mathrm{~g} \mathrm{~kg}^{-1} \mathrm{DM}$ in the placement treatments. Onion nitrate- $\mathrm{N}$ measured by a nitrate-selective electrode was between $0.7 \%$ and $4.5 \%$ of the $\mathrm{N}$ measured by the Kjeldahl method. As nitrate-N concentration decreases later during the growing period (Greenwood et al. 1992), it is possible to assume that the nitrate- $\mathrm{N}$ content of onion foliage did not much affect the calculated plant $\mathrm{N}$ uptakes.

Regarding carrot, Evers (1989) determined that carrot shoot nitrate-N concentration decreased from 4-5 $\mathrm{g} \mathrm{kg}^{-1} \mathrm{DM}$ (66-75 das) to $0.5-$ $1.5 \mathrm{~g} \mathrm{~kg}^{-1} \mathrm{DM}$ at harvest (116-121 das). Nitrate$\mathrm{N}$ content was at first approximately $15 \%$ of the Kjeldahl-N and at harvest 2-8\%. Thus actual $\mathrm{N}$ uptake can be underestimated at the first carrot sampling but later the underestimation is decreased.

\section{Soil samples}

Soil samples were allowed to thaw at $+4^{\circ} \mathrm{C}$ and $100 \mathrm{~g}$ of soil was extracted with $250 \mathrm{ml} 2 \mathrm{M} \mathrm{KCl}$ for two hours (Esala 1995) and analyzed with a Skalar AutoAnalyser for $\mathrm{NH}_{4}^{+}-\mathrm{N}$ and $\mathrm{NO}_{3}{ }^{-}{ }_{-} \mathrm{N}$ (Krom 1980, Greenberg et al. 1980). The dry matter content of the soil was determined by drying $40 \mathrm{~g}$ moist soil overnight at $105^{\circ} \mathrm{C}$.

\section{Root samples}

After taking $140 \mathrm{~g}$ of soil for soil inorganic $\mathrm{N}$ determination, soil samples from the first and second soil sampling for cabbage and the first soil sampling for carrot in 1993 were soaked in a solution of $0.015 \mathrm{M} \mathrm{NaOH}$ to disperse the clay and to wash the fibrous roots. The soil was washed from the soil samples with a hydropneumatic elutriatior (Smucker et al. 1982) which separated any organic material which was less dense than the mineral fraction of the soil. Or- ganic debris associated with the root samples was manually removed from the root samples. Fibrous roots were dyed with Malachite green oxalate and laid in a water bath. At this stage, samples from different replicates were bulked and fibrous roots were photocopied for each treatment. The photocopies were analyzed by an image analyzer (Olympus CUE-2, Japan). The area of fibrous roots in the photocopy was recorded from the image analyzer data. The average width of the fibrous roots in a sample was estimated from the photocopy and then the fibrous root length was calculated dividing the measured fibrous root area by the estimated fibrous root width.

Onion roots from the first and second soil sampling in 1993 were placed in a flat glass dish containing water. A $1 \mathrm{~cm}$ grid was placed under the dish and the number of intersections between roots and the vertical and horizontal lines was calculated. The root length of the sample was calculated using the equation:

Root length $=11 / 14 \mathrm{x}$ number of intersections $\mathrm{x}$ grid unit

This method is described e.g. in Böhm (1979). Roots that were attached to the sampled onions were cut and their length was measured with a ruler. The length of these roots was included in the root length of the soil layer 0-10 $\mathrm{cm}$ from the location of the onion row. Data on root length is presented as $\mathrm{cm}$ per kilogram of dry soil. Carrot root length is additionally presented as $\mathrm{cm}$ per $\mathrm{cm}^{2}$ of soil surface in order to compare root lengths between layers of different depths.

\subsubsection{Apparent recovery of fertilizer nitrogen}

The apparent recovery of fertilizer- $\mathrm{N}$ in aboveground plant was calculated as the difference in above-ground plant $\mathrm{N}$ uptake between fertilized and non-fertilized plots, and divided by the amount of fertilizer applied. 


\section{AGRICULTURAL AND FOOD SCIENCE IN FINLAND}

Salo, T. Effects of nitrogen fertilizer on growth of cabbage, carrot and onion

\subsection{Statistical analysis}

Plant fresh weight, dry matter content and Kjeldahl-N were determined, and plant dry weight and plant $\mathrm{N}$ uptake were calculated from these measurements. For each crop, plant dry weight included the following plant organs, cabbage head, leaves and small part of the stem, carrot storage roots and leaves and onion bulbs and foliage. The sampling data for cabbage and onion were converted to kilograms per hectare by multiplying the sampling results by the planting density. Only final yields and the numbers of cabbage heads and onion bulbs in the final yield were multiplied according to the actual plant density. The sampling data for carrot was converted to kilograms per hectare by multiplying the sampling results by the ratio of row length in one hectare (13 $\left.333 \mathrm{~m} \mathrm{ha}^{-1}\right)$ to the sampled row length. The sample of 15 carrots at harvest in 1993 and 1994 was multiplied by the actual plant density obtained from the 12 row metres harvested. The final yield and the number of carrots in the final yield were also multiplied by the ratio of row length in one hectare to the harvested row length. In addition, a sample yield was calculated from the plants in the last sampling in order to compare the yield of samplings to the final yield that contains more spatial variability.

Plant dry matter accumulation, dry matter content, $\mathrm{N}$ concentration and $\mathrm{N}$ uptake of different plant organs were analyzed separately at each sampling by the SAS MIXED procedure (Littell et al. 1996). First the non-fertilized treatment was tested separately against broadcast or placed $\mathrm{N}$ rates using ANOVA for randomized complete block design.

After this the non-fertilized treatment was excluded from the data, and the mixed model for split-plot design was used to test differences between $\mathrm{N}$ rates or application methods and interactions between them (Littell et al. 1996). The model was as follows:

$$
\mathrm{Y}_{\mathrm{ijk}}=\mu+\mathrm{B}_{\mathrm{k}}+\mathrm{A}_{\mathrm{i}}+\mathrm{AB}_{\mathrm{ik}}+\mathrm{C}_{\mathrm{j}}+\mathrm{AC}_{\mathrm{ij}}+\varepsilon_{\mathrm{ijk}}
$$

where $\mathrm{Y}_{\mathrm{ijk}}$ is the response from $\mathrm{jth}$ application method on ith $\mathrm{N}$ rate on kth block. The quantities $\mu, A_{i}, C_{j}$ and $A_{i j}$ are fixed parameters. The $B_{k}$ terms are random effects of block that are assumed to be normally and independently distributed with mean 0 and variance $\sigma_{B}^{2}$. Furthermore, the interaction terms, $\mathrm{AB}_{\mathrm{ik}}$, as well as the error terms, $\varepsilon_{\mathrm{ijk}}$, are considered random effects with $\mathrm{AB}_{\mathrm{ik}} \sim \operatorname{NID}\left(0, \sigma_{A B}^{2}\right)$ and $\varepsilon_{\mathrm{ijk}} \sim \operatorname{NID}(0$, $\sigma_{\varepsilon}^{2}$ ), respectively. $\mathrm{A}_{\mathrm{i}}$ was used as error terms for $B_{k}$ and $e_{i j k}$ was used as error terms for $C_{j}$ and $\mathrm{AC}_{\mathrm{ij}}$. Assumptions of the model were checked by using graphical methods: box plot for normality of errors and plots of residuals for constancy of error variance.

Main and subplot effects with $\mathrm{F}$ test probability values above 0.05 were considered nonsignificant, and probability values above 0.10 are not presented. If there was an interaction $\mathrm{P}<0.10$ between $\mathrm{N}$ rates and application methods, contrasts were calculated to test differences between means of application methods at the same $\mathrm{N}$ rate and between means of $\mathrm{N}$ rates with the same application method using Satterthwaite's approximation to correct degrees of freedom (Littell et al. 1996). If there was a main plot effect $\mathrm{P}<0.05$, contrasts of all means of $\mathrm{N}$ rates were estimated, and their difference from zero was tested with the $t$ test.

The standard error of the mean was calculated for the soil samples, and they were treated in a descriptive way, without any statistical test between the treatments. The root lengths of onion were tested separately for each depth using the mixed model for split-plot design, with treatment as a main plot and sampling location as a subplot. It was not possible to test the root lengths of cabbage and carrot as the replicates were bulked during the analysis.

Linear regression was calculated between plant $\mathrm{N}$ uptake and sample yield or dry matter accumulation, both determined from the last sampling. The regression was assumed to be linear as the $\mathrm{N}$ rates were low or moderate and the intercept was fixed at the origin. The plant $\mathrm{N}$ concentration was related to the dry matter accumulation of all samplings using the equation 


\section{AGRICULTURAL AND FOOD SCIENCE IN FINLAND}

Vol. 2 (1999): 157-232.

of Greenwood and Draycott (1989):

Critical N\% $=1.35 \times\left(1+B \times e^{-0.26 \times \text { Dry Weight }}\right)$

where $\mathrm{B}=$ species dependent coefficient, and dry weight is presented as $\mathrm{tha}^{-1}$.

Coefficient B was estimated separately for non-fertilized and fertilized plots with the NLINprocedure of SAS software using Gauss-Newton iteration for parameter estimation (Freund and Littell 1991). In addition, the 95\% confidence interval for the estimated coefficient B was calculated. While discussing the above regression analysis, we must have a certain doubt of the results, as individual samples are dependent on each other due to the treatments and year and also sampling date in the non-linear regression.
Altogether three observations were excluded from the analysis of $\mathrm{N}$ concentration and $\mathrm{N}$ uptake. One onion sample from the third sampling in 1993 was lost before $\mathrm{N}$ analysis. Two $\mathrm{N}$ concentrations from the second sampling of cabbage in 1993 were considered outliers as their $\mathrm{N}$ concentrations were two and three times higher than the $\mathrm{N}$ concentrations of their replicates. From the first soil sampling of cabbage in 1993, all samples from the fourth replicate and two 20 $40 \mathrm{~cm}$ samples from the placed $250 \mathrm{~kg} \mathrm{ha}^{-1}$ were lost during storage. Also three $20-40 \mathrm{~cm}$ soil samples from the first sampling of onion in 1993 were lost. Otherwise there were no missing observations.

\section{Results}

\subsection{Inorganic nitrogen in soil}

\section{Cabbage}

In June 1993 (30 dap), most of the $\mathrm{N}$ was in the $10 \mathrm{~cm}$ top layer in the plots where the fertilizer was broadcast and in the 10-20 cm layer in the plots where the fertilizer was band-placed (Table 8). The measured $\mathrm{N}$ contents were higher than $\mathrm{N}$ fertilization, probably due to the measurement inaccuracy caused by the small number of subsamples. At the end of July (63 dap), soil inorganic $\mathrm{N}$ had decreased to quite low values. There was clearly more $\mathrm{N}$ in the row than in the interrow area in plots with band placement, whereas $\mathrm{N}$ was divided evenly in plots with broadcast fertilizer. After harvest (115 dap), the amount of soil inorganic $\mathrm{N}$ was rather low. There was less than $20 \mathrm{~kg} \mathrm{ha}^{-1} \mathrm{~N}$ in the $0-60 \mathrm{~cm}$ layer, even in the broadcast $250 \mathrm{~kg} \mathrm{ha}^{-1}$ treatment.

In July 1994 (38 dap), samples taken from the $160 \mathrm{~kg} \mathrm{ha}^{-1}$ fertilized plots indicated that most of the $\mathrm{N}$ was in the $0-5 \mathrm{~cm}$ top layer in plots with broadcast fertilizer and in the $10-15 \mathrm{~cm}$ layer in plots with placed fertilizer (Table 9). Horizontal distribution was also clear in plots with placed fertilizer. In these plots, samples taken with a $5 \mathrm{~cm}$ horizontal distance of each other contained 190, 301 and $139 \mathrm{~kg} \mathrm{ha}^{-1} \mathrm{~N}$ in the 0 $20 \mathrm{~cm}$ layer in the locations of the plant row and two fertilizer rows, respectively. The small amount of $\mathrm{N}$ in one of the fertilizer rows indicates that another fertilizer band was actually less than $5 \mathrm{~cm}$ to the side of the cabbage row. After harvest (105 dap), the amount of soil inorganic $\mathrm{N}$ was again rather low. There was not more than 20 to $24 \mathrm{~kg} \mathrm{ha}^{-1} \mathrm{~N}$ in the $0-60 \mathrm{~cm}$ layer of the broadcast or placed $160 \mathrm{~kg} \mathrm{ha}^{-1}$ treatments.

\section{Carrot}

In July 1993 (106 das), on average 65\% and $53 \%$ of the soil inorganic $\mathrm{N}$ contained in the 0 $20 \mathrm{~cm}$ layer was at the depth of $0-10 \mathrm{~cm}$ after $\mathrm{N}$ was broadcast and placed, respectively (Table 10). Thus it seems that when $\mathrm{N}$ was broadcast and the ridge was formed, more inorganic $\mathrm{N}$ was distributed in the top soil. The inorganic $\mathrm{N}$ in 


\section{AGRICULTURAL AND FOOD SCIENCE IN FINLAND}

Salo, T. Effects of nitrogen fertilizer on growth of cabbage, carrot and onion

Table 8. Effect of $\mathrm{N}$ rate and application method on the soil inorganic $\mathrm{N}\left(\mathrm{NH}_{4}-\mathrm{N}+\mathrm{NO}_{3}-\mathrm{N}\right)$ contents in cabbage field in 1993. Standard error of the mean is in parentheses after the mean value.

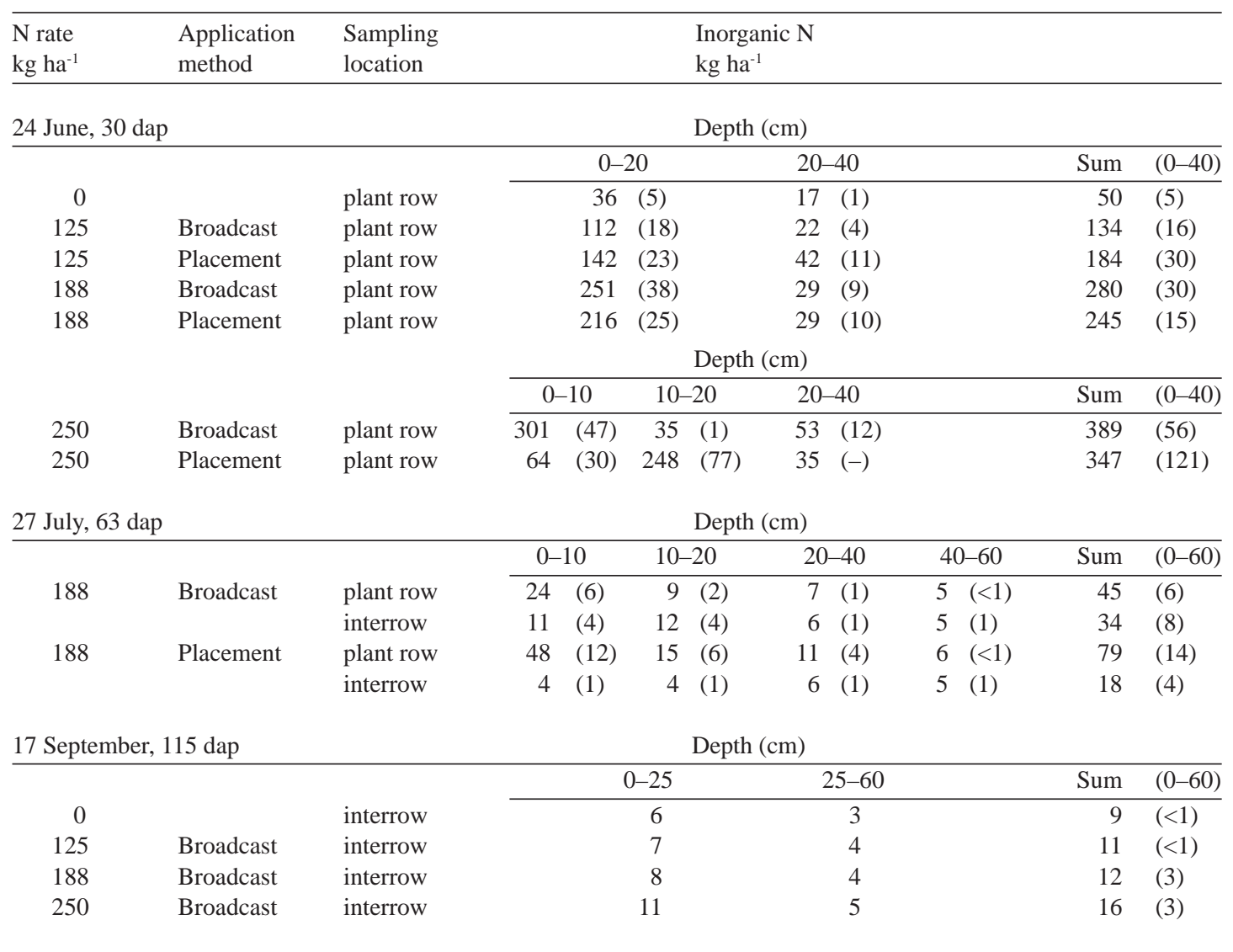

dap $=$ days after planting

the soil after harvest was less than $40 \mathrm{~kg} \mathrm{ha}^{-1}$, in both years (Table 10).

\section{Onion}

In June 1993 (35 dap), the original location of the fertilizer band still contained twice as much $\mathrm{N}$ as the location of the onion row (Table 11). In the broadcast treatments, $\mathrm{N}$ was fairly evenly distributed between row and interrow areas. The interrow $\mathrm{N}$ contents of the placed $30 \mathrm{~kg} \mathrm{ha}^{-1}$ and placed $70 \mathrm{~kg} \mathrm{ha}^{-1}$ treatments are high because the $\mathrm{N}$ band was located $5 \mathrm{~cm}$ to the side of the onion row and thus the distance of the interrow samples was only $5-10 \mathrm{~cm}$ from the fertilizer band. It is not clear why the $\mathrm{N}$ content in the broadcast $100 \mathrm{~kg} \mathrm{ha}^{-1}$ treatment was at the same level as the $\mathrm{N}$ content in the broadcast $70 \mathrm{~kg} \mathrm{ha}^{-1}$ treatment. One reason could be the different sampling depths while according to the 1994 results, broadcast $\mathrm{N}$ was mainly in the $0-5 \mathrm{~cm}$ soil layer. Sampling of the 0-20 layer, when most of the $\mathrm{N}$ was in the $5 \mathrm{~cm}$ layer, could give rather heterogeneous material for laboratory analysis. This can also be noted from the high standard errors of plant row and interrow means, 21 and $32 \mathrm{~kg} \mathrm{ha}^{-1}$ in the $0-20 \mathrm{~cm}$ layer of broadcast 70 $\mathrm{kg} \mathrm{ha}^{-1}$ (Table 11). 


\section{AGRICULTURAL AND FOOD SCIENCE IN FINLAND}

Vol. 2 (1999): 157-232.

Table 9. Effect of $\mathrm{N}$ rate and application method on soil inorganic $\mathrm{N}\left(\mathrm{NH}_{4}-\mathrm{N}+\mathrm{NO}_{3}-\mathrm{N}\right)$ contents in cabbage field in 1994. Standard error of the mean is in parentheses after the mean value.

\begin{tabular}{|c|c|c|c|c|c|c|c|c|c|}
\hline $\begin{array}{l}\mathrm{N} \text { rate } \\
\mathrm{kg} \mathrm{ha}^{-1}\end{array}$ & $\begin{array}{l}\text { Application } \\
\text { method }\end{array}$ & $\begin{array}{l}\text { Sampling } \\
\text { location }\end{array}$ & & & & $\begin{array}{l}\text { organic } \Gamma \\
\mathrm{kg} \mathrm{ha}^{-1}\end{array}$ & & & \\
\hline 8 July, 3 & & & & & & epth (cm) & & & \\
\hline & & & $0-5$ & $5-10$ & $10-15$ & $15-20$ & $20-30$ & $30-40$ & Sum $(0-40)$ \\
\hline 0 & & plant row & $19(5)$ & $7(1)$ & $8(1)$ & 7 (1) & $14(1)$ & 7 (1) & $62(6)$ \\
\hline 160 & Broadcast & plant row & $100(10)$ & $38(1)$ & $25(2)$ & $15(2)$ & $24(5)$ & $13(3)$ & 216 (14) \\
\hline 160 & Placement & fertilizer row & $14(1)$ & 48 (3) & 159 (12) & $80(7)$ & & & $337^{*}(22)$ \\
\hline & Placement & plant row & $15(2)$ & $35(8)$ & $93(21)$ & $46(7)$ & $26(4)$ & 9 (2) & 225 (28) \\
\hline & Placement & fertilizer row & 15 (1) & $24(7)$ & $58(28)$ & 42 (14) & & & $175^{*}(54)$ \\
\hline 13 Septe & er, 105 dap & & & & & epth $(\mathrm{cm})$ & & & \\
\hline & & & & $0-25$ & & $25-$ & & & Sum $(0-60)$ \\
\hline 0 & & interrow & & 11 (1) & & 6 & & & 17 (1) \\
\hline 160 & Broadcast & interrow & & $13(1)$ & & 11 & & & 24 (2) \\
\hline 160 & Placement & interrow & & $11(1)$ & & 9 & & & $20 \quad(1)$ \\
\hline
\end{tabular}

* Sum of $0-40 \mathrm{~cm}$ is calculated assuming the content of soil inorganic $\mathrm{N}$ at the depth of $20-40 \mathrm{~cm}$ of each location to be the same as in the location of plant row.

dap $=$ days after planting

Table 10. Effect of $\mathrm{N}$ rate and application method on soil inorganic $\mathrm{N}\left(\mathrm{NH}_{4}-\mathrm{N}+\mathrm{NO}_{3}-\mathrm{N}\right)$ contents in carrot field in $1993-$ 1994. Standard error of the mean is in parentheses after the mean value.

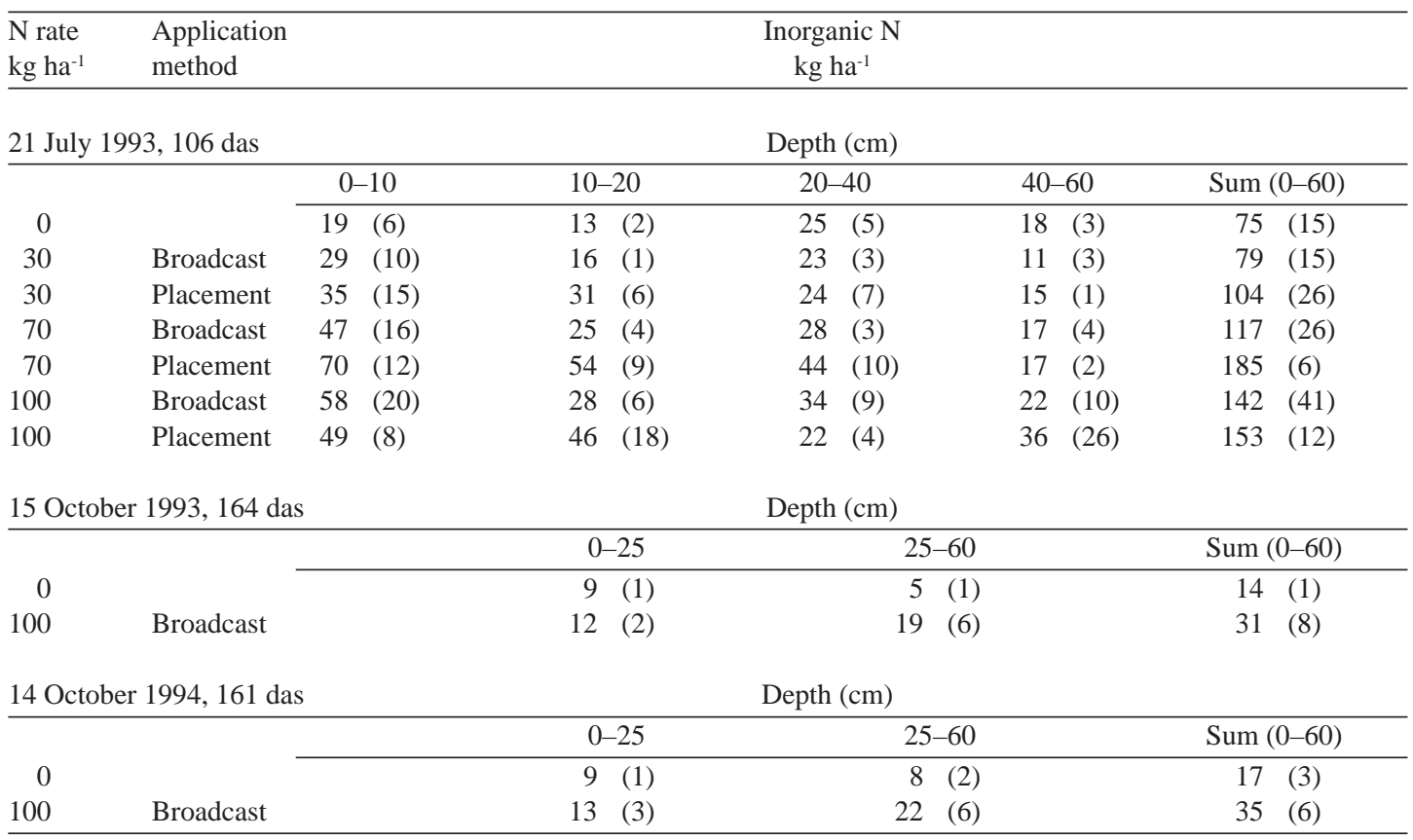

das $=$ days after sowing 


\section{AGRICULTURAL AND FOOD SCIENCE IN FINLAND}

\section{Salo, T. Effects of nitrogen fertilizer on growth of cabbage, carrot and onion}

Table 11. Effect of $\mathrm{N}$ rate and application method on the soil inorganic nitrogen $\left(\mathrm{NH}_{4}-\mathrm{N}+\mathrm{NO}_{3}-\mathrm{N}\right)$ contents in onion field in 1993. Standard error of the mean is in parentheses after the mean value.

\begin{tabular}{|c|c|c|c|c|c|c|}
\hline $\begin{array}{l}\mathrm{N} \text { rate } \\
\mathrm{kg} \mathrm{ha}^{-1}\end{array}$ & $\begin{array}{l}\text { Application } \\
\text { method }\end{array}$ & $\begin{array}{l}\text { Sampling } \\
\text { location }\end{array}$ & & $\begin{array}{l}\text { Inorganic N } \\
\mathrm{kg} \mathrm{ha}^{-1}\end{array}$ & & \\
\hline \multicolumn{3}{|c|}{18 June, 35 dap } & \multicolumn{3}{|c|}{ Depth (cm) } & \\
\hline \multirow{3}{*}{0} & & & \multicolumn{2}{|c|}{$0-20$} & $20-40$ & Sum $(0-40)$ \\
\hline & & plant row & 38 & (9) & $13 \quad(2)$ & $51(8)$ \\
\hline & & interrow & 24 & (4) & $16 \quad$ (4) & $40 \quad(1)$ \\
\hline \multirow[t]{2}{*}{30} & Broadcast & plant row & 37 & (6) & $28 \quad(5)$ & 65 (10) \\
\hline & Broadcast & interrow & 44 & (11) & $28 \quad(5)$ & 72 (14) \\
\hline \multirow[t]{2}{*}{30} & Placement & plant row & 109 & (1) & $24 \quad(3)$ & 136 (14) \\
\hline & Placement & interrow & 64 & (15) & $23 \quad(5)$ & 87 (11) \\
\hline \multirow[t]{2}{*}{70} & Broadcast & plant row & 102 & (21) & $35 \quad(16)$ & 137 (14) \\
\hline & Broadcast & interrow & 82 & (32) & $30 \quad(8)$ & 112 (30) \\
\hline \multirow[t]{4}{*}{70} & Placement & plant row & 167 & (13) & $36 \quad(15)$ & 203 (26) \\
\hline & Placement & interrow & 69 & (9) & $18 \quad(3)$ & $88(6)$ \\
\hline & & & \multicolumn{3}{|c|}{ Depth $(\mathrm{cm})$} & \\
\hline & & & $0-10$ & $10-20$ & $20-40$ & Sum $(0-40)$ \\
\hline \multirow[t]{3}{*}{100} & Broadcast & interrow & $75 \quad(9)$ & $19 \quad(3)$ & & $116^{*}(12)$ \\
\hline & Broadcast & plant row & $44 \quad(6)$ & $18 \quad(3)$ & $24 \quad(2)$ & $85 \quad(8)$ \\
\hline & Broadcast & interrow & $80 \quad(5)$ & $18 \quad(1)$ & & $121^{*}(7)$ \\
\hline \multirow[t]{3}{*}{100} & Placement & fertilizer row & $215 \quad(20)$ & 68 (13) & & $302^{*}$ (19) \\
\hline & Placement & plant row & $104 \quad(13)$ & $43 \quad(10)$ & $18 \quad(3)$ & $166 \quad(13)$ \\
\hline & Placement & $\begin{array}{l}\text { nonfertilized } \\
\text { interrow }\end{array}$ & 17 (1) & $16 \quad(2)$ & & $53^{*}(3)$ \\
\hline \multicolumn{3}{|c|}{20 July, 70 dap } & \multicolumn{3}{|c|}{ Depth $(\mathrm{cm})$} & \\
\hline \multirow{3}{*}{70} & & & $0-10$ & $10-20$ & $20-30$ & Sum $(0-30)$ \\
\hline & Broadcast & plant row & 21 (3) & $\begin{array}{ll}6 & (2)\end{array}$ & $8 \quad(1)$ & $35(1)$ \\
\hline & Broadcast & interrow & $34 \quad(13)$ & 9 (1) & $10 \quad(2)$ & 53 (13) \\
\hline \multirow[t]{2}{*}{70} & Placement & plant row & 12 (1) & 12 (1) & 7 (1) & 31 (2) \\
\hline & Placement & interrow & $12(2)$ & $13 \quad(2)$ & $7 \quad(1)$ & $32(2)$ \\
\hline \multicolumn{3}{|c|}{20 September, 132 dap } & \multicolumn{3}{|c|}{ Depth $(\mathrm{cm})$} & \\
\hline & & & $0-25$ & & $25-60$ & Sum $(0-60)$ \\
\hline 0 & & interrow & $\begin{array}{ll}4 \quad(<1) \\
\end{array}$ & & $4 \quad(1)$ & $8(1)$ \\
\hline 100 & Broadcast & interrow & $3(1)$ & & $5 \quad(2)$ & $8(2)$ \\
\hline
\end{tabular}

* Sum of $0-40 \mathrm{~cm}$ is calculated assuming the content of soil inorganic $\mathrm{N}$ at the depth of $20-40 \mathrm{~cm}$ of each location to be the same as in the location of plant row.

dap $=$ days after planting

In 1993, soil inorganic $\mathrm{N}$ contents had fallen to $30 \mathrm{~kg} \mathrm{ha}^{-1}$ in the placement treatments and approximately $45 \mathrm{~kg} \mathrm{ha}^{-1}$ in the broadcast treatments in the $0-30 \mathrm{~cm}$ layer by July (70 dap). After harvest in 1993, soil inorganic $\mathrm{N}$ contents were below $10 \mathrm{~kg} \mathrm{ha}^{-1}$ in the $0-60 \mathrm{~cm}$ layer.
In June 1994 (36 dap), the vertical distribution of $\mathrm{N}$ was different between the treatments. Most of the $\mathrm{N}$ in the placed $100 \mathrm{~kg} \mathrm{ha}^{-1}$ treatment was at the depth of 5-10 cm (Table 12). In the broadcast $100 \mathrm{~kg} \mathrm{ha}^{-1}$ treatment most of the $\mathrm{N}$ was at the depth of $0-5 \mathrm{~cm}$. At the original 


\section{AGRICULTURAL AND FOOD SCIENCE IN FINLAND}

Vol. 2 (1999): 157-232.

Table 12. Effect of $\mathrm{N}$ rate and application method on the soil inorganic nitrogen $\left(\mathrm{NH}_{4}-\mathrm{N}+\mathrm{NO}_{3}-\mathrm{N}\right)$ contents in onion field in 1994. Standard error of the mean is in parentheses after the mean value.

\begin{tabular}{|c|c|c|c|c|c|c|c|c|c|}
\hline $\begin{array}{l}\mathrm{N} \text { rate } \\
\mathrm{kg} \mathrm{ha}^{-1}\end{array}$ & $\begin{array}{l}\text { Application } \\
\text { method }\end{array}$ & $\begin{array}{l}\text { Sampling } \\
\text { location }\end{array}$ & & & & $\begin{array}{l}\text { organic N } \\
\text { ha }^{-1}\end{array}$ & & & \\
\hline 15 June & dap & & & & & pth $(\mathrm{cm})$ & & & \\
\hline & & & & $0-20$ & & & 20 & & Sum $(0-40)$ \\
\hline 0 & & plant row & & $33(4$ & & & 26 & & $59 \quad(5)$ \\
\hline & & & & & & pth $(\mathrm{cm})$ & & & \\
\hline & & & $0-5$ & $5-10$ & $10-15$ & $15-20$ & $20-30$ & $30-40$ & Sum $(0-40)$ \\
\hline 100 & Broadcast & plant row & $48 \quad(7)$ & $11(2)$ & $7(1)$ & $9(2)$ & $29(6)$ & 18 (3) & $122(10)$ \\
\hline 100 & Placement & fertilizer row & $51 \quad(17)$ & $84(15)$ & $39(9)$ & $12(3)$ & & & $215^{*}(30)$ \\
\hline & & plant row & $30(8)$ & 77 (11) & 40 (12) & $15(3)$ & $16(1)$ & $12(2)$ & $190 \quad(16)$ \\
\hline & & $\begin{array}{l}\text { nonfertilized } \\
\text { interrow }\end{array}$ & $14(2)$ & $8(1)$ & $8(1)$ & $8(1)$ & & & $67^{*}(6)$ \\
\hline 9 Septe & $r, 122$ dap & & & & & epth $(\mathrm{cm})$ & & & \\
\hline & & & & $0-25$ & & & $25-60$ & & Sum $(0-60)$ \\
\hline 0 & & interrow & & $17(2)$ & & & $27(5)$ & & $44(5)$ \\
\hline 100 & Broadcast & interrow & & 37 (4) & & & $43(6)$ & & $80(8)$ \\
\hline
\end{tabular}

* Sum of $0-40 \mathrm{~cm}$ is calculated assuming the content of soil inorganic $\mathrm{N}$ at the depth of $20-40 \mathrm{~cm}$ of each location to be the same as in the location of plant row.

dap $=$ days after planting

location of the fertilizer band there was $135 \mathrm{~kg}$ $\mathrm{ha}^{-1} \mathrm{~N}$ at the depth of $0-10 \mathrm{~cm}$ and at the location of the onion row $107 \mathrm{~kg} \mathrm{ha}^{-1}$ in June 1994. After harvest there was $36 \mathrm{~kg} \mathrm{ha}^{-1}$ less $\mathrm{N}$ in the 0-60 cm layer of the non-fertilized plots than in the broadcast $100 \mathrm{~kg} \mathrm{ha}^{-1}$ plots.

\subsection{Plant growth}

\subsubsection{Root length}

\section{Cabbage}

One month after planting (30 dap), the fibrous root length was similar in the broadcast and placed $250 \mathrm{~kg} \mathrm{ha}^{-1}$ treatments. Most of the fibrous roots were at the depth of $0-10 \mathrm{~cm}$ below the plant row and with practically no fibrous roots below $20 \mathrm{~cm}$ and between rows (Fig. 2). Two months after planting (63 dap), the length of fibrous roots was similar to that in the first sampling at the depths of $0-10 \mathrm{~cm}$ and $10-20$ $\mathrm{cm}$ (Fig. 2). In addition, there were fibrous roots at the depths of $20-30 \mathrm{~cm}$ and $30-40 \mathrm{~cm}$ in both treatments. Fibrous root length was higher between rows in the broadcast $188 \mathrm{~kg} \mathrm{ha}^{-1}$ treatment than in the placed $188 \mathrm{~kg} \mathrm{ha}^{-1}$ treatment.

\section{Carrot}

There were slightly less fibrous roots at the depth of 0-10 than $10-20 \mathrm{~cm}$ at the end of July (106 das, Fig. 3). The length of fibrous roots varied from 150 to $250 \mathrm{~cm} \mathrm{~kg}^{-1}$ dry soil and from 150 to $400 \mathrm{~cm} \mathrm{~kg}^{-1}$ dry soil at depths of $0-10$ and $10-20 \mathrm{~cm}$, respectively. The amount of fibrous roots was still low at depths of $20-40 \mathrm{~cm}$ and $40-60 \mathrm{~cm}$. 
Salo, T. Effects of nitrogen fertilizer on growth of cabbage, carrot and onion

30 dap

$250 \mathrm{~kg} / \mathrm{ha}$ Broadcast Depth (cm)

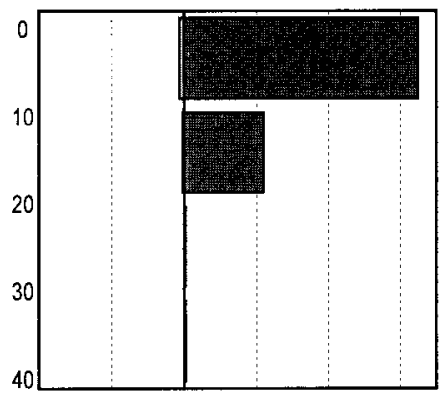

$250 \mathrm{~kg} / \mathrm{ha}$ Placement

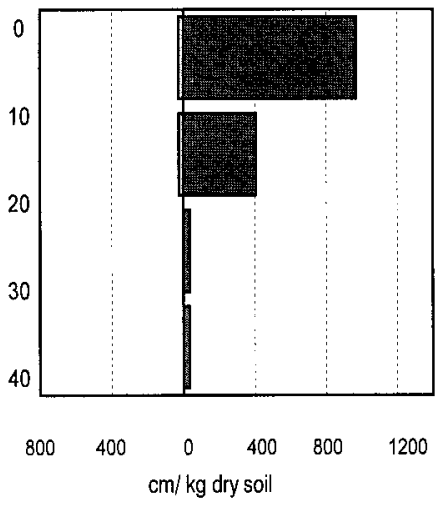

Interrow

Plant row
63 dap

$188 \mathrm{~kg} / \mathrm{ha}$ Broadcast

Depth (cm)

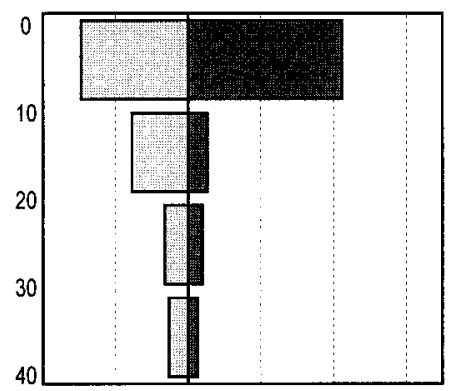

188 kg/ha Placement

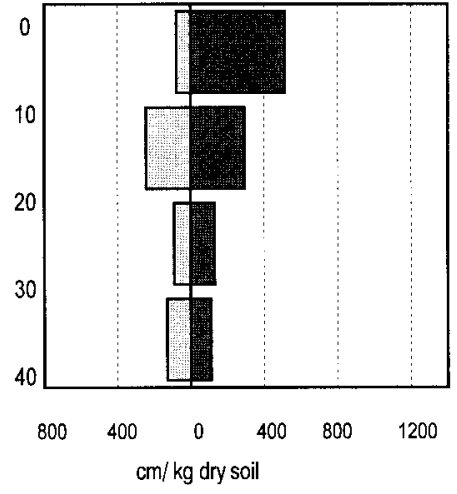

Plant row
Fig. 2. Effect of application method of $250 \mathrm{~kg} \mathrm{ha}^{-1} \mathrm{~N}$ on the cabbage roots ( $\mathrm{cm} \mathrm{kg}^{-1}$ of dry soil) for 30 days after planting (dap) and of $188 \mathrm{~kg} \mathrm{ha}^{-1} \mathrm{~N}$ on the distribution of cabbage roots for 63 days after planting in 1993. Locations of plant row and interrow samples are explained in Figure 1.

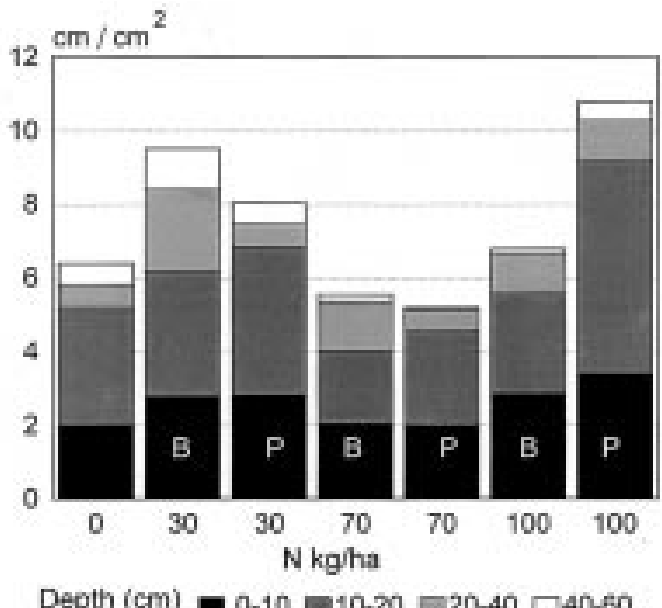

Depth (cm)
$-10=10-20-20-40 \square-40-60$
Fig. 3. Effect of treatments on fibrous carrot root length ( $\mathrm{cm} \mathrm{cm}^{-2}$ of soil surface) for 106 days after sowing in 1993. $\mathrm{B}=$ Broadcast, $\mathrm{P}=$ Placement. (Results have been transformed to $\mathrm{cm}$ of root length per $\mathrm{cm}^{2}$ of soil surface using the estimation based on soil bulk density and sampling depth. At the depths of $0-10 \mathrm{~cm}$ and $10-20 \mathrm{~cm} 1 \mathrm{~kg}$ of soil equals to $72.5 \mathrm{~cm}^{2}$ of soil surface and at the depths of $20-40$ and $40-60 \mathrm{~cm}, 1 \mathrm{~kg}$ of soil equals to $31.4 \mathrm{~cm}^{2}$ of soil surface.) 
Vol. 2 (1999): 157-232.

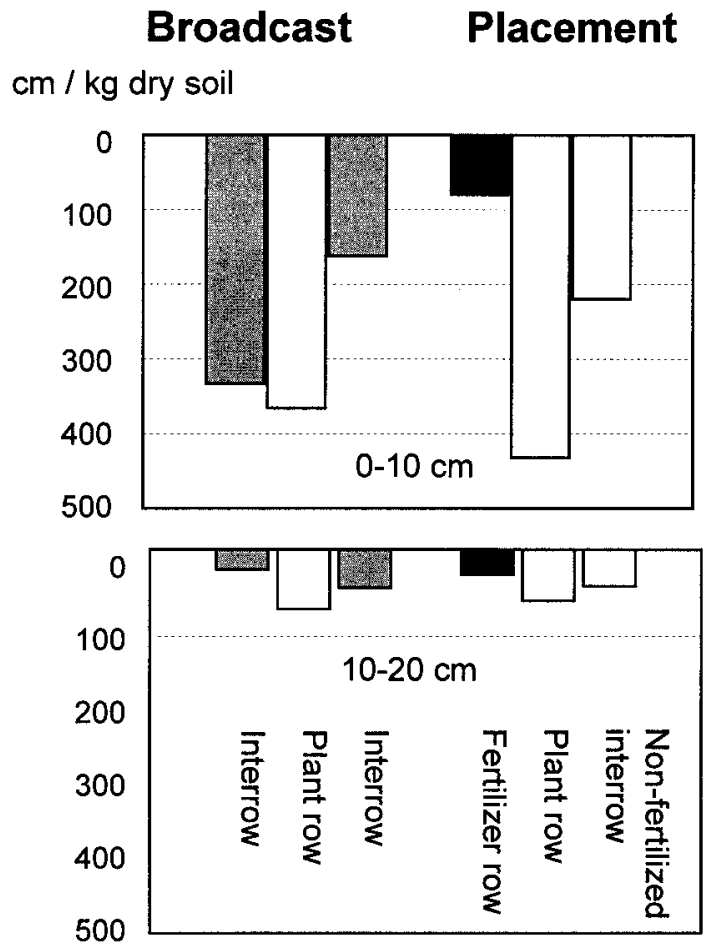

Fig. 4. Effect of application method of $100 \mathrm{~kg} \mathrm{ha}^{-1} \mathrm{~N}$ on the onion root length ( $\mathrm{cm} \mathrm{kg}^{-1}$ of dry soil) for 35 days after planting in 1993. Sampling locations of placement treatment are explained in Figure 1 and interrow locations of broadcast treatment were taken $5 \mathrm{~cm}$ to the side of the onion row.

\section{Onion}

Both 35 and 70 days after planting, most of the roots were at the depth of 0-10 cm (Figs. 4 and 5). One month after planting, at both depths most of the roots were below the onion sets. In addition, there was an interaction between treatments and horizontal location of roots $(P=0.010)$. This interaction was caused by the low amount of roots in the location of the fertilizer band at the depth of $0-10 \mathrm{~cm}$. Two months after planting, roots were spread further to the interrow area. There were still more roots below the onion set than between rows in the $0-10 \mathrm{~cm}$ layer $(\mathrm{P}<0.001)$. But there were no statistically significant differences between root lengths of plant rows and interrows at the depths of $10-20 \mathrm{~cm}$ and $20-30 \mathrm{~cm}$.

\section{Broadcast}

Depth (cm)

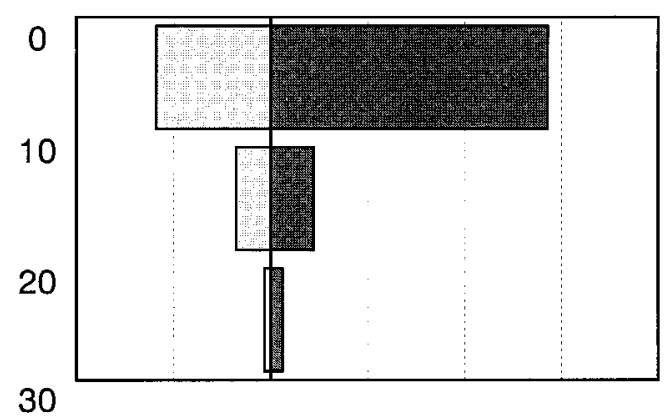

Placement

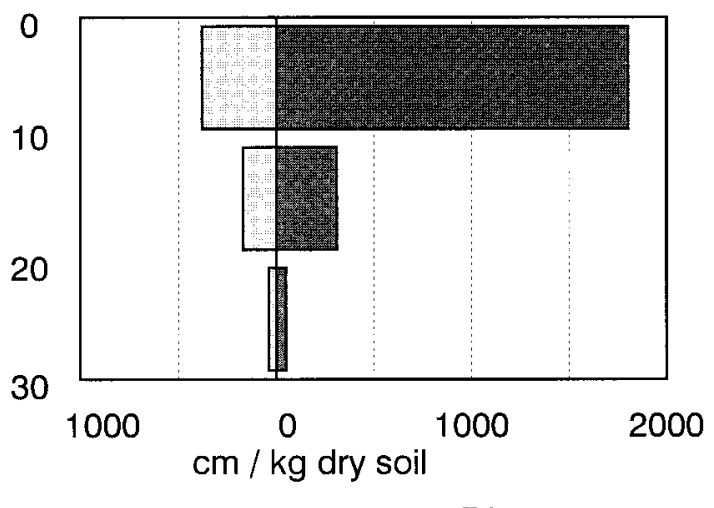

Interrow Plant row

Fig 5. Effect of application method of $70 \mathrm{~kg} \mathrm{ha}^{-1} \mathrm{~N}$ on the onion root length ( $\mathrm{cm} \mathrm{kg}^{-1}$ dry soil) for 70 days after planting in 1993. Sampling locations of the $\mathrm{x}$ axis are explained in Figure 1.

\subsubsection{Dry matter accumulation}

\section{Cabbage}

The above-ground dry weight started to increase rapidly after the first sampling (28-33 dap) each year (Fig. 6). After the first sampling, $\mathrm{N}$ fertilization increased the dry matter accumulation compared to the non-fertilized treatment each year (Tables 13-15 ). In 1993, $\mathrm{N}$ rates higher than $125 \mathrm{~kg} \mathrm{ha}^{-1}$ increased growth only between 


\section{AGRICULTURAL AND FOOD SCIENCE IN FINLAND}

Salo, T. Effects of nitrogen fertilizer on growth of cabbage, carrot and onion

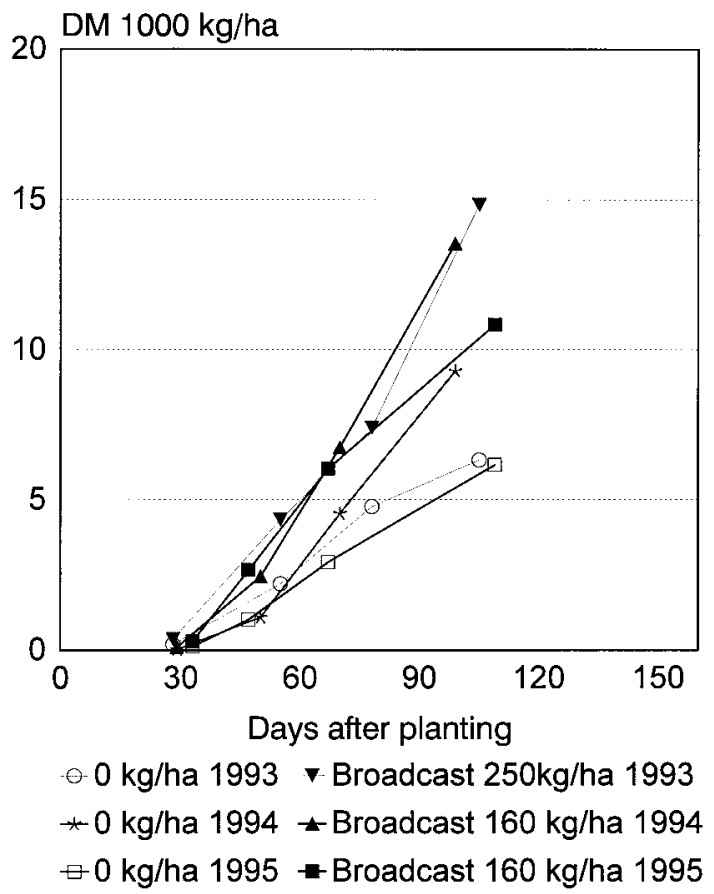

Fig. 6. Dry matter accumulation rate for cabbage in 19931995.

the third sampling (78 dap) and harvest (Table 13), whereas in 1994, $\mathrm{N}$ rates higher than $80 \mathrm{~kg}$ $\mathrm{ha}^{-1}$ did not increase growth (Table 14). At harvest in 1993, the plant dry weights ranged from $6300 \mathrm{~kg} \mathrm{ha}^{-1}$ in the non-fertilized plots to 14800 $\mathrm{kg} \mathrm{ha}^{-1}$ in the $250 \mathrm{~kg} \mathrm{ha}^{-1}$ broadcast plots (Fig. 6). At harvest in 1994, the plant dry weights ranged from $9300 \mathrm{~kg} \mathrm{ha}^{-1}$ in the non-fertilized plots to $13500 \mathrm{~kg} \mathrm{ha}^{-1}$ in the $160 \mathrm{~kg} \mathrm{ha}^{-1}$ broadcast plots. In 1995, dry matter accumulation at harvest without $\mathrm{N}$ fertilizer was $6200 \mathrm{~kg} \mathrm{ha}^{-1}$ and on average $11500 \mathrm{~kg} \mathrm{ha}^{-1}$ with $160 \mathrm{~kg} \mathrm{ha}^{-1} \mathrm{~N}$ fertilizer.

Both in 1993 and 1994, broadcast application resulted in higher dry weight than band placement at the first (28-29 dap) and second (50-55 dap) sampling (Tables 13 and 14). At the third sampling (78 dap) of 1993, $\mathrm{N}$ rates of 188

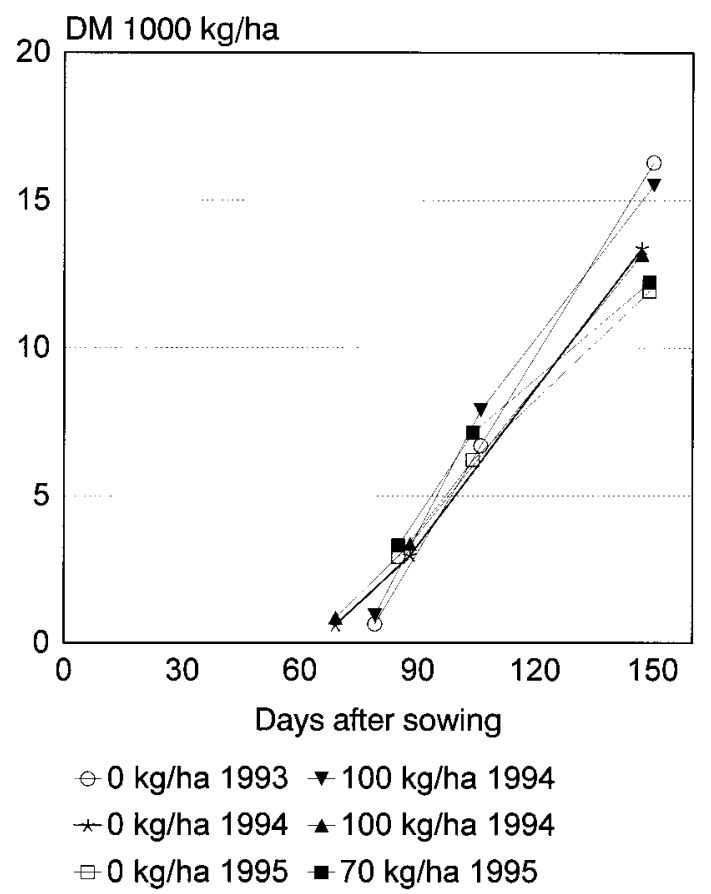

Fig. 7. Dry matter accumulation rate for carrot in 19931995.

and $250 \mathrm{~kg} \mathrm{ha}^{-1}$ gave the highest head dry yields in broadcast application, but in placement application the $\mathrm{N}$ rate of $125 \mathrm{~kg} \mathrm{ha}^{-1}$ produced the highest head dry yield (Table 13). Interaction effect was also observed in the 1993 harvest, when high $\mathrm{N}$ rates increased head dry yields more in broadcast applications than in placement applications (Table 13). In 1994, there were no differences between application methods after the second sampling (Table 14). In 1995, there were no differences between application methods (Table 15).

\section{Carrot}

Dry matter accumulation in shoots and storage roots was similar between the treatments each year (Fig. 7). Dry matter accumulation in the 


\section{AGRICULTURAL AND FOOD SCIENCE IN FINLAND}

Vol. 2 (1999): 157-232.

Table 13. Effect of $\mathrm{N}$ rate and application method on the dry weight of cabbage $\left(\mathrm{kg} \mathrm{ha}^{-1}\right)$ on different days after planting (dap) in 1993.

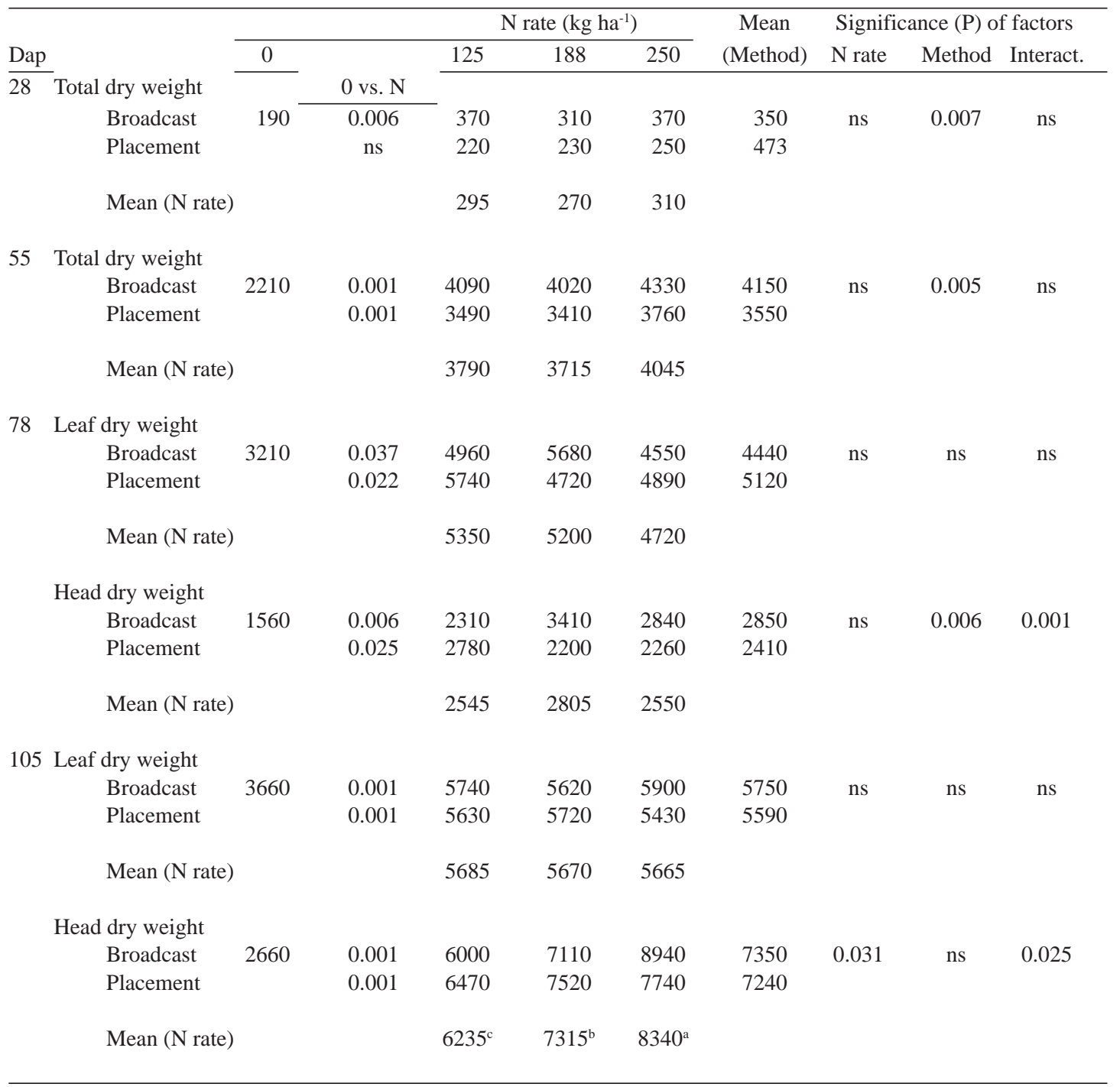

ns = not significant; $\mathrm{P}>0.10$. Means of $\mathrm{N}$ rates $125-250 \mathrm{~kg} \mathrm{ha}^{-1}$ followed by no letter or a common letter do not differ significantly $(\mathrm{P}<0.05)$ according to the contrast test.

Dap = days after planting

0 vs. $\mathrm{N}=$ significance of difference between $0 \mathrm{~kg} \mathrm{ha}^{-1}$ and broadcast or placed $125-250 \mathrm{~kg} \mathrm{ha}^{-1}$.

treatments varied from 12400 to $16600 \mathrm{~kg} \mathrm{ha}^{-1}$ in 1993 , from $12800 \mathrm{~kg} \mathrm{ha}^{-1}$ to $14000 \mathrm{~kg} \mathrm{ha}^{-1}$ in 1994, and from 11900 to $12200 \mathrm{~kg} \mathrm{ha}^{-1}$ in 1995. Non-fertilized treatments produced as high dry matter yields as fertilized treatments. Although plant density in 1995 was only one third of the preceding years, the individual storage roots grew larger than in the preceding years and thus dry matter production increased up to $12000 \mathrm{~kg}$ ha $^{-1}$. 


\section{AGRICULTURAL AND FOOD SCIENCE IN FINLAND}

Salo, T. Effects of nitrogen fertilizer on growth of cabbage, carrot and onion

Table 14. Effect of $\mathrm{N}$ rate and application method on the dry weight of cabbage ( $\left.\mathrm{kg} \mathrm{ha}^{-1}\right)$ on different days after planting (dap) in 1994.

\begin{tabular}{|c|c|c|c|c|c|c|c|c|c|c|}
\hline \multirow{2}{*}{ Dap } & & \multirow[b]{2}{*}{0} & \multirow[b]{3}{*}{0 vs. $\mathrm{N}$} & \multicolumn{3}{|c|}{$\mathrm{N}$ rate $\left(\mathrm{kg} \mathrm{ha}^{-1}\right)$} & \multirow{2}{*}{$\begin{array}{c}\text { Mean } \\
\text { (Method) }\end{array}$} & \multicolumn{3}{|c|}{ Significance $(\mathrm{P})$ of factors } \\
\hline & & & & 80 & 120 & 160 & & $\mathrm{~N}$ rate & Method & Interact. \\
\hline \multirow[t]{4}{*}{29} & Total dry weight & & & & & & & & & \\
\hline & Broadcast & 40 & 0.002 & 90 & 110 & 110 & 100 & ns & 0.001 & ns \\
\hline & Placement & & ns & 40 & 40 & 60 & 50 & & & \\
\hline & Mean ( $\mathrm{N}$ rate) & & & 70 & 70 & 80 & & & & \\
\hline \multirow[t]{4}{*}{50} & Total dry weight & & & & & & & & & \\
\hline & Broadcast & 1100 & 0.001 & 2360 & 2700 & 2460 & 2510 & ns & 0.002 & ns \\
\hline & Placement & & 0.001 & 1880 & 1930 & 1890 & 1900 & & & \\
\hline & Mean ( $\mathrm{N}$ rate) & & & 2120 & 2310 & 2180 & & & & \\
\hline \multirow[t]{8}{*}{70} & Leaf dry weight & & & & & & & & & \\
\hline & Broadcast & 3260 & 0.001 & 4060 & 4190 & 4500 & 4250 & ns & ns & ns \\
\hline & Placement & & 0.052 & 4050 & 3890 & 4050 & 3990 & & & \\
\hline & Mean (N rate) & & & 4050 & 4030 & 4280 & & & & \\
\hline & Head dry weight & & & & & & & & & \\
\hline & Broadcast & 1280 & 0.021 & 1940 & 2120 & 2240 & 2100 & ns & 0.071 & ns \\
\hline & Placement & & $\mathrm{ns}$ & 1750 & 1870 & 1830 & 1800 & & & \\
\hline & Mean (N rate) & & & 1845 & 1990 & 2040 & & & & \\
\hline \multirow[t]{8}{*}{99} & Leaf dry weight & & & & & & & & & \\
\hline & Broadcast & 3980 & 0.001 & 5350 & 5980 & 5800 & 5710 & ns & ns & ns \\
\hline & Placement & & 0.006 & 5340 & 5420 & 5730 & 5500 & & & \\
\hline & Mean (N rate) & & & 5340 & 5700 & 5760 & & & & \\
\hline & Head dry weight & & & & & & & & & \\
\hline & Broadcast & 5310 & 0.001 & 6870 & 7420 & 7740 & 7340 & ns & $\mathrm{ns}$ & $\mathrm{ns}$ \\
\hline & Placement & & 0.006 & 7120 & 7490 & 7090 & 7230 & & & \\
\hline & Mean ( $\mathrm{N}$ rate) & & & 6990 & 7450 & 7420 & & & & \\
\hline
\end{tabular}

$\mathrm{ns}=$ not significant; $\mathrm{P}>0.10$. Means of $\mathrm{N}$ rates $80-160 \mathrm{~kg} \mathrm{ha}^{-1}$ followed by no letter or a common letter do not differ significantly $(\mathrm{P}<0.05)$ according to the contrast test.

Dap $=$ days after planting

0 vs. $\mathrm{N}=$ significance of difference between $0 \mathrm{~kg} \mathrm{ha}^{-1}$ and broadcast or placed $80-160 \mathrm{~kg} \mathrm{ha}^{-1}$.

The dry weight of storage roots increased rapidly from the middle of July until harvest, whereas shoot dry weight increased mainly from July until the middle of August. Method of application and $\mathrm{N}$ rate in 1993, and $\mathrm{N}$ rate in 1994 and 1995, did not affect the dry weights of carrot storage roots or shoots (data not shown). Also the ratio of shoots to total dry weight was not affected by the treatments. 


\section{AGRICULTURAL AND FOOD SCIENCE IN FINLAND}

Vol. 2 (1999): 157-232.

Table 15. Effect of $\mathrm{N}$ rate and application method on the above ground dry weight of cabbage $\left(\mathrm{kg} \mathrm{ha}^{-1}\right)$ on different days after planting (dap) in 1995.

\begin{tabular}{|c|c|c|c|c|c|}
\hline \multicolumn{6}{|c|}{ Days after planting } \\
\hline $\begin{array}{l}\mathrm{N} \text { rate } \\
\mathrm{kg} \mathrm{ha}^{-1}\end{array}$ & $\begin{array}{l}\text { Application } \\
\text { method }\end{array}$ & 33 & 47 & 67 & 109 \\
\hline 0 & & $130^{\mathrm{b}}$ & $1020^{b}$ & $2930^{\mathrm{b}}$ & $6160^{\mathrm{b}}$ \\
\hline 160 & Broadcast & $300^{\mathrm{ab}}$ & $2670^{\mathrm{a}}$ & $6030^{\mathrm{a}}$ & $10830^{\mathrm{a}}$ \\
\hline 160 & Placement & $420^{\mathrm{a}}$ & $2490^{\mathrm{a}}$ & $5180^{\mathrm{a}}$ & $11960^{\mathrm{a}}$ \\
\hline$\overline{\text { Probability }^{*}}$ & & 0.048 & 0.010 & 0.013 & 0.003 \\
\hline
\end{tabular}

${ }^{*}$ Significance of difference between treatments.

Means of the same sampling date followed by a common letter do not differ significantly $(\mathrm{P}<0.05)$.

\section{Onion}

In 1993, dry matter accumulation was low without $\mathrm{N}$ fertilizer, but in 1994 and in 1995, nonfertilized treatments produced similar growth to fertilized treatments (Tables 16 and 17, Fig. 8). The rate of dry matter accumulation was slower in 1994 than in 1993, and the final dry matter yield was also about $2000 \mathrm{~kg} \mathrm{ha}^{-1}$ less in 1994 than in 1993. Bulb dry weight increased in an exponential manner, whereas foliage dry weight increased first rapidly and decreased between the third and fourth sampling in 1993 and 1994 (Tables 16 and 17). In 1995, dry matter accumulation of $4000 \mathrm{~kg} \mathrm{ha}^{-1}$ was low, compared to over $8500 \mathrm{~kg} \mathrm{ha}^{-1}$ and $6500 \mathrm{~kg} \mathrm{ha}^{-1}$ in 1993 and 1994, respectively (Fig. 8). The cause of the weak growth could be in the late planting. Because a long photoperiod tends to promote bulb initiation (Brewster 1990a), leaf growth ceased before there were enough leaves for adequate photosynthesis of the carbohydrates for the bulb.

In 1993, foliage dry weight was increased with $\mathrm{N}$ fertilizer at the third ( 83 dap) and fourth sampling (98 dap). Nitrogen placing resulted in slightly higher foliage dry matter accumulation than broadcasting (Table 16). There were statistically significant differences at the first sampling (34 dap) and the fourth sampling. In 1994, there was only one statistically significant result in foliage dry matter accumulation, at the

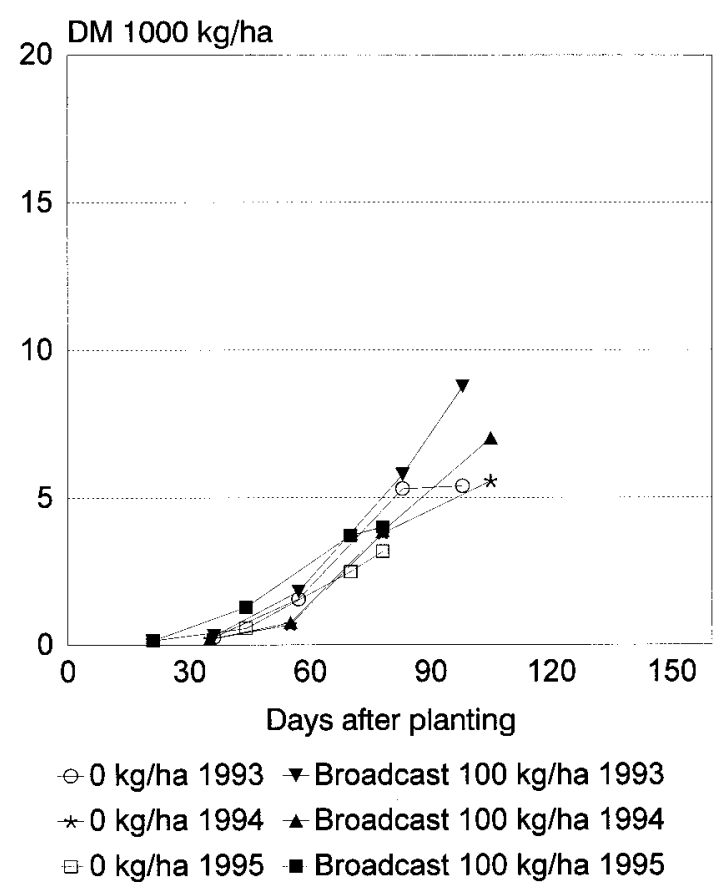

Fig. 8. Dry matter accumulation rate for onion in 1993 1995.

fourth sampling (105 dap) placed $30 \mathrm{~kg} \mathrm{ha}^{-1}$ gave a higher dry weight than broadcast $30 \mathrm{~kg} \mathrm{ha}^{-1}$ (Table 17).

At the first sampling (34 dap) in 1993, placed $70 \mathrm{~kg} \mathrm{ha}^{-1}$ resulted in higher bulb dry weight than 


\section{AGRICULTURAL AND FOOD SCIENCE IN FINLAND}

\section{Salo, T. Effects of nitrogen fertilizer on growth of cabbage, carrot and onion}

Table 16. Effect of $\mathrm{N}$ rate and application method on the onion foliage and onion bulb dry weights $\left(\mathrm{kg} \mathrm{ha}^{-1}\right)$ on different days after planting (dap) in 1993.

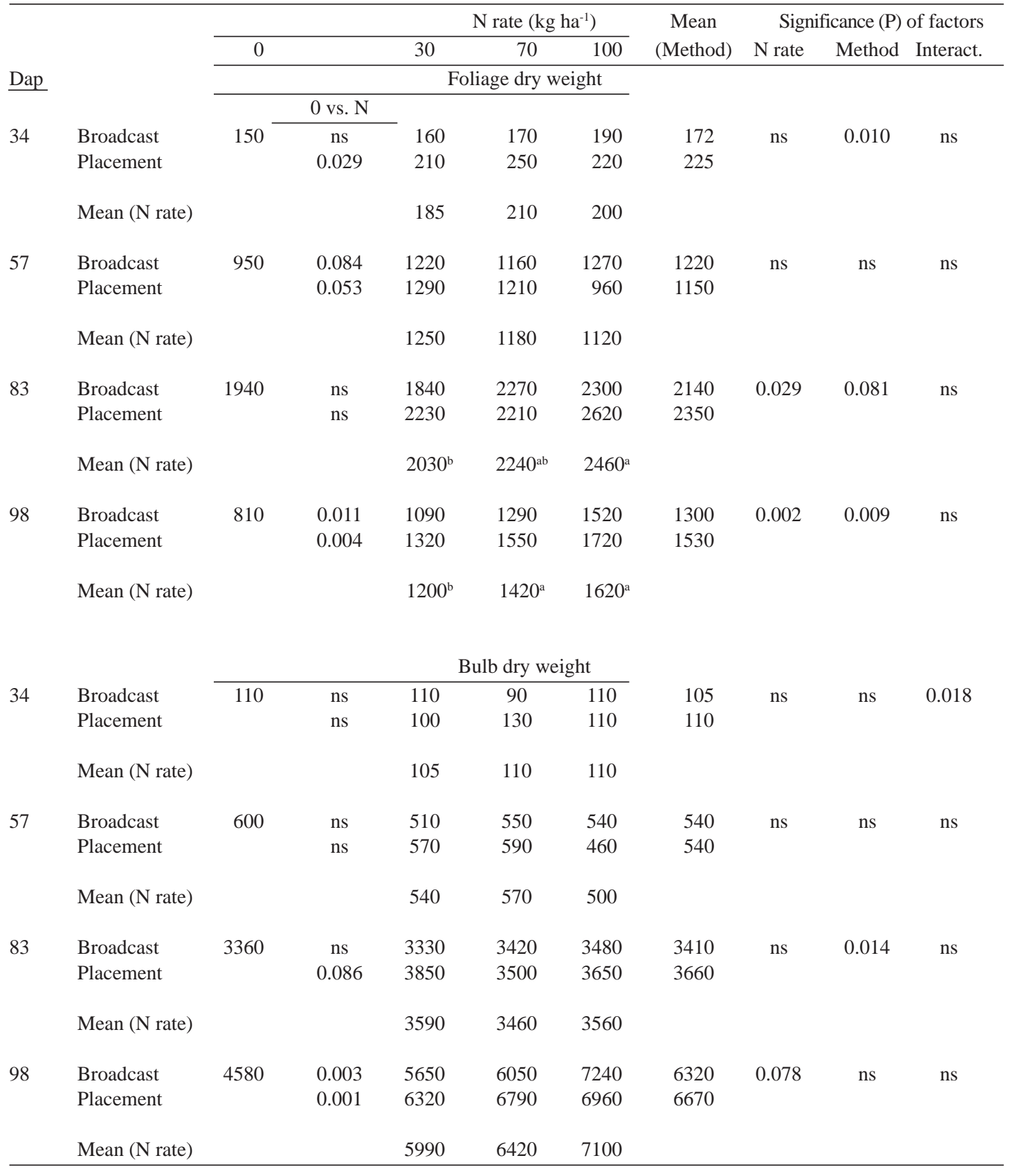

ns = not significant; $\mathrm{P}>0.10$. Means of $\mathrm{N}$ rates $30-100 \mathrm{~kg} \mathrm{ha}^{-1}$ followed by no letter or a common letter do not differ significantly $(\mathrm{P}<0.05)$ according to the contrast test.

Dap = days after planting

0 vs. $\mathrm{N}=$ significance of difference between $0 \mathrm{~kg} \mathrm{ha}^{-1}$ and broadcast or placed $30-100 \mathrm{~kg} \mathrm{ha}^{-1}$. 


\section{AGRICULTURAL AND FOOD SCIENCE IN FINLAND}

Vol. 2 (1999): 157-232.

Table 17. Effect of $\mathrm{N}$ rate and application method on the onion foliage and onion bulb dry weights $\left(\mathrm{kg} \mathrm{ha}^{-1}\right)$ on different days after planting (dap) in 1994.

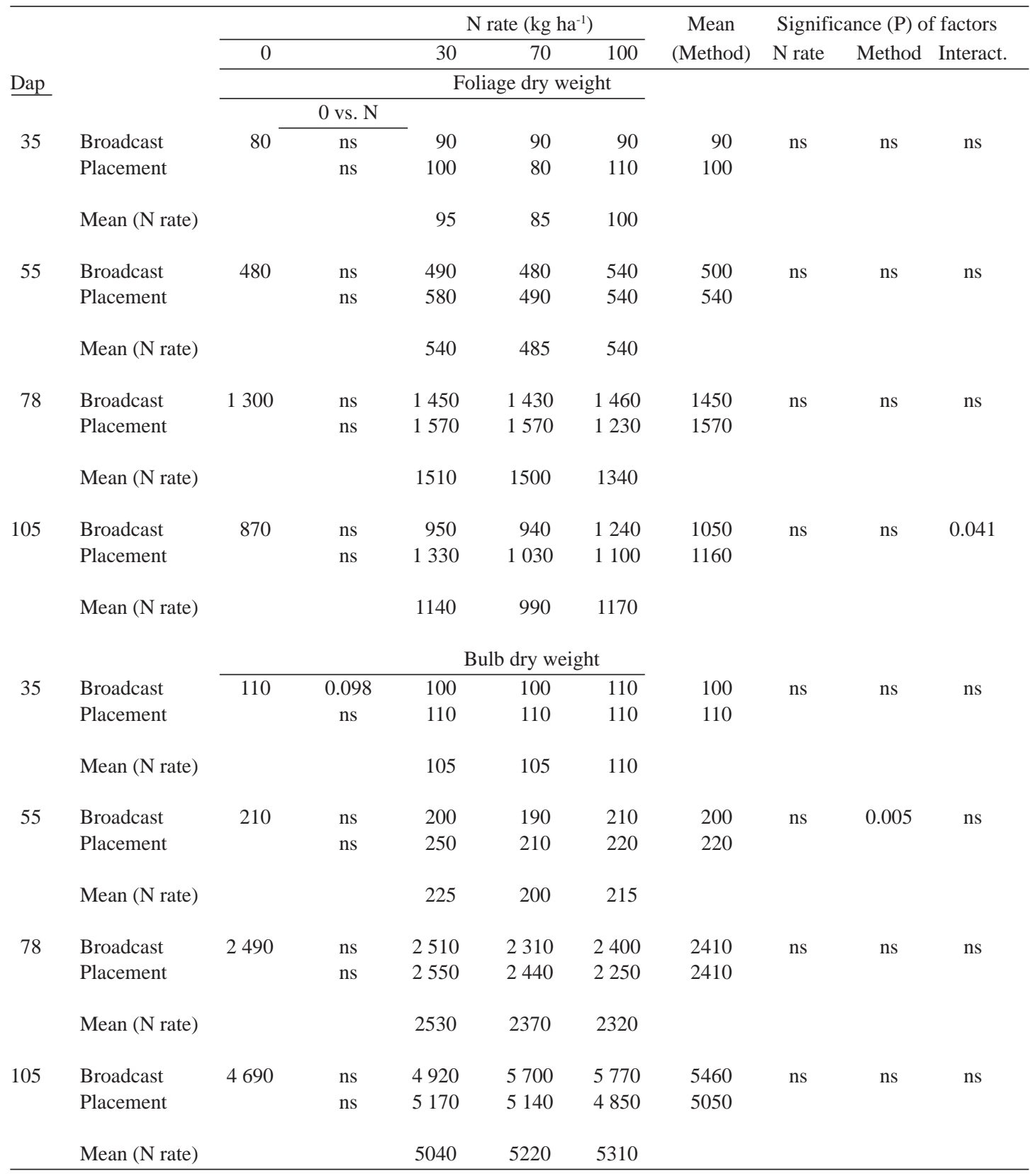

$\mathrm{ns}=$ not significant; $\mathrm{P}>0.10$. Means of $\mathrm{N}$ rates $30-100 \mathrm{~kg} \mathrm{ha}^{-1}$ followed by no letter or a common letter do not differ significantly $(\mathrm{P}<0.05)$ according to the contrast test.

Dap $=$ days after planting

0 vs. $\mathrm{N}=$ significance of difference between $0 \mathrm{~kg} \mathrm{ha}^{-1}$ and broadcast or placed $30-100 \mathrm{~kg} \mathrm{ha}^{-1}$. 


\section{AGRICULTURAL AND FOOD SCIENCE IN FINLAND}

Salo, T. Effects of nitrogen fertilizer on growth of cabbage, carrot and onion

broadcast $70 \mathrm{~kg} \mathrm{ha}^{-1}$. Later, at the third sampling (83 dap), placement resulted in higher bulb dry weight than broadcasting, but at the fourth sampling (98 dap) there was no difference (Table 16). Bulb dry weight was higher when fertilizer was band placed compared to broadcasting at the second sampling (55 dap) in 1994 (Table 17).

\subsubsection{Final yield}

\section{Cabbage}

In 1993, higher $\mathrm{N}$ rates resulted in clearly higher final yields $(P=0.002$, Fig. 9). Non-fertilized plots gave only about $30 \%$ yield compared to the lowest yielding fertilized treatments $(\mathrm{P}=$ $0.001)$. Also broadcasting of $\mathrm{N}$ resulted in higher yields than band placement $(P=0.029)$. The number of heads per hectare varied from 61300 to 63 300, without statistically significant differences.

In 1994, only non-fertilized treatment resulted in a low final yield ( $\mathrm{P}=0.023$, Fig. 9). Even without $\mathrm{N}$, the final yield was $45 \mathrm{t} \mathrm{ha}^{-1}$. $\mathrm{N}$ rates above $80 \mathrm{~kg} \mathrm{ha}^{-1}$ did not increase yield. The number of heads per hectare varied from 34600 to 37900 , and the treatments did not affect head number.
In 1995, non-fertilized treatment resulted in a low final yield of $15 \mathrm{t} \mathrm{ha}^{-1}$ compared to $34 \mathrm{tha}$ ${ }^{1}$ and $41.5 \mathrm{t} \mathrm{ha}^{-1}$ for the $\mathrm{N}$ fertilized treatments ( $\mathrm{P}$ $=0.001)$. The number of heads per hectare varied from 28300 to 38300 , but the treatments had no effect on head number (data not shown).

The sample yields estimated from the four sampled cabbages resulted in yields $6 \%$ higher on average compared to the yields from the $6 \mathrm{~m}^{2}$ area in 1993 (data not shown). In 1994, there were more dead transplants which resulted in $14 \%$ higher yields on average from the samples of four cabbages than from the $6 \mathrm{~m}^{2}$ area. In 1995, high rainfall in June caused waterlogging of the soil and approximately $30 \%$ of the plants were lost. Due to this, the yield calculated from the fourth sample was $36 \%$ to $95 \%$ higher than the yield from the $6 \mathrm{~m}^{2}$ area.

\section{Carrot}

The yield varied between treatments from 76 to $89 \mathrm{t} \mathrm{ha}^{-1}$ in 1993, from 81 to $92 \mathrm{t} \mathrm{ha}^{-1}$ in 1994 and from 34 to $45 \mathrm{t} \mathrm{ha}^{-1}$ in 1995. Marketable yield averaged $61 \mathrm{t} \mathrm{ha}^{-1}$ in 1993, $66 \mathrm{t} \mathrm{ha}^{-1}$ in 1994 and only $9 \mathrm{t} \mathrm{ha}^{-1}$ in 1995. In 1994, $\mathrm{N}$ fertilizer increased the final yield $(\mathrm{P}=0.015$, data not shown), but marketable yield was not affected,
1993

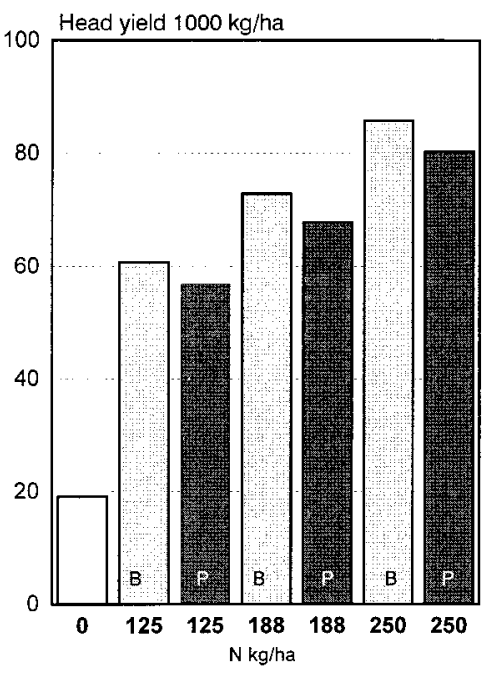

1994

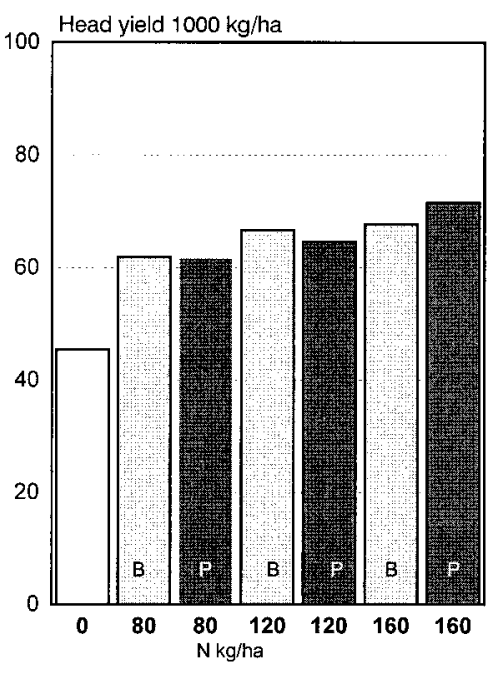

Fig. 9. Effect of $\mathrm{N}$ rate and application method on the head yields of cabbage on fresh weight basis in 1993 and in 1994. B = Broadcast, $\mathrm{P}=$ Placement. 


\section{AGRICULTURAL AND FOOD SCIENCE IN FINLAND}

Vol. 2 (1999): 157-232.

1993

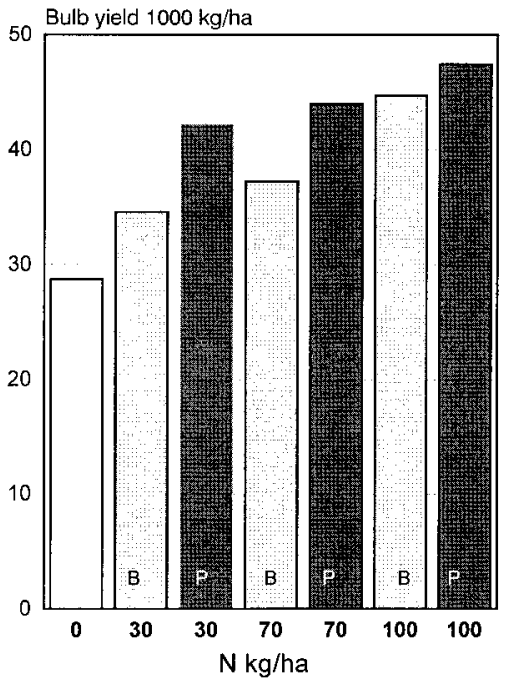

1994

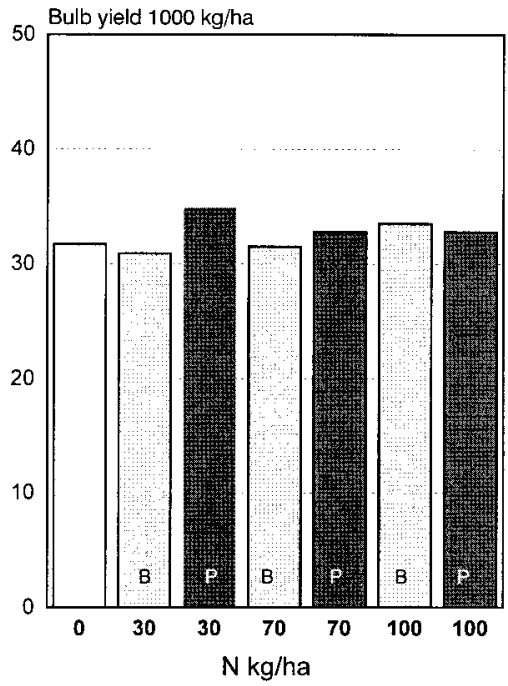

Fig. 10. Effect of $\mathrm{N}$ rate and application method on the bulb fresh yields in 1993 and in 1994. $\mathrm{B}=$ Broadcast, $\mathrm{P}=$ Placement. as the proportion of too large and damaged storage roots increased with the $\mathrm{N}$ rate $(\mathrm{P}=0.023$, data not shown). In 1993, the proportions of branched, split, lift damaged and pest damaged storage roots were $7 \%, 3 \%, 2 \%$ and $1 \%$, respectively. In 1994, the respective values were $9 \%$, $1 \%, 0 \%$ and $8 \%$. In 1995, the proportions of branched and split storage roots were $14 \%$ and $21 \%$. This may have been caused by the soil moisture during the growing season, as initially very moist conditions changed to dry conditions towards harvest. The sampling yield was on average $25 \%$ higher than the final yield in 1993 , $10 \%$ higher in 1994 and $139 \%$ higher in 1995 . In 1995, low marketable yield and the huge difference between the sampling yield and the 12 row metre yield are explained by the much lower plant density than in preceding years. Plant density was on average 730000,785000 and 155000 plants per hectare in years 1993, 1994 and 1995, respectively. In addition to the smaller planned plant density due to the single row in 1995, high rainfall in May eroded the seedbed and seeds were transported by the running water out from the seed row.
Onion

In 1993, final bulb yield was an average 16\% higher when fertilizer was band placed compared to broadcasting ( $\mathrm{P}=0.002$, Fig. 10). In addition, $\mathrm{N}$ rate increased bulb yields $(\mathrm{P}=0.022)$. According to the contrasts, final yield was higher with higher $\mathrm{N}$ rate when fertilizer was broadcast, but not when fertilizer was placed. In placed treatments, final yield was good even with the $30 \mathrm{~kg}$ $\mathrm{ha}^{-1}$ fertilization. In 1994, the $\mathrm{N}$ application method and $\mathrm{N}$ rate did not affect the bulb yield (Fig. 10). Even the non-fertilized treatment produced the same bulb yield as the other treatments. The plant population density i.e. the number of bulbs was not affected by the treatments (Tables 18 and 19). In 1995, final yields were low, $14.7 \mathrm{t} \mathrm{ha}^{-1}$ without $\mathrm{N}$ and $18.1 \mathrm{t} \mathrm{ha}^{-1}$ with $100 \mathrm{~kg} \mathrm{ha}^{-1}$ of $\mathrm{N}(\mathrm{P}=0.054)$.

Calculated from the fourth sampling, the sample yield of bulbs was from 8 to $24 \%$ higher than the final yield calculated from 12 row metres in 1993, but only 1-10\% higher in 1994 (data not shown). These differences were low as the bulbs from 12 row metres were dried for two 


\section{AGRICULTURAL AND FOOD SCIENCE IN FINLAND}

Salo, T. Effects of nitrogen fertilizer on growth of cabbage, carrot and onion

Table 18. Effect of $\mathrm{N}$ rate and application method on the size distribution of harvested onion bulbs in 1993. The number of bulbs is presented as 1000 bulbs ha ${ }^{-1}$.

\begin{tabular}{|c|c|c|c|c|c|c|}
\hline \multirow[b]{2}{*}{$\begin{array}{l}\mathrm{N} \text { rate } \\
\mathrm{kg} \mathrm{ha}^{-1}\end{array}$} & \multirow[b]{2}{*}{$\begin{array}{l}\text { Application } \\
\text { method }\end{array}$} & \multirow[b]{2}{*}{$<4$} & \multicolumn{2}{|c|}{ Diameter in $\mathrm{cm}$} & \multirow[b]{2}{*}{$>7.1$} & \multirow[b]{2}{*}{ Sum } \\
\hline & & & $4.0-5.5$ & $5.6-7.0$ & & \\
\hline 0 & & 29 & 173 & 134 & 1 & 337 \\
\hline 30 & Broadcast & 16 & 119 & 205 & 2 & 342 \\
\hline 30 & Placement & 7 & 83 & 240 & 11 & 341 \\
\hline 70 & Broadcast & 10 & 86 & 219 & 6 & 321 \\
\hline 70 & Placement & 7 & 62 & 253 & 16 & 338 \\
\hline 100 & Broadcast & 5 & 60 & 258 & 18 & 341 \\
\hline 100 & Placement & 5 & 49 & 261 & 29 & 344 \\
\hline \multicolumn{7}{|l|}{ Probability* } \\
\hline $\mathrm{N}$ rate & & 0.018 & 0.012 & 0.065 & 0.021 & $\mathrm{~ns}$ \\
\hline Method & & 0.052 & 0.004 & 0.022 & 0.019 & ns \\
\hline Interaction & & 0.073 & ns & ns & ns & ns \\
\hline
\end{tabular}

$\mathrm{ns}=$ not significant, $(\mathrm{P}>0.10)$.

*Significance of difference between $\mathrm{N}$ rates or application methods in each diameter class and total sum.

Table 19. Effect of $\mathrm{N}$ rate and application method on the size distribution of harvested onion bulbs in 1994. The number of bulbs is presented as 1000 bulbs ha $^{-1}$.

\begin{tabular}{|c|c|c|c|c|c|c|}
\hline \multirow[b]{2}{*}{$\begin{array}{l}\mathrm{N} \text { rate } \\
\mathrm{kg} \mathrm{ha}^{-1}\end{array}$} & \multirow[b]{2}{*}{$\begin{array}{l}\text { Application } \\
\text { method }\end{array}$} & \multirow[b]{2}{*}{$<4$} & \multicolumn{2}{|c|}{ Diameter in $\mathrm{cm}$} & \multirow[b]{2}{*}{$>7.1$} & \multirow[b]{2}{*}{ Sum } \\
\hline & & & $4.0-5.5$ & $5.6-7.0$ & & \\
\hline 0 & & 12 & 205 & 126 & 1 & 344 \\
\hline 30 & Broadcast & 10 & 210 & 124 & 0 & 344 \\
\hline 30 & Placement & 8 & 179 & 172 & 0 & 358 \\
\hline 70 & Broadcast & 12 & 196 & 134 & 1 & 343 \\
\hline 70 & Placement & 7 & 179 & 146 & 0 & 332 \\
\hline 100 & Broadcast & 5 & 187 & 165 & 1 & 358 \\
\hline 100 & Placement & 9 & 187 & 144 & 1 & 341 \\
\hline \multicolumn{7}{|l|}{ Probability $^{*}$} \\
\hline $\mathrm{N}$ rate & & ns & ns & ns & ns & ns \\
\hline Method & & ns & ns & ns & $\mathrm{ns}$ & $\mathrm{ns}$ \\
\hline Interaction & & $\mathrm{ns}$ & $\mathrm{ns}$ & 0.022 & $\mathrm{~ns}$ & $\mathrm{~ns}$ \\
\hline
\end{tabular}

$\mathrm{ns}=$ not significant, $(\mathrm{P}>0.10)$.

*Significance of difference between $\mathrm{N}$ rates or application methods in each diameter class and total sum.

months in the greenhouse, which should result in lower yields in any case. In 1995, the final yield of bulbs calculated from 12 row metres was $7-11 \%$ higher than the yield calculated from the sample. The probable cause was that while the shoots had fallen the onions were kept for two weeks in the field, and there was translocation of dry matter from shoots to bulbs.

In 1993, bulbs were larger with higher $\mathrm{N}$ rates and with band placement (Table 18). Without $\mathrm{N}$ fertilizer, the proportion of small $(<4 \mathrm{~cm})$ bulbs was high, almost $10 \%$ of all bulbs. In 1994, the 


\section{AGRICULTURAL AND FOOD SCIENCE IN FINLAND}

Vol. 2 (1999): 157-232.

proportion of small $(<4 \mathrm{~cm})$ and large $(>7.1$ cm) bulbs was low (Table 19). In 1994, placement increased bulb size when the $\mathrm{N}$ rate was low, but at a $\mathrm{N}$ rate of $100 \mathrm{~kg} \mathrm{ha}^{-1}$ broadcasting resulted in larger bulbs than placement. In 1995, bulb distribution was not changed by $\mathrm{N}$ fertilization (data not shown).

\subsubsection{Dry matter content}

\section{Cabbage}

Leaf dry matter content varied from $8.1 \%$ to $16.3 \%$ during the growing seasons and there was no trend of dry matter content increasing towards harvest. Head dry matter content increased in the latter part of the growing season from an average $7.7 \%$ to $9.9 \%$ in 1993 and 1994 .

The dry matter contents of both heads and leaves at harvest in 1993 were slightly lower when the $\mathrm{N}$ rate was high (data not shown). Leaf dry matter content was $13.0 \%$ in the $125 \mathrm{~kg} \mathrm{ha}^{-1}$ fertilized treatments and $10.8 \%$ in the $250 \mathrm{~kg} \mathrm{ha}^{-1}$ fertilized treatments, and head dry matter content was $10.7 \%$ and $9.4 \%$ in the respective treatments. Otherwise there were no statistically significant differences between dry matter contents in 1993 and 1994 (data not shown). At the first sampling (33 dap) of 1995, dry matter content was higher in the placed treatment than in the others. At the second sampling (47 dap) in 1995 the dry matter content of non-fertilized cabbages was higher than the dry matter content of $\mathrm{N}$ fertilized (data not shown).

\section{Carrot}

The dry matter content of the storage roots varied from $10.0 \%$ to $14.1 \%$ during the three growing seasons. At harvest the dry matter content of the storage roots was on average $11.3 \%$. The dry matter content of the foliage increased towards harvest to $19.2 \%$ in 1993 and 1995, but was only $14.2 \%$ in 1994. Treatments did not affect dry matter contents (data not shown).

\section{Onion}

Bulb dry matter content increased from $8.0 \%$ at the first sampling to $14.0 \%$ at harvest in 1993 , and to $19.0 \%$ in 1995 . In 1994, bulb dry matter content at the first sampling (35 dap) was $10.0 \%$ and increased to an average $15.8 \%$ at harvest. Dry matter content of foliage decreased from $11.0 \%$ at the first sampling (34 dap) to $7.0 \%$ at harvest in 1993. In 1994, foliage dry matter content varied from $8.3 \%$ to $9.5 \%$ in the different samplings, without any clear trend caused by time. Nitrogen rate decreased foliage dry matter content in the latter part of the growing period, but by only 0.5 percentage points in 1993 (data not shown). Placement compared to broadcasting led to 0.8 percentage points higher dry matter content in bulb and 0.4 percentage points higher dry matter content in foliage at the first sampling (34 dap) in 1993. Also in 1994, placement resulted in slightly higher dry matter contents at the first (35 dap) and second (55 dap) samplings (data not shown). However, these changes in dry matter contents were less than 0.5 percentage points.

In 1995 , bulb dry matter content increased from $8.6 \%$ at the first sampling (21 dap) to $19.0 \%$ at harvest. Dry matter content of foliage increased from $8.2 \%$ to $10.8 \%$ to the third sampling (70 dap) and then decreased to $9.8 \%$ at harvest. $\mathrm{N}$ fertilization did not cause any statistically significant differences in 1995 (data not shown).

\subsection{Nitrogen uptake by plants}

\subsubsection{Plant nitrogen concentration}

\section{Cabbage}

Leaf $\mathrm{N}$ concentrations decreased clearly during the growing periods 1993 and 1994 (Tables 20 and 21). In 1995, leaf $\mathrm{N}$ concentration decreased from $50-56 \mathrm{~g} \mathrm{~kg}^{-1} \mathrm{DM}$ to $27 \mathrm{~g} \mathrm{~kg}^{-1} \mathrm{DM}$ in the $\mathrm{N}$ 


\section{AGRICULTURAL AND FOOD SCIENCE IN FINLAND}

Salo, T. Effects of nitrogen fertilizer on growth of cabbage, carrot and onion

Table 20. Effect of $\mathrm{N}$ rate and application method on the total $\mathrm{N}$ concentration in cabbage tops, leaves or heads $\left(\mathrm{g} \mathrm{kg}^{-1} \mathrm{DM}\right)$ on different days after planting (dap) in 1993.

\begin{tabular}{|c|c|c|c|c|c|c|c|c|c|c|}
\hline \multirow[b]{2}{*}{ Dap } & \multirow[b]{2}{*}{ Sample } & \multirow[b]{2}{*}{0} & \multirow[b]{3}{*}{0 vs. $\mathrm{N}$} & \multicolumn{3}{|c|}{$\mathrm{N}$ rate $\left(\mathrm{kg} \mathrm{ha}^{-1}\right)$} & \multirow{2}{*}{$\begin{array}{c}\text { Mean } \\
\text { (Method) }\end{array}$} & \multicolumn{3}{|c|}{ Significance $(\mathrm{P})$ of factors } \\
\hline & & & & 125 & 188 & 250 & & $\mathrm{~N}$ rate & Method & Interact. \\
\hline \multirow[t]{4}{*}{28} & Tops & & & & & & & & & \\
\hline & Broadcast & 47.5 & 0.001 & 55.1 & 55.4 & 56.1 & 55.5 & ns & ns & ns \\
\hline & Placement & & 0.001 & 56.2 & 56.8 & 55.2 & 56.0 & & & \\
\hline & Mean ( $\mathrm{N}$ rate) & & & 55.6 & 56.1 & 55.6 & & & & \\
\hline \multirow[t]{4}{*}{55} & Tops & & & & & & & & & \\
\hline & Broadcast & 21.1 & 0.001 & 33.1 & 36.8 & 46.0 & 36.5 & 0.012 & 0.001 & ns \\
\hline & Placement & & 0.001 & 39.3 & 41.3 & 44.6 & 41.7 & & & \\
\hline & Mean ( $\mathrm{N}$ rate) & & & $36.2^{\mathrm{b}}$ & $39.1^{\mathrm{ab}}$ & $42.1^{\mathrm{a}}$ & & & & \\
\hline \multirow[t]{8}{*}{78} & Leaves & & & & & & & & & \\
\hline & Broadcast & 13.0 & 0.001 & 17.6 & 26.8 & 28.0 & 24.1 & 0.001 & ns & 0.040 \\
\hline & Placement & & 0.001 & 19.7 & 24.7 & 30.3 & 24.9 & & & \\
\hline & Mean (N rate) & & & $18.7^{\mathrm{c}}$ & $25.7^{\mathrm{b}}$ & $29.1^{\mathrm{a}}$ & & & & \\
\hline & Heads & & & & & & & & & \\
\hline & Broadcast & 21.6 & 0.001 & 24.9 & 30.5 & 31.6 & 29.0 & 0.004 & $\mathrm{~ns}$ & $\mathrm{~ns}$ \\
\hline & Placement & & 0.001 & 27.4 & 31.0 & 32.1 & 30.2 & & & \\
\hline & Mean (N rate) & & & $26.1^{\mathrm{b}}$ & $30.7^{\mathrm{a}}$ & $31.8^{\mathrm{a}}$ & & & & \\
\hline \multirow[t]{8}{*}{105} & Leaves & & & & & & & & & \\
\hline & Broadcast & 13.6 & 0.001 & 15.0 & 19.6 & 23.5 & 19.4 & 0.001 & ns & ns \\
\hline & Placement & & 0.001 & 16.7 & 19.1 & 24.0 & 19.9 & & & \\
\hline & Mean ( $\mathrm{N}$ rate) & & & $15.9^{\mathrm{c}}$ & $19.3^{\mathrm{b}}$ & $23.7^{\mathrm{a}}$ & & & & \\
\hline & Heads & & & & & & & & & \\
\hline & Broadcast & 15.4 & 0.018 & 15.5 & 18.0 & 19.4 & 17.6 & 0.001 & ns & ns \\
\hline & Placement & & 0.001 & 15.3 & 17.7 & 20.3 & 17.7 & & & \\
\hline & Mean (N rate) & & & $15.4^{\mathrm{c}}$ & $17.8^{\mathrm{b}}$ & $19.8^{\mathrm{a}}$ & & & & \\
\hline
\end{tabular}

$\mathrm{ns}=$ not significant; $\mathrm{P}>0.10$. Means of $\mathrm{N}$ rates $125-250 \mathrm{~kg} \mathrm{ha}^{-1}$ followed by no letter or a common letter do not differ significantly $(\mathrm{P}<0.05)$ according to the contrast test.

Dap = days after planting

0 vs. $\mathrm{N}=$ significance of difference between $0 \mathrm{~kg} \mathrm{ha}^{-1}$ and broadcast or placed $125-250 \mathrm{~kg} \mathrm{ha}^{-1}$.

fertilized treatments. Head $\mathrm{N}$ concentrations decreased every year as in 1995, when the $\mathrm{N}$ concentration of heads decreased from over $30 \mathrm{~g} \mathrm{~kg}^{-1}$ DM (67 dap) to nearly $20 \mathrm{~g} \mathrm{~kg}^{-1} \mathrm{DM}$ at harvest. Both leaf and head $\mathrm{N}$ concentration were lower without $\mathrm{N}$ fertilizer than with $\mathrm{N}$ fertilizer in all years.
At the first sampling (28 dap) in 1993, $\mathrm{N}$ concentrations were still equal in all $\mathrm{N}$ fertilized treatments (Table 20). At the second sampling (55 dap) the highest $\mathrm{N}$ rate resulted in slightly higher $\mathrm{N}$ concentrations than lower $\mathrm{N}$ rates. In addition, placement application led to higher $\mathrm{N}$ concentrations than broadcasting of N. At the third sam- 


\section{AGRICULTURAL AND FOOD SCIENCE IN FINLAND}

Vol. 2 (1999): 157-232.

Table 21. Effect of $\mathrm{N}$ rate and application method on the total $\mathrm{N}$ concentration in cabbage tops, leaves or heads $\left(\mathrm{g} \mathrm{kg}^{-1} \mathrm{DM}\right)$ on different days after planting (dap) in 1994.

\begin{tabular}{|c|c|c|c|c|c|c|c|c|c|c|}
\hline \multirow[b]{2}{*}{ Dap } & \multirow[b]{2}{*}{ Sample } & \multirow[b]{2}{*}{0} & \multirow[b]{3}{*}{0 vs. $\mathrm{N}$} & \multicolumn{3}{|c|}{$\mathrm{N}$ rate $\left(\mathrm{kg} \mathrm{ha}^{-1}\right)$} & \multirow{2}{*}{$\begin{array}{c}\text { Mean } \\
\text { (Method) }\end{array}$} & \multicolumn{3}{|c|}{ Significance $(\mathrm{P})$ of factors } \\
\hline & & & & 80 & 120 & 160 & & $\mathrm{~N}$ rate & Method & Interact. \\
\hline \multirow[t]{4}{*}{29} & Tops & & & & & & & & & \\
\hline & Broadcast & 59.6 & 0.001 & 63.3 & 63.8 & 64.8 & 63.9 & ns & 0.007 & ns \\
\hline & Placement & & 0.083 & 60.7 & 61.6 & 62.8 & 61.7 & & & \\
\hline & Mean ( $\mathrm{N}$ rate) & & & 62.0 & 62.7 & 63.8 & & & & \\
\hline \multirow[t]{4}{*}{50} & Tops & & & & & & & & & \\
\hline & Broadcast & 33.1 & 0.001 & 42.4 & 46.3 & 46.1 & 44.9 & 0.049 & 0.001 & ns \\
\hline & Placement & & 0.001 & 50.0 & 52.3 & 51.5 & 51.3 & & & \\
\hline & Mean ( $\mathrm{N}$ rate) & & & $46.2^{\mathrm{b}}$ & $49.3^{\mathrm{a}}$ & $48.8^{\mathrm{a}}$ & & & & \\
\hline \multirow[t]{8}{*}{70} & Leaves & & & & & & & & & \\
\hline & Broadcast & 25.9 & 0.001 & 31.8 & 36.6 & 38.9 & 35.8 & 0.006 & 0.006 & ns \\
\hline & Placement & & 0.001 & 37.6 & 39.8 & 39.3 & 38.9 & & & \\
\hline & Mean ( $\mathrm{N}$ rate) & & & $34.7^{\mathrm{b}}$ & $38.2^{\mathrm{a}}$ & $39.1^{\mathrm{a}}$ & & & & \\
\hline & Heads & & & & & & & & & \\
\hline & Broadcast & 29.3 & 0.002 & 30.9 & 33.3 & 35.1 & 33.1 & ns & 0.021 & ns \\
\hline & Placement & & 0.004 & 36.5 & 35.7 & 35.4 & 35.9 & & & \\
\hline & Mean ( $\mathrm{N}$ rate) & & & 33.7 & 34.5 & 35.2 & & & & \\
\hline \multirow[t]{8}{*}{99} & Leaves & & & & & & & & & \\
\hline & Broadcast & 18.7 & 0.001 & 23.9 & 27.5 & 27.3 & 26.2 & $\mathrm{~ns}$ & 0.006 & $\mathrm{~ns}$ \\
\hline & Placement & & 0.001 & 27.1 & 29.4 & 28.0 & 28.2 & & & \\
\hline & Mean (N rate) & & & 25.5 & 28.4 & 27.7 & & & & \\
\hline & Heads & & & & & & & & & \\
\hline & Broadcast & 16.0 & 0.001 & 19.7 & 22.9 & 23.2 & 21.9 & 0.015 & $\mathrm{~ns}$ & ns \\
\hline & Placement & & 0.001 & 21.6 & 24.1 & 22.7 & 22.8 & & & \\
\hline & Mean ( $\mathrm{N}$ rate) & & & $20.7^{\mathrm{b}}$ & $23.5^{\mathrm{a}}$ & $22.9^{\mathrm{a}}$ & & & & \\
\hline
\end{tabular}

ns = not significant; $\mathrm{P}>0.10$. Means of $\mathrm{N}$ rates $80-160 \mathrm{~kg} \mathrm{ha}^{-1}$ followed by no letter or a common letter do not differ significantly $(\mathrm{P}<0.05)$ according to the contrast test.

Dap = days after planting

0 vs. $\mathrm{N}=$ significance of difference between $0 \mathrm{~kg} \mathrm{ha}^{-1}$ and broadcast or placed $80-160 \mathrm{~kg} \mathrm{ha}^{-1}$.

pling (78 dap) high $\mathrm{N}$ rates resulted in high $\mathrm{N}$ concentrations both in the leaves and in the heads. At harvest the differences in $\mathrm{N}$ concentrations had increased further, and in the leaves of fertilized treatments varied from 15.0 to $24.0 \mathrm{~g} \mathrm{~kg}^{-1} \mathrm{DM}$ and from 15.3 to $20.3 \mathrm{~g} \mathrm{~kg}^{-1} \mathrm{DM}$ in the heads.
In 1994, plant $\mathrm{N}$ concentrations were higher in broadcast treatments than in placement treatments one month after planting (Table 21). At the second sampling (50 dap), the differences in plant $\mathrm{N}$ concentration due to method were reversed. Placement application produced clearly 


\section{AGRICULTURAL AND FOOD SCIENCE IN FINLAND}

Salo, T. Effects of nitrogen fertilizer on growth of cabbage, carrot and onion

Table 22. Effect of $\mathrm{N}$ rate and application method on the total $\mathrm{N}$ concentration $\left(\mathrm{g} \mathrm{kg}^{-1} \mathrm{DM}\right)$ of carrot roots and shoots on different days after sowing (das) in 1993.

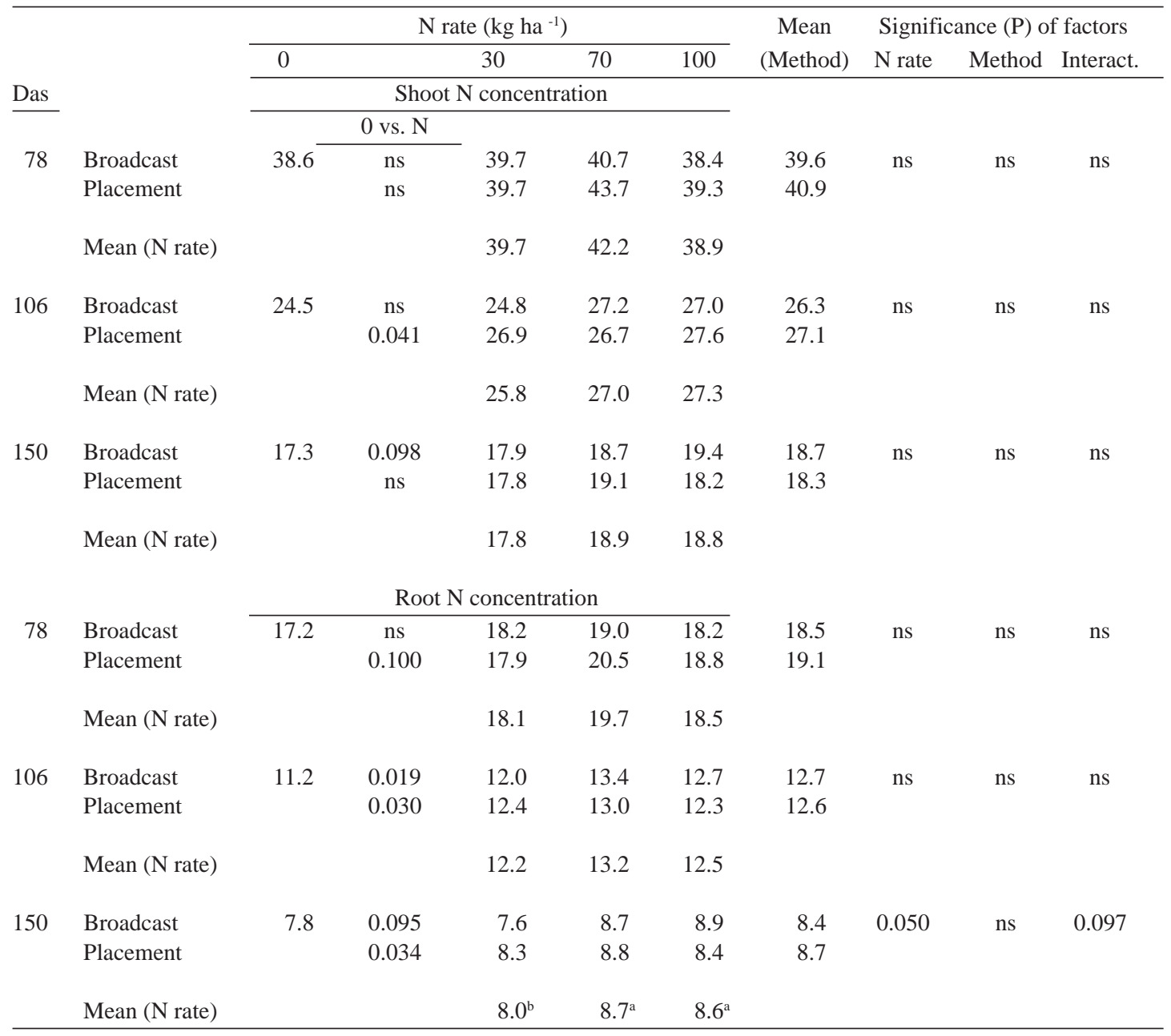

$\mathrm{ns}=$ not significant; $\mathrm{P}>0.10$. Means of $\mathrm{N}$ rates $30-100 \mathrm{~kg} \mathrm{ha}^{-1}$ followed by no letter or a common letter do not differ significantly $(\mathrm{P}<0.05)$ according to the contrast test.

Das = days after sowing

0 vs. $\mathrm{N}=$ significance of difference between $0 \mathrm{~kg} \mathrm{ha}^{-1}$ and broadcast or placed $30-100 \mathrm{~kg} \mathrm{ha}^{-1}$.

higher $\mathrm{N}$ concentrations than broadcast application. At this sampling, high $\mathrm{N}$ rate also resulted in slightly higher $\mathrm{N}$ concentrations. In the separate head and leaf $\mathrm{N}$ concentrations of the third sampling (70 dap) and harvest, placement again produced higher $\mathrm{N}$ concentrations than broadcasting, excluding head $\mathrm{N}$ concentration at harvest. High $\mathrm{N}$ rate resulted in higher leaf $\mathrm{N}$ concentrations at the third sampling (70 dap) and head $\mathrm{N}$ concentrations at harvest. At the first sampling (33 dap) in 1995, the leaf $\mathrm{N}$ concentration in the placed treatment was $6.0 \mathrm{~g} \mathrm{~kg}^{-1} \mathrm{DM}$ higher than the $\mathrm{N}$ concentration in the broadcast treatment $(\mathrm{P}<0.001)$.

\section{Carrot}

Shoot N concentration decreased from over 40 


\section{AGRICULTURAL AND FOOD SCIENCE IN FINLAND}

Vol. 2 (1999): 157-232.

$\mathrm{g} \mathrm{kg}^{-1} \mathrm{DM}$ at the first sampling (69-78 das) to about $20 \mathrm{~g} \mathrm{~kg}^{-1} \mathrm{DM}$ at harvest (Tables 22 and 23). Nitrogen concentration of the carrot storage roots decreased from about $20 \mathrm{~g} \mathrm{~kg}^{-1} \mathrm{DM}$ at the first sampling to nearly $10 \mathrm{~g} \mathrm{~kg}^{-1} \mathrm{DM}$ at harvest.

Nitrogen fertilizer led to higher storage root and shoot $\mathrm{N}$ concentrations at the second sampling (106 das) in 1993, compared to $\mathrm{N}$ concentrations in non-fertilized plants (Table 22). Furthermore at harvest $\mathrm{N}$ rates of $70 \mathrm{~kg} \mathrm{ha}^{-1}$ and 100 $\mathrm{kg} \mathrm{ha}^{-1}$ led to higher storage root $\mathrm{N}$ concentrations than the $\mathrm{N}$ rate of $30 \mathrm{~kg} \mathrm{ha}^{-1}$ when $\mathrm{N}$ was broadcast (Table 22). In 1994, $\mathrm{N}$ concentrations in shoots and storage roots increased with $\mathrm{N}$ fertilizer at the second sampling ( 88 das) and at harvest (Table 23). In 1995, storage root $\mathrm{N}$ concentration increased by $1.2 \mathrm{~g} \mathrm{~kg}^{-1} \mathrm{DM}$ at the first sampling ( 84 das, $\mathrm{P}=0.012$ ) with $\mathrm{N}$ fertilizer.

\section{Onion}

Foliage $\mathrm{N}$ concentration decreased clearly during the growing period (Tables 24 and 25). For example in 1995 , foliage $\mathrm{N}$ concentration decreased from $44 \mathrm{~g} \mathrm{~kg}^{-1} \mathrm{DM}$ to $23 \mathrm{~g} \mathrm{~kg}^{-1} \mathrm{DM}$ in the $\mathrm{N}$ fertilized treatment. Bulb $\mathrm{N}$ concentration decreased until the third sampling (70-83 dap) but increased towards harvest in all three years. Both foliage and bulb $\mathrm{N}$ concentration were lower without $\mathrm{N}$ fertilizer than with $\mathrm{N}$ fertilizer in all years.

The $\mathrm{N}$ rate of $30 \mathrm{~kg} \mathrm{ha}^{-1}$ resulted in lower foliage $\mathrm{N}$ concentrations at the second (34 dap) and third samplings (57 dap) in 1993 than the $\mathrm{N}$ rates of $70 \mathrm{~kg} \mathrm{ha}^{-1}$ and $100 \mathrm{~kg} \mathrm{ha}^{-1}$ (Table 24). When $\mathrm{N}$ fertilizer was placed, foliage $\mathrm{N}$ concentration was higher in all samplings in 1993 compared to broadcast N (Table 24). At harvest, placed high rates of $\mathrm{N}$ led to higher foliage $\mathrm{N}$ concentrations than broadcast high rates of $\mathrm{N}$. In 1994, the $\mathrm{N}$ rate of $30 \mathrm{~kg} \mathrm{ha}^{-1}$ resulted in lower foliage $\mathrm{N}$ concentrations than $\mathrm{N}$ rates of 70 $\mathrm{kg} \mathrm{ha}^{-1}$ and $100 \mathrm{~kg} \mathrm{ha}^{-1}$ (Table 25). Placement caused lower $\mathrm{N}$ concentration in foliage than broadcast application at the second sampling (55 dap) in 1994 (Table 25).

In 1993, excluding the sampling at harvest,
Table 23. Effect of $\mathrm{N}$ rate on the total $\mathrm{N}$ concentration $\left(\mathrm{g} \mathrm{kg}^{-1} \mathrm{DM}\right)$ of carrot roots and shoots on different days after sowing (das) in 1994.

\begin{tabular}{|c|c|c|c|}
\hline \multirow[t]{2}{*}{$\mathrm{N}$ rate $\left(\mathrm{kg} \mathrm{ha}^{-1}\right)$} & \multicolumn{3}{|c|}{ Days after sowing } \\
\hline & 69 & 88 & 147 \\
\hline \multicolumn{4}{|l|}{ Shoots } \\
\hline 0 & 46.9 & $29.2^{\mathrm{b}}$ & $19.7^{\mathrm{b}}$ \\
\hline 30 & 46.2 & $30.8^{\mathrm{b}}$ & $21.1^{\mathrm{ab}}$ \\
\hline 70 & 45.1 & $32.8^{\mathrm{a}}$ & $22.2^{\mathrm{a}}$ \\
\hline 100 & 43.4 & $34.2^{\mathrm{a}}$ & $22.7^{\mathrm{a}}$ \\
\hline Probability $^{*}$ & ns & 0.001 & 0.061 \\
\hline
\end{tabular}

Roots

\begin{tabular}{rlcc}
0 & 18.0 & $11.2^{\mathrm{c}}$ & $8.6^{\mathrm{b}}$ \\
30 & 19.7 & $12.8^{\mathrm{ab}}$ & $10.3^{\mathrm{a}}$ \\
70 & 19.0 & $12.5^{\mathrm{b}}$ & $10.2^{\mathrm{a}}$ \\
100 & 18.5 & $13.8^{\mathrm{a}}$ & $11.4^{\mathrm{a}}$ \\
\hline Probability $^{*}$ & $\mathrm{~ns}$ & 0.009 & 0.011
\end{tabular}

$\mathrm{ns}=$ not significant $; \mathrm{P}>0.10$.

* Significance of difference between $\mathrm{N}$ rates on each sampling date. Means of $\mathrm{N}$ rates followed by no letter or a common letter do not differ significantly $(\mathrm{P}<0.05)$ according to the contrast test.

the $\mathrm{N}$ rate of $30 \mathrm{~kg} \mathrm{ha}^{-1}$ resulted in lower bulb $\mathrm{N}$ concentrations than $\mathrm{N}$ rates of $70 \mathrm{~kg} \mathrm{ha}^{-1}$ and 100 $\mathrm{kg} \mathrm{ha}^{-1}$ (Table 24). In addition, band placement resulted in higher bulb $\mathrm{N}$ concentrations than broadcasting in all samplings in 1993 (Table 24). In 1994, the $\mathrm{N}$ rate of $30 \mathrm{~kg} \mathrm{ha}^{-1}$ resulted in lower bulb $\mathrm{N}$ concentrations than $\mathrm{N}$ rates of $70 \mathrm{~kg}$ $\mathrm{ha}^{-1}$ and $100 \mathrm{~kg} \mathrm{ha}^{-1}$ (Table 25). At the second sampling (55 dap) in 1994, broadcasting led to higher bulb $\mathrm{N}$ concentrations than placement.

\subsubsection{Plant nitrogen uptake}

\section{Cabbage}

Plant $\mathrm{N}$ uptake in the non-fertilized treatments was 90, 159 and $117 \mathrm{~kg} \mathrm{ha}^{-1}$ in 1993, 1994 and 1995 , respectively. The highest $\mathrm{N}$ uptakes varied between years, being 311, 339 and $288 \mathrm{~kg}$ ha $^{-1}$ in 1993, 1994 and 1995, respectively. 


\section{AGRICULTURAL AND FOOD SCIENCE IN FINLAND}

\section{Salo, T. Effects of nitrogen fertilizer on growth of cabbage, carrot and onion}

Table 24. Effect of $\mathrm{N}$ rate and application method on total $\mathrm{N}$ concentrations $\left(\mathrm{g} \mathrm{kg}^{-1} \mathrm{DM}\right)$ in onion foliage and bulbs on different days after planting (dap) in 1993.

\begin{tabular}{|c|c|c|c|c|c|c|c|c|c|c|}
\hline \multirow[b]{3}{*}{ Dap } & & \multicolumn{5}{|c|}{$\mathrm{N}$ rate $\left(\mathrm{kg} \mathrm{ha}^{-1}\right)$} & \multirow{2}{*}{$\begin{array}{c}\text { Mean } \\
\text { (Method) }\end{array}$} & \multicolumn{3}{|c|}{ Significance $(\mathrm{P})$ of factors } \\
\hline & & 0 & & 30 & 70 & 100 & & $\mathrm{~N}$ rate & Method & Interact. \\
\hline & & \multicolumn{5}{|c|}{ Foliage N concentration } & & & & \\
\hline & & & 0 vs. $\mathrm{N}$ & & & & & & & \\
\hline \multirow[t]{3}{*}{34} & Broadcast & 37.4 & 0.028 & 38.4 & 40.7 & 40.5 & 39.9 & $\mathrm{~ns}$ & 0.010 & $\mathrm{~ns}$ \\
\hline & Placement & & 0.001 & 43.0 & 41.9 & 41.6 & 42.2 & & & \\
\hline & Mean ( $\mathrm{N}$ rate) & & & 40.7 & 41.3 & 41.1 & & & & \\
\hline \multirow[t]{3}{*}{57} & Broadcast & 20.9 & 0.001 & 25.1 & 29.7 & 29.2 & 28.0 & 0.005 & 0.001 & 0.072 \\
\hline & Placement & & 0.001 & 29.3 & 30.9 & 32.6 & 30.9 & & & \\
\hline & Mean ( $\mathrm{N}$ rate) & & & $27.2^{\mathrm{b}}$ & $30.3^{\mathrm{a}}$ & $30.8^{\mathrm{a}}$ & & & & \\
\hline \multirow[t]{3}{*}{83} & Broadcast & 18.2 & 0.008 & 21.5 & 23.1 & 23.6 & 22.7 & 0.007 & 0.001 & $\mathrm{~ns}$ \\
\hline & Placement & & 0.001 & 24.0 & 25.7 & 26.2 & 25.3 & & & \\
\hline & Mean ( $\mathrm{N}$ rate) & & & $22.7^{\mathrm{b}}$ & $24.4^{\mathrm{a}}$ & $24.9^{\mathrm{a}}$ & & & & \\
\hline \multirow[t]{4}{*}{98} & Broadcast & 15.9 & 0.150 & 17.9 & 19.1 & 19.0 & 18.7 & 0.053 & 0.001 & 0.040 \\
\hline & Placement & & 0.011 & 19.2 & 21.0 & 22.3 & 20.8 & & & \\
\hline & Mean (N rate) & & & 18.5 & 20.1 & 20.6 & & & & \\
\hline & & \multicolumn{5}{|c|}{ Bulb N concentration } & & & & \\
\hline \multirow[t]{3}{*}{34} & Broadcast & 15.4 & 0.034 & 16.3 & 19.6 & 20.2 & 18.7 & 0.045 & 0.001 & $\mathrm{~ns}$ \\
\hline & Placement & & 0.001 & 21.9 & 22.6 & 23.9 & 22.8 & & & \\
\hline & Mean ( $\mathrm{N}$ rate) & & & $19.1^{\mathrm{b}}$ & $21.1^{\mathrm{ab}}$ & $22.0^{\mathrm{a}}$ & & & & \\
\hline \multirow[t]{3}{*}{57} & Broadcast & 9.3 & 0.001 & 13.2 & 16.9 & 18.3 & 16.1 & 0.009 & 0.002 & $\mathrm{~ns}$ \\
\hline & Placement & & 0.001 & 17.5 & 19.8 & 20.9 & 19.4 & & & \\
\hline & Mean ( $\mathrm{N}$ rate) & & & $15.4^{\mathrm{b}}$ & $18.4^{\mathrm{a}}$ & $19.6^{\mathrm{a}}$ & & & & \\
\hline \multirow[t]{3}{*}{83} & Broadcast & 6.6 & 0.002 & 8.4 & 9.8 & 10.8 & 9.7 & 0.001 & 0.001 & $\mathrm{~ns}$ \\
\hline & Placement & & 0.001 & 9.8 & 12.7 & 13.5 & 11.9 & & & \\
\hline & Mean (N rate) & & & $9.1^{\mathrm{b}}$ & $11.1^{\mathrm{a}}$ & $12.1^{\mathrm{a}}$ & & & & \\
\hline \multirow[t]{3}{*}{98} & Broadcast & 7.7 & 0.001 & 10.7 & 11.2 & 10.8 & 10.9 & ns & 0.001 & 0.085 \\
\hline & Placement & & 0.001 & 11.9 & 14.5 & 14.4 & 13.6 & & & \\
\hline & Mean (N rate) & & & 11.3 & 12.8 & 12.6 & & & & \\
\hline
\end{tabular}

ns = not significant; $\mathrm{P}>0.10$. Means of $\mathrm{N}$ rates $30-100 \mathrm{~kg} \mathrm{ha}^{-1}$ followed by no letter or a common letter do not differ significantly $(\mathrm{P}<0.05)$ according to the contrast test.

Dap $=$ days after planting

0 vs. $\mathrm{N}=$ significance of difference between $0 \mathrm{~kg} \mathrm{ha}^{-1}$ and broadcast or placed $30-100 \mathrm{~kg} \mathrm{ha}^{-1}$. 


\section{AGRICULTURAL AND FOOD SCIENCE IN FINLAND}

Vol. 2 (1999): 157-232.

Table 25. Effect of $\mathrm{N}$ rate and application method on total $\mathrm{N}$ concentrations $\left(\mathrm{g} \mathrm{kg}^{-1} \mathrm{DM}\right)$ in onion foliage and bulbs on different days after planting (dap) in 1994

\begin{tabular}{|c|c|c|c|c|c|c|c|c|c|c|}
\hline \multirow[b]{3}{*}{ Dap } & & \multicolumn{5}{|c|}{$\mathrm{N}$ rate $\left(\mathrm{kg} \mathrm{ha}^{-1}\right)$} & \multirow{2}{*}{$\begin{array}{c}\text { Mean } \\
\text { (Method) }\end{array}$} & \multicolumn{3}{|c|}{ Significance $(\mathrm{P})$ of factors } \\
\hline & & 0 & & 30 & 70 & 100 & & $\mathrm{~N}$ rate & Method & Interact. \\
\hline & & \multicolumn{5}{|c|}{ Foliage $\mathrm{N}$ concentration } & \multirow{4}{*}{$\begin{array}{l}50.2 \\
51.3\end{array}$} & \multirow{4}{*}{0.001} & \multirow{4}{*}{ ns } & \multirow{4}{*}{ ns } \\
\hline \multirow{3}{*}{35} & & & 0 vs. N & & & & & & & \\
\hline & Broadcast & 43.6 & 0.007 & 47.2 & 51.2 & 52.3 & & & & \\
\hline & Placement & & 0.001 & 48.2 & 54.7 & 50.9 & & & & \\
\hline \multirow{4}{*}{55} & Mean ( $\mathrm{N}$ rate) & \multirow{3}{*}{31.8} & & $47.7^{\mathrm{b}}$ & $53.0^{\mathrm{a}}$ & $51.6^{\mathrm{a}}$ & & \multirow{3}{*}{0.036} & \multirow{3}{*}{0.002} & \multirow{3}{*}{ ns } \\
\hline & Broadcast & & 0.001 & 37.8 & 39.7 & 40.1 & 39.2 & & & \\
\hline & Placement & & 0.001 & 36.0 & 38.1 & 37.6 & 37.3 & & & \\
\hline & Mean ( $\mathrm{N}$ rate) & & & $36.9^{\mathrm{b}}$ & $38.9^{\mathrm{a}}$ & $38.9^{\mathrm{a}}$ & \multirow{3}{*}{29.0} & \multirow{3}{*}{0.001} & \multirow{3}{*}{ ns } & \multirow{3}{*}{$\mathrm{ns}$} \\
\hline \multirow[t]{2}{*}{78} & Broadcast & 26.6 & 0.003 & 26.7 & 29.6 & 30.7 & & & & \\
\hline & Placement & & 0.006 & 27.4 & 29.4 & 31.0 & & & & \\
\hline \multirow{4}{*}{105} & Mean ( $\mathrm{N}$ rate) & & & $27.1^{\mathrm{c}}$ & $29.5^{\mathrm{b}}$ & $30.8^{\mathrm{a}}$ & \multirow{4}{*}{$\begin{array}{l}29.1 \\
29.3\end{array}$} & \multirow{4}{*}{0.006} & \multirow{4}{*}{ ns } & \multirow{4}{*}{ ns } \\
\hline & Broadcast & 27.4 & 0.063 & 28.0 & 29.4 & 29.9 & & & & \\
\hline & Placement & & 0.025 & 27.8 & 29.4 & 31.0 & & & & \\
\hline & Mean ( $\mathrm{N}$ rate) & & & $27.9^{\mathrm{b}}$ & $29.8^{\mathrm{a}}$ & $29.9^{\mathrm{a}}$ & & & & \\
\hline \multirow{3}{*}{35} & & \multicolumn{5}{|c|}{ Bulb N concentration } & \multirow{3}{*}{$\begin{array}{l}22.1 \\
21.2\end{array}$} & \multirow{3}{*}{ ns } & & \\
\hline & Broadcast & 18.3 & 0.001 & 20.7 & 23.2 & 22.2 & & & 0.078 & 0.023 \\
\hline & Placement & & 0.015 & 20.6 & 20.3 & 22.7 & & & & \\
\hline & Mean ( $\mathrm{N}$ rate) & & & 20.7 & 21.8 & 22.5 & & & & \\
\hline 55 & Broadcast & 15.7 & 0.001 & 21.1 & 23.0 & 25.5 & 23.2 & 0.004 & 0.031 & ns \\
\hline & Placement & & 0.001 & 19.9 & 22.2 & 22.5 & 21.5 & & & \\
\hline & Mean ( $\mathrm{N}$ rate) & & & $20.5^{\mathrm{b}}$ & $22.6^{\mathrm{a}}$ & $24.0^{\mathrm{a}}$ & & & & \\
\hline 78 & Broadcast & 10.2 & 0.001 & 11.3 & 13.5 & 14.8 & 13.2 & 0.001 & ns & $\mathrm{ns}$ \\
\hline & Placement & & 0.001 & 11.0 & 13.9 & 14.4 & 13.1 & & & \\
\hline & Mean (N rate) & & & $11.1^{\mathrm{b}}$ & $13.7^{\mathrm{a}}$ & $14.6^{\mathrm{a}}$ & & & & \\
\hline 105 & Broadcast & 12.3 & 0.040 & 11.9 & 14.0 & 15.6 & 13.8 & 0.007 & ns & $\mathrm{ns}$ \\
\hline & Placement & & 0.030 & 12.4 & 14.2 & 15.5 & 14.0 & & & \\
\hline & Mean ( $\mathrm{N}$ rate) & & & $12.1^{\mathrm{b}}$ & $14.1^{\mathrm{a}}$ & $15.6^{\mathrm{a}}$ & & & & \\
\hline
\end{tabular}

$\mathrm{ns}=$ not significant; $\mathrm{P}>0.10$. Means of $\mathrm{N}$ rates $30-100 \mathrm{~kg} \mathrm{ha}^{-1}$ followed by no letter or a common letter do not differ significantly $(\mathrm{P}<0.05)$ according to the contrast test.

Dap $=$ days after planting

0 vs. $\mathrm{N}=$ significance of difference between $0 \mathrm{~kg} \mathrm{ha}^{-1}$ and broadcast or placed 30-100 kg ha-1. 


\section{AGRICULTURAL AND FOOD SCIENCE IN FINLAND}

Salo, T. Effects of nitrogen fertilizer on growth of cabbage, carrot and onion

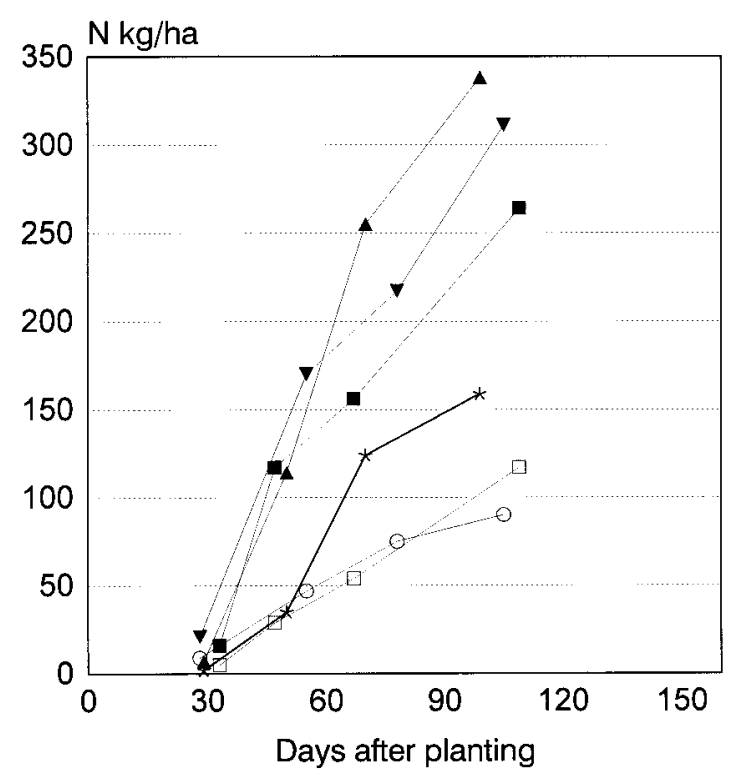

$\circ 0 \mathrm{~kg} / \mathrm{ha} 1993 \rightarrow$ Broadcast $250 \mathrm{~kg} / \mathrm{ha} 1993$

* $0 \mathrm{~kg} / \mathrm{ha} 1994$ - Broadcast $160 \mathrm{~kg} / \mathrm{ha} 1994$

$\because 0 \mathrm{~kg} / \mathrm{ha} 1995$ - Broadcast $160 \mathrm{~kg} / \mathrm{ha} 1995$

Fig. 11. N uptake rate for cabbage in 1993-1995.

Nitrogen uptake was low until the first sampling (28-33 dap), followed by a rapid increase until the second sampling (47-55 dap) in 1993 and 1995 or until the third sampling (70 dap) in 1994 (Fig. 11). Towards harvest N uptake continued at a slightly lower rate. Nitrogen uptake was less in the non-fertilized plots than in the fertilized treatments, excluding the placed treatments at the first sampling (28 dap) in 1994.

In 1993, broadcast application produced higher $\mathrm{N}$ uptake at the first sampling (28 dap) than placement application (Table 26). At the second sampling (55 dap), higher $\mathrm{N}$ rates led to higher $\mathrm{N}$ uptake. At the third sampling (78 dap), total $\mathrm{N}$ uptake was greater with high $\mathrm{N}$ rate in broadcast applications, but not in placement applications (interaction $\mathrm{P}=0.008$, data not shown). Distribution of $\mathrm{N}$ in plant showed that broadcast application produced more $\mathrm{N}$ allocation to the cabbage head than placement application. In addition, the $\mathrm{N}$ rate had an increasing effect on $\mathrm{N}$ uptake in the cabbage heads in the

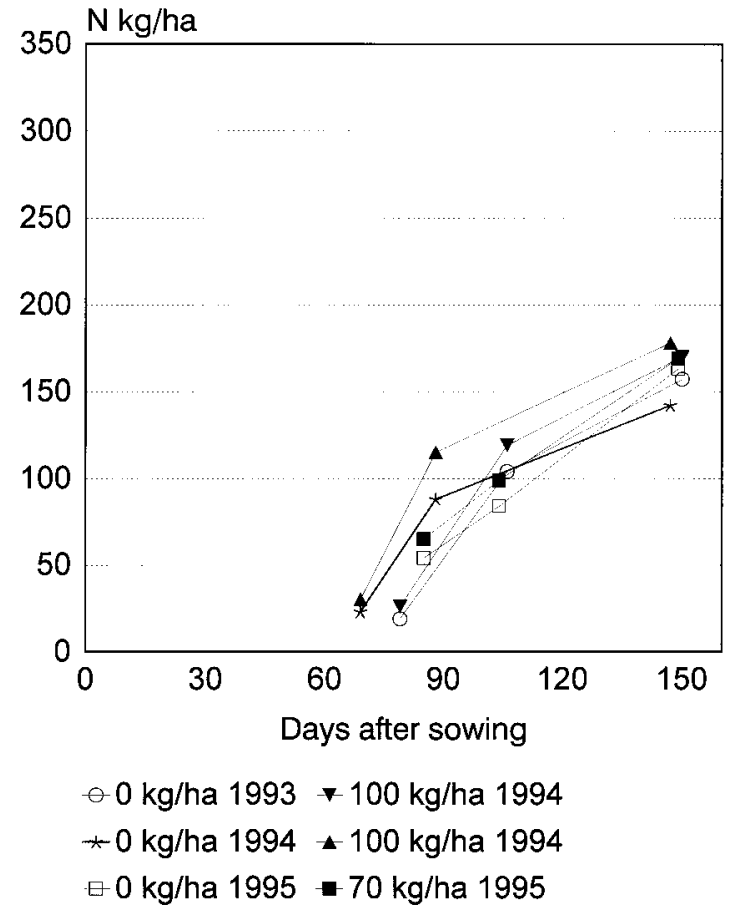

Fig. 12. N uptake rate for carrot in 1993-1995.

broadcast treatments. At harvest, the $\mathrm{N}$ rate had a clear effect on total above ground $\mathrm{N}$ uptake ( $\mathrm{P}$ $=0.002$, data not shown) as well as on the $\mathrm{N}$ uptake of leaves and heads. There was a slight interaction in total above ground plant $\mathrm{N}$ uptake, because $\mathrm{N}$ uptake was greater with high $\mathrm{N}$ rate in broadcast applications than in placement applications (interaction $\mathrm{P}=0.033$ ). This trend was also clear in the allocation of $\mathrm{N}$ to the heads. After the third sampling, there was practically no $\mathrm{N}$ uptake in non-fertilized and $125 \mathrm{~kg} \mathrm{ha}^{-1}$ fertilized treatments. The amount of $\mathrm{N}$ in the crop residues increased with $\mathrm{N}$ rate from an average $90 \mathrm{~kg} \mathrm{ha}^{-1}$ to $134 \mathrm{~kg} \mathrm{ha}^{-1}$.

In 1994, N uptake was greater with broadcast application at the first (29 dap) and second sampling (50 dap) than with placement application (Table 27). After that the differences between fertilized treatments were equalised. At harvest there was a slight interaction with higher $\mathrm{N}$ rates leading to higher head $\mathrm{N}$ uptake after broadcasting but not after placement of N. The 


\section{AGRICULTURAL AND FOOD SCIENCE IN FINLAND}

Vol. 2 (1999): 157-232.

Table 26. Effect of $\mathrm{N}$ rate and application method on the cabbage $\mathrm{N}$ uptake $\left(\mathrm{kg} \mathrm{ha}^{-1}\right)$ on different days after planting (dap) in 1993.

\begin{tabular}{|c|c|c|c|c|c|c|c|c|c|c|}
\hline \multirow[b]{2}{*}{ Dap } & \multirow[b]{2}{*}{ Sample } & \multirow[b]{2}{*}{0} & \multirow[b]{3}{*}{0 vs. $\mathrm{N}$} & \multicolumn{3}{|c|}{$\mathrm{N}$ rate $\left(\mathrm{kg} \mathrm{ha}^{-1}\right)$} & \multirow{2}{*}{$\begin{array}{c}\text { Mean } \\
\text { (Method) }\end{array}$} & \multicolumn{3}{|c|}{ Significance $(\mathrm{P})$ of factors } \\
\hline & & & & 125 & 188 & 250 & & $\mathrm{~N}$ rate & Method & Interact. \\
\hline \multirow[t]{4}{*}{28} & Tops & & & & & & & & & \\
\hline & Broadcast & 9 & 0.002 & 20 & 17 & 21 & 19 & ns & 0.003 & ns \\
\hline & Placement & & 0.018 & 12 & 13 & 14 & 13 & & & \\
\hline & Mean ( $\mathrm{N}$ rate) & & & 16 & 15 & 17 & & & & \\
\hline \multirow[t]{4}{*}{55} & Tops & & & & & & & & & \\
\hline & Broadcast & 47 & 0.001 & 136 & 148 & 170 & 151 & 0.022 & $\mathrm{~ns}$ & $\mathrm{~ns}$ \\
\hline & Placement & & 0.001 & 136 & 141 & 168 & 148 & & & \\
\hline & Mean ( $\mathrm{N}$ rate) & & & $136^{\mathrm{b}}$ & $145^{\mathrm{b}}$ & $169^{\mathrm{a}}$ & & & & \\
\hline \multirow[t]{8}{*}{78} & Leaves & & & & & & & & & \\
\hline & Broadcast & 42 & 0.001 & 87 & 150 & 127 & 121 & 0.055 & $\mathrm{~ns}$ & 0.071 \\
\hline & Placement & & 0.001 & 113 & 115 & 148 & 125 & & & \\
\hline & Mean ( $\mathrm{N}$ rate) & & & 100 & 132 & 137 & & & & \\
\hline & Heads & & & & & & & & & \\
\hline & Broadcast & 33 & 0.001 & 58 & 104 & 90 & 84 & 0.062 & 0.022 & 0.002 \\
\hline & Placement & & 0.001 & 76 & 68 & 72 & 72 & & & \\
\hline & Mean ( $\mathrm{N}$ rate) & & & 67 & 86 & 81 & & & & \\
\hline \multirow[t]{8}{*}{105} & Leaves & & & & & & & & & \\
\hline & Broadcast & 50 & 0.001 & 86 & 110 & 138 & 111 & 0.001 & ns & 0.090 \\
\hline & Placement & & 0.001 & 94 & 109 & 130 & 111 & & & \\
\hline & Mean ( $\mathrm{N}$ rate) & & & $90^{c}$ & $110^{\mathrm{b}}$ & $134^{\mathrm{a}}$ & & & & \\
\hline & Heads & & & & & & & & & \\
\hline & Broadcast & 40 & 0.001 & 93 & 127 & 173 & 131 & 0.004 & $\mathrm{~ns}$ & 0.042 \\
\hline & Placement & & 0.001 & 100 & 132 & 157 & 129 & & & \\
\hline & Mean ( $\mathrm{N}$ rate) & & & $97^{c}$ & $130^{\mathrm{b}}$ & $165^{\mathrm{a}}$ & & & & \\
\hline
\end{tabular}

$\mathrm{ns}=$ not significant $\mathrm{P}>0.10$. Means of $\mathrm{N}$ rates $125-250 \mathrm{~kg} \mathrm{ha}^{-1}$ followed by no letter or a common letter do not differ significantly $(\mathrm{P}<0.05)$ according to the contrast test.

Dap $=$ days after planting

0 vs. $\mathrm{N}=$ significance of difference between $0 \mathrm{~kg} \mathrm{ha}^{-1}$ and broadcast or placed $125-250 \mathrm{~kg} \mathrm{ha}^{-1}$.

$\mathrm{N}$ content in the crop residues of the fertilized plots averaged $153 \mathrm{~kg} \mathrm{ha}^{-1}$ (Table 27).

In $1995, \mathrm{~N}$ uptake was not affected by the method of application (data not shown). Nitrogen uptake of the $\mathrm{N}$ fertilized treatments averaged $276 \mathrm{~kg} \mathrm{ha}^{-1}$, from which an average $135 \mathrm{~kg}$ $\mathrm{ha}^{-1}$ was in crop residues.

\section{Carrot}

Plant uptake of $\mathrm{N}$ varied from 135 to $170 \mathrm{~kg} \mathrm{ha}^{-1}$ and from 142 to $178 \mathrm{~kg} \mathrm{ha}^{-1}$ in 1993 and 1994 , respectively. In 1995, the average uptake of $\mathrm{N}$ was $166 \mathrm{~kg} \mathrm{ha}^{-1}$. The amount of $\mathrm{N}$ in the storage roots increased rapidly from the middle of July 


\section{AGRICULTURAL AND FOOD SCIENCE IN FINLAND}

Salo, T. Effects of nitrogen fertilizer on growth of cabbage, carrot and onion

Table 27. Effect of $\mathrm{N}$ rate and application method on the cabbage $\mathrm{N}$ uptake $\left(\mathrm{kg} \mathrm{ha}^{-1}\right)$ on different days after planting (dap) in 1994.

\begin{tabular}{|c|c|c|c|c|c|c|c|c|c|c|}
\hline \multirow[b]{2}{*}{ Dap } & \multirow[b]{2}{*}{ Sample } & \multirow[b]{2}{*}{0} & \multirow[b]{3}{*}{0 vs. $\mathrm{N}$} & \multicolumn{3}{|c|}{$\mathrm{N}$ rate $\left(\mathrm{kg} \mathrm{ha}^{-1}\right)$} & \multirow{2}{*}{$\begin{array}{c}\text { Mean } \\
\text { (Method) }\end{array}$} & \multicolumn{3}{|c|}{ Significance $(\mathrm{P})$ of factors } \\
\hline & & & & 80 & 120 & 160 & & $\mathrm{~N}$ rate & Method & Interact \\
\hline \multirow[t]{4}{*}{29} & Tops & & & & & & & & & \\
\hline & Broadcast & 2 & 0.002 & 6 & 7 & 7 & 7 & ns & 0.001 & ns \\
\hline & Placement & & 0.094 & 2 & 3 & 3 & 3 & & & \\
\hline & Mean ( $\mathrm{N}$ rate) & & & 4 & 5 & 5 & & & & \\
\hline \multirow[t]{4}{*}{50} & Tops & & & & & & & & & \\
\hline & Broadcast & 35 & 0.001 & 100 & 126 & 114 & 113 & ns & 0.045 & ns \\
\hline & Placement & & 0.001 & 94 & 101 & 97 & 97 & & & \\
\hline & Mean ( $\mathrm{N}$ rate) & & & 97 & 113 & 105 & & & & \\
\hline \multirow[t]{8}{*}{70} & Leaves & & & & & & & & & \\
\hline & Broadcast & 87 & 0.001 & 129 & 153 & 176 & 153 & ns & ns & $\mathrm{ns}$ \\
\hline & Placement & & 0.001 & 151 & 155 & 159 & 155 & & & \\
\hline & Mean ( $\mathrm{N}$ rate) & & & 140 & 154 & 168 & & & & \\
\hline & Heads & & & & & & & & & \\
\hline & Broadcast & 38 & 0.004 & 60 & 70 & 79 & 69 & ns & ns & $\mathrm{ns}$ \\
\hline & Placement & & 0.005 & 62 & 66 & 65 & 64 & & & \\
\hline & Mean (N rate) & & & 61 & 68 & 72 & & & & \\
\hline \multirow[t]{8}{*}{99} & Leaves & & & & & & & & & \\
\hline & Broadcast & 74 & 0.001 & 127 & 164 & 159 & 150 & ns & ns & ns \\
\hline & Placement & & 0.001 & 147 & 160 & 161 & 156 & & & \\
\hline & Mean ( $\mathrm{N}$ rate) & & & 137 & 162 & 160 & & & & \\
\hline & Heads & & & & & & & & & \\
\hline & Broadcast & 85 & 0.001 & 136 & 170 & 180 & 162 & 0.059 & ns & 0.078 \\
\hline & Placement & & 0.001 & 181 & 160 & 165 & & & & \\
\hline & Mean (N rate) & & & 145 & 175 & 170 & & & & \\
\hline
\end{tabular}

$\mathrm{ns}=$ not significant; $\mathrm{P}>0.10$. Means of $\mathrm{N}$ rates $80-160 \mathrm{~kg} \mathrm{ha}^{-1}$ followed by no letter or a common letter do not differ significantly $(\mathrm{P}<0.05)$ according to the contrast test.

Dap $=$ days after planting

0 vs. $\mathrm{N}=$ significance of difference between $0 \mathrm{~kg} \mathrm{ha}^{-1}$ and broadcast or placed $80-160 \mathrm{~kg} \mathrm{ha}^{-1}$.

until harvest (Fig. 12). Nitrogen uptake in shoots was about $20 \mathrm{~kg} \mathrm{ha}^{-1}$ towards the end of June. The content of $\mathrm{N}$ in shoots increased up to $40 \mathrm{~kg}$ $\mathrm{ha}^{-1}$ during July, but then $\mathrm{N}$ uptake started to slow down in August. In 1994, nitrogen uptake at the second sampling was lower in non-fertilized than in fertilized plots ( $\mathrm{P}=0.043$, data not shown). At harvest, the shoots contained 35-39\%, 32$34 \%$ and $32-33 \%$ of the total plant $\mathrm{N}$ in 1993 , 1994 and 1995, respectively. 


\section{AGRICULTURAL AND FOOD SCIENCE IN FINLAND}

Vol. 2 (1999): 157-232.

Onion

Plant $\mathrm{N}$ uptake in the non-fertilized treatments was 48, 81 and $26 \mathrm{~kg} \mathrm{ha}^{-1}$ in 1993, 1994 and 1995, respectively. The highest plant $\mathrm{N}$ uptakes in each year were 140, 128 and $60 \mathrm{~kg} \mathrm{ha}^{-1}$ in 1993, 1994 and 1995, respectively (Fig. 13). Nitrogen uptake in the bulb increased exponentially during the growing season (Tables 28 and 29). Foliage $\mathrm{N}$ decreased after the third sampling (70-83 dap). At harvest the foliage contained 24-28\% of total plant N uptake in 1993, 26-37\% in 1994 and $22-25 \%$ in 1995 . In each year, $N$ uptake was lower without $\mathrm{N}$ than with $\mathrm{N}$ fertilizer.

In 1993, $\mathrm{N}$ uptake increased at the third sampling (83 dap) and at harvest with increasing $\mathrm{N}$ rates. At the first (35 dap), third (78 dap) and fourth sampling (105 dap) in 1993, N uptake was higher when fertilizer was placed compared to broadcasting (Table 28). In 1994, the $\mathrm{N}$ rate and application method had little effect on $\mathrm{N}$ uptake (Table 29). At the third and fourth sampling, N uptake in the bulbs was less with the $\mathrm{N}$ rate of $30 \mathrm{~kg} \mathrm{ha}^{-1}$ than with higher $\mathrm{N}$ rates. In addition, there was an interaction at harvest in 1994, when $\mathrm{N}$ uptake in the foliage increased by high $\mathrm{N}$ rates in the broadcast application but not in the placement application.

\subsubsection{Apparent recovery of fertilizer nitrogen}

\section{Cabbage}

The apparent recoveries of fertilizer $\mathrm{N}$ in cabbage plants varied from 0.71 to 0.88 in 1993, from 1.01 to 1.79 in 1994 (Table 30) and from 0.82 to 1.39 in 1995 (data not shown). There were no statistically significant differences between treatments.

\section{Carrot}

In 1993, as a result of high $\mathrm{N}$ uptakes from nonfertilized plots apparent recovery values were often not applicable (value less than zero). The

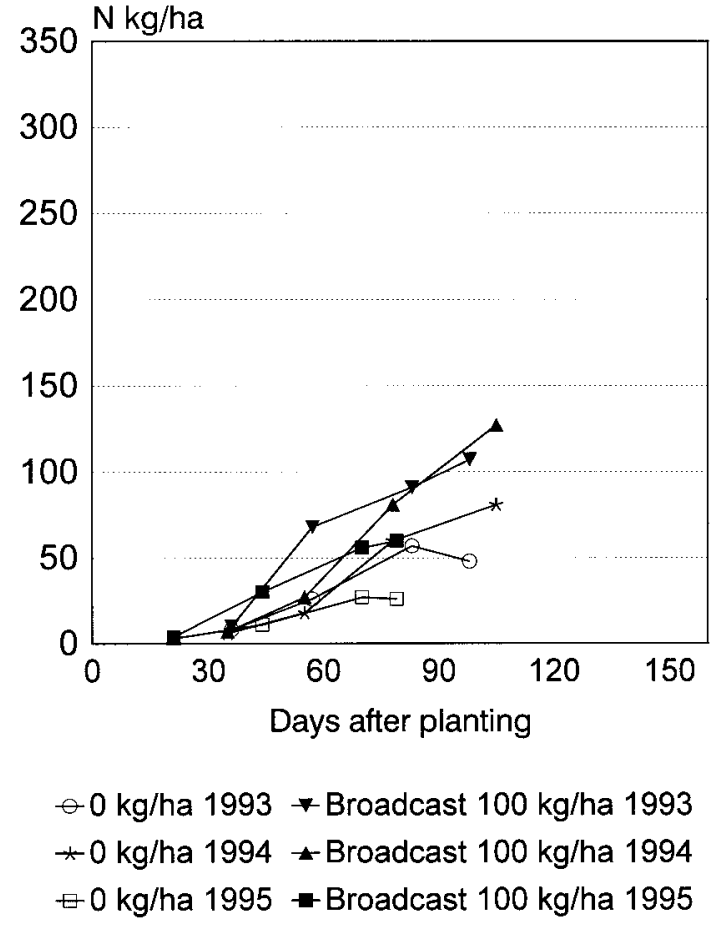

Fig. 13. N uptake rate for onion in 1993-1995.

$\mathrm{N}$ uptake without $\mathrm{N}$ fertilizer was commonly higher than with $\mathrm{N}$ fertilizer. In 1994, the apparent recovery of $\mathrm{N}$ varied from 0.27 to 0.85 , but in this year too, $25 \%$ of the plots gave negative $\mathrm{N}$ recovery values. In 1994, there were no differences in apparent recovery values between $\mathrm{N}$ rates (data not shown). In 1995, two out of four apparent recovery values were also below zero.

\section{Onion}

The apparent recovery of $\mathrm{N}$ was clearly higher with band placement in 1993 (Table 31). The apparent recovery of $\mathrm{N}$ decreased from 1.05 to 0.59 in the broadcast treatments and from 1.78 to 0.92 in the placement treatments when the $\mathrm{N}$ 


\section{AGRICULTURAL AND FOOD SCIENCE IN FINLAND}

Salo, T. Effects of nitrogen fertilizer on growth of cabbage, carrot and onion

Table 28. Effect of $\mathrm{N}$ rate and application method on the onion $\mathrm{N}$ uptake $\left(\mathrm{kg} \mathrm{ha}^{-1}\right)$ on different days after planting (dap) in 1993.

\begin{tabular}{|c|c|c|c|c|c|c|c|c|c|c|}
\hline \multirow[b]{3}{*}{ Dap } & & & & \multicolumn{3}{|c|}{$\mathrm{N}$ rate $\left(\mathrm{kg} \mathrm{ha}^{-1}\right)$} & \multirow{2}{*}{$\begin{array}{c}\text { Mean } \\
\text { (Method) }\end{array}$} & \multicolumn{3}{|c|}{ Significance $(\mathrm{P})$ of factors } \\
\hline & & \multicolumn{2}{|l|}{0} & 30 & 70 & 100 & & $\mathrm{~N}$ rate & Method & Interact. \\
\hline & & & & \multicolumn{3}{|c|}{ Foliage N uptake } & & & & \\
\hline & & & 0 vs. $\mathrm{N}$ & & & & & & & \\
\hline \multirow[t]{3}{*}{34} & Broadcast & 6 & 0.077 & 6 & 7 & 8 & 7 & ns & 0.002 & ns \\
\hline & Placement & & 0.006 & 9 & 10 & 9 & 9 & & & \\
\hline & Mean (N rate) & & & & & & & & & \\
\hline \multirow[t]{3}{*}{57} & Broadcast & 20 & 0.004 & 31 & 34 & 37 & 34 & ns & ns & ns \\
\hline & Placement & & 0.001 & 38 & 37 & 31 & 35 & & & \\
\hline & Mean (N rate) & & & 34 & 36 & 34 & & & & \\
\hline \multirow[t]{3}{*}{83} & Broadcast & 35 & 0.006 & 39 & 51 & 54 & 48 & 0.002 & 0.001 & ns \\
\hline & Placement & & 0.001 & 53 & 57 & 68 & 59 & & & \\
\hline & Mean (N rate) & & & $46^{\mathrm{c}}$ & $54^{\mathrm{b}}$ & $61^{\mathrm{a}}$ & & & & \\
\hline \multirow[t]{4}{*}{98} & Broadcast & 13 & 0.028 & 20 & 25 & 29 & 25 & 0.001 & 0.001 & ns \\
\hline & Placement & & 0.010 & 26 & 33 & 39 & 33 & & & \\
\hline & Mean (N rate) & & & $23^{\mathrm{c}}$ & $29^{b}$ & $34^{\mathrm{a}}$ & & & & \\
\hline & & & & \multicolumn{3}{|c|}{ Bulb N uptake } & & & & \\
\hline \multirow[t]{3}{*}{34} & Broadcast & 2 & ns & 2 & 2 & 2 & 2 & 0.066 & 0.001 & 0.084 \\
\hline & Placement & & 0.002 & 2 & 3 & 3 & 3 & & & \\
\hline & Mean (N rate) & & & 2 & 3 & 3 & & & & \\
\hline \multirow[t]{3}{*}{57} & Broadcast & 6 & 0.015 & 7 & 9 & 10 & 9 & ns & 0.047 & ns \\
\hline & Placement & & 0.001 & 10 & 12 & 10 & 10 & & & \\
\hline & Mean (N rate) & & & 8 & 11 & 10 & & & & \\
\hline \multirow[t]{3}{*}{83} & Broadcast & 22 & 0.001 & 28 & 33 & 37 & 33 & 0.001 & 0.001 & $\mathrm{~ns}$ \\
\hline & Placement & & 0.001 & 37 & 44 & 49 & 44 & & & \\
\hline & Mean (N rate) & & & $33^{\mathrm{c}}$ & $39^{b}$ & $43^{\mathrm{a}}$ & & & & \\
\hline \multirow[t]{3}{*}{98} & Broadcast & 35 & 0.001 & 60 & 68 & 78 & 68 & 0.004 & 0.001 & ns \\
\hline & Placement & & 0.001 & 76 & 98 & 101 & 91 & & & \\
\hline & Mean (N rate) & & & $68^{\mathrm{b}}$ & $83^{\mathrm{a}}$ & $89^{\mathrm{a}}$ & & & & \\
\hline
\end{tabular}

$\mathrm{ns}=$ not significant; $\mathrm{P}>0.10$. Means of $\mathrm{N}$ rates $30-100 \mathrm{~kg} \mathrm{ha}^{-1}$ followed by no letter or a common letter do not differ significantly $(\mathrm{P}<0.05)$ according to the contrast test.

Dap $=$ days after planting

0 vs. $\mathrm{N}=$ significance of difference between $0 \mathrm{~kg} \mathrm{ha}^{-1}$ and broadcast or placed $30-100 \mathrm{~kg} \mathrm{ha}^{-1}$. 


\section{AGRICULTURAL AND FOOD SCIENCE IN FINLAND}

Vol. 2 (1999): 157-232.

Table 29. Effect of $\mathrm{N}$ rate and application method on the onion $\mathrm{N}$ uptake $\left(\mathrm{kg} \mathrm{ha}^{-1}\right)$ on different days after planting (dap) in 1994

\begin{tabular}{|c|c|c|c|c|c|c|c|c|c|c|}
\hline \multirow[b]{3}{*}{ Dap } & & & & \multicolumn{3}{|c|}{$\mathrm{N}$ rate $\left(\mathrm{kg} \mathrm{ha}^{-1}\right)$} & \multirow{2}{*}{$\begin{array}{c}\text { Mean } \\
\text { (Method) }\end{array}$} & \multicolumn{3}{|c|}{ Significance $(\mathrm{P})$ of factors } \\
\hline & & \multicolumn{2}{|l|}{0} & 30 & 70 & 100 & & $\mathrm{~N}$ rate & Method & Interact. \\
\hline & & & & \multicolumn{3}{|c|}{ Foliage $\mathrm{N}$ uptake } & & & & \\
\hline & & & 0 vs. $\mathrm{N}$ & & & & & & & \\
\hline \multirow[t]{3}{*}{35} & Broadcast & 4 & 0.048 & 4 & 4 & 5 & 5 & ns & ns & ns \\
\hline & Placement & & 0.017 & 5 & 5 & 6 & 5 & & & \\
\hline & Mean ( $\mathrm{N}$ rate) & & & 5 & 5 & 6 & & & & \\
\hline \multirow[t]{3}{*}{55} & Broadcast & 15 & 0.001 & 19 & 19 & 22 & 20 & ns & ns & ns \\
\hline & Placement & & 0.005 & 21 & 19 & 20 & 20 & & & \\
\hline & Mean ( $\mathrm{N}$ rate) & & & 20 & 19 & 21 & & & & \\
\hline \multirow[t]{3}{*}{78} & Broadcast & 35 & ns & 39 & 42 & 45 & 42 & ns & ns & ns \\
\hline & Placement & & 0.092 & 43 & 46 & 38 & 42 & & & \\
\hline & Mean ( $\mathrm{N}$ rate) & & & 41 & 44 & 42 & & & & \\
\hline \multirow[t]{4}{*}{105} & Broadcast & 24 & 0.048 & 27 & 28 & 37 & 30 & ns & ns & 0.038 \\
\hline & Placement & & 0.038 & 37 & 31 & 33 & 34 & & & \\
\hline & Mean ( $\mathrm{N}$ rate) & & & 32 & 29 & 35 & & & & \\
\hline & & & & \multicolumn{3}{|c|}{ Bulb N uptake } & & & & \\
\hline \multirow[t]{3}{*}{35} & Broadcast & 2 & $\mathrm{~ns}$ & 2 & 2 & 2 & 2 & ns & ns & ns \\
\hline & Placement & & ns & 2 & 2 & 3 & 2 & & & \\
\hline & Mean (N rate) & & & 2 & 2 & 3 & & & & \\
\hline \multirow[t]{3}{*}{55} & Broadcast & 3 & 0.001 & 4 & 4 & 5 & 5 & ns & $\mathrm{ns}$ & ns \\
\hline & Placement & & 0.001 & 5 & 5 & 5 & 5 & & & \\
\hline & Mean ( $\mathrm{N}$ rate) & & & 5 & 5 & 5 & & & & \\
\hline \multirow[t]{3}{*}{78} & Broadcast & 25 & 0.012 & 28 & 31 & 36 & 32 & 0.010 & ns & ns \\
\hline & Placement & & 0.008 & 28 & 34 & 32 & 31 & & & \\
\hline & Mean (N rate) & & & $28^{\mathrm{b}}$ & $33^{\mathrm{a}}$ & $34^{\mathrm{a}}$ & & & & \\
\hline \multirow[t]{3}{*}{105} & Broadcast & 57 & 0.032 & 58 & 80 & 90 & 76 & 0.050 & ns & ns \\
\hline & Placement & & 0.052 & 64 & 73 & 75 & 71 & & & \\
\hline & Mean ( $\mathrm{N}$ rate) & & & $61^{\mathrm{b}}$ & $76^{\mathrm{ab}}$ & $83^{\mathrm{a}}$ & & & & \\
\hline
\end{tabular}

$\mathrm{ns}=$ not significant; $\mathrm{P}>0.10$. Means of $\mathrm{N}$ rates $30-100 \mathrm{~kg} \mathrm{ha}^{-1}$ followed by no letter or a common letter do not differ significantly $(\mathrm{P}<0.05)$ according to the contrast test.

Dap $=$ days after planting

0 vs. $\mathrm{N}=$ significance of difference between $0 \mathrm{~kg} \mathrm{ha}^{-1}$ and broadcast or placed $30-100 \mathrm{~kg} \mathrm{ha}^{-1}$. 


\section{AGRICULTURAL AND FOOD SCIENCE IN FINLAND}

Salo, T. Effects of nitrogen fertilizer on growth of cabbage, carrot and onion

Table 30. Effect of $\mathrm{N}$ rate and application method on the apparent recovery of fertilizer nitrogen for cabbage in 19931994.

\begin{tabular}{|c|c|c|c|c|}
\hline \multirow[b]{2}{*}{ Year } & \multirow[b]{2}{*}{$\mathrm{N}$ rate $\left(\mathrm{kg} \mathrm{ha}^{-1}\right)$} & \multicolumn{2}{|c|}{ Application method } & \multirow[b]{2}{*}{$\begin{array}{c}\text { Mean } \\
\text { ( } \mathrm{N} \text { rate) }\end{array}$} \\
\hline & & Broadcast & Placement & \\
\hline \multirow[t]{3}{*}{1993} & 125 & 0.71 & 0.83 & 0.77 \\
\hline & 188 & 0.78 & 0.80 & 0.79 \\
\hline & 250 & 0.88 & 0.79 & 0.84 \\
\hline \multicolumn{2}{|c|}{ Mean (Method) } & 0.79 & 0.81 & \\
\hline & \multicolumn{2}{|l|}{ Probability* } & & \\
\hline & $\mathrm{N}$ rate & ns & & \\
\hline & Method & ns & & \\
\hline & Interaction & 0.100 & & \\
\hline 1994 & $\mathrm{~N}$ rate $\left(\mathrm{kg} \mathrm{ha}^{-1}\right)$ & Broadcast & Placement & $\begin{array}{c}\text { Mean } \\
\text { (N rate) }\end{array}$ \\
\hline & 80 & 1.30 & 1.79 & 1.55 \\
\hline & 120 & 1.46 & 1.51 & 1.49 \\
\hline & 160 & 1.12 & 1.01 & 1.07 \\
\hline \multicolumn{2}{|c|}{ Mean (Method) } & 1.30 & 1.44 & \\
\hline & \multicolumn{2}{|l|}{ Probability $^{*}$} & & \\
\hline & $\mathrm{N}$ rate & ns & & \\
\hline & Method & ns & & \\
\hline & Interaction & ns & & \\
\hline
\end{tabular}

ns = not significant, $(\mathrm{P}>0.10)$.

*Significance of difference between $\mathrm{N}$ rates and application methods.

rate was increased from $30 \mathrm{~kg} \mathrm{ha}^{-1}$ to $100 \mathrm{~kg}$ $\mathrm{ha}^{-1}$. Apparent recovery of $\mathrm{N}$ decreased with high $\mathrm{N}$ rates in both application methods. In 1994, soil mineralisation was so high that $\mathrm{N}$ uptake from some of the non-fertilized plots was even higher than from the $30 \mathrm{~kg} \mathrm{ha}^{-1}$ fertilized plots. Placement of $30 \mathrm{~kg} \mathrm{ha}^{-1} \mathrm{~N}$ caused higher apparent recovery of $\mathrm{N}$ than broadcasting of $30 \mathrm{~kg} \mathrm{ha}^{-1} \mathrm{~N}$ (Table 31). In 1995, the apparent recovery of $\mathrm{N}$ was low, on average 0.33 , due to the low growth.
Table 31. Effect of $\mathrm{N}$ rate and application method on the apparent recovery of fertilizer nitrogen for onion in 19931994.

\begin{tabular}{|c|c|c|c|c|}
\hline \multirow[b]{2}{*}{ Year } & \multirow[b]{2}{*}{$\mathrm{N}$ rate $\left(\mathrm{kg} \mathrm{ha}^{-1}\right)$} & \multicolumn{2}{|c|}{ Application method } & \multirow[b]{2}{*}{$\begin{array}{c}\text { Mean } \\
\text { ( } \mathrm{N} \text { rate) }\end{array}$} \\
\hline & & Broadcast & Placement & \\
\hline \multirow[t]{3}{*}{1993} & 30 & 1.05 & 1.78 & $1.41^{\mathrm{a}}$ \\
\hline & 70 & 0.64 & 1.18 & $0.91^{\mathrm{b}}$ \\
\hline & 100 & 0.59 & 0.92 & $0.76^{\mathrm{c}}$ \\
\hline \multicolumn{2}{|c|}{ Mean (Method) } & 0.76 & 1.29 & \\
\hline & Probability $^{*}$ & & & \\
\hline & $\mathrm{N}$ rate & 0.001 & & \\
\hline & Method & 0.001 & & \\
\hline & Interaction & ns & & \\
\hline 1994 & $\mathrm{~N}$ rate $\left(\mathrm{kg} \mathrm{ha}^{-1}\right)$ & Broadcast & Placement & $\begin{array}{c}\text { Mean } \\
\text { (N rate) }\end{array}$ \\
\hline & 30 & 0.32 & 0.73 & 0.53 \\
\hline & 70 & 0.38 & 0.33 & 0.35 \\
\hline & 100 & 0.46 & 0.29 & 0.37 \\
\hline \multicolumn{2}{|c|}{ Mean (Method) } & 0.39 & 0.45 & \\
\hline & Probability $^{*}$ & & & \\
\hline & $\mathrm{N}$ rate & ns & & \\
\hline & Method & ns & & \\
\hline & Interaction & 0.066 & & \\
\hline
\end{tabular}

ns = not significant, $(\mathrm{P}>0.10)$.

*Significance of difference between $\mathrm{N}$ rates and application methods. Means of $\mathrm{N}$ rates followed by no letter or a common letter do not differ significantly $(\mathrm{P}<0.05)$ according to the contrast test.

\subsection{Interaction between nitrogen uptake and sample yield}

When fresh sample yield increased, $\mathrm{N}$ uptake increased with all crops studied (Figs. 14-16). However, the variation of $\mathrm{N}$ uptake at the same yield level was considerable. When a linear equation through the origin was fitted to the fresh yield data, the following equations were obtained: 
Vol. 2 (1999): 157-232.

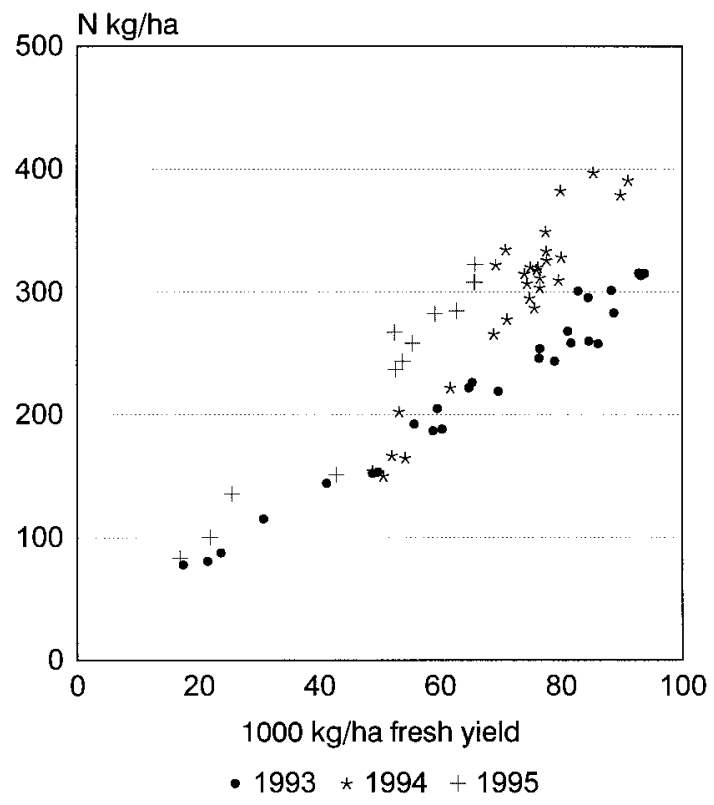

Fig. 14. Cabbage head yield vs. N uptake at harvest in 1993 1995.

Cabbage:

$\mathrm{N}$ uptake $\left(\mathrm{kg} \mathrm{ha}^{-1}\right)=3.8 \times$ Yield $\left(\mathrm{t} \mathrm{ha}^{-1}\right)$;

$$
\left(R^{2}=0.764, n=68\right)
$$

Carrot:

$\mathrm{N}$ uptake $\left(\mathrm{kg} \mathrm{ha}^{-1}\right)=1.6 \times$ Yield $\left(\mathrm{t} \mathrm{ha}^{-1}\right)$;

$$
\left(\mathrm{R}^{2}=0.170, \mathrm{n}=42\right)
$$

Onion:

$\mathrm{N}$ uptake $\left(\mathrm{kg} \mathrm{ha}^{-1}\right)=2.5 \times$ Yield $\left(\mathrm{t} \mathrm{ha}^{-1}\right)$

$$
\left(\mathrm{R}^{2}=0.485, \mathrm{n}=64\right)
$$

When the sampled dry matter yield was compared to the $\mathrm{N}$ uptake, the following linear equations were obtained:

Cabbage:

$\mathrm{N}$ uptake $\left(\mathrm{kg} \mathrm{ha}^{-1}\right)=0.022 \mathrm{x}$ Dry matter $\left(\mathrm{kg} \mathrm{ha}^{-1}\right)$;

$$
\left(R^{2}=0.685, n=68\right)
$$

Carrot:

$\mathrm{N}$ uptake $\left(\mathrm{kg} \mathrm{ha}^{-1}\right)=0.011 \times$ Dry matter $\left(\mathrm{kg} \mathrm{ha}^{-1}\right)$;

Onion:

$$
\left(\mathrm{R}^{2}=0.293, \mathrm{n}=42\right)
$$

$\mathrm{N}$ uptake $\left(\mathrm{kg} \mathrm{ha}^{-1}\right)=0.015 \mathrm{x}$ Dry matter $\left(\mathrm{kg} \mathrm{ha}^{-1}\right)$; $\left(\mathrm{R}^{2}=0.670, \mathrm{n}=64\right)$

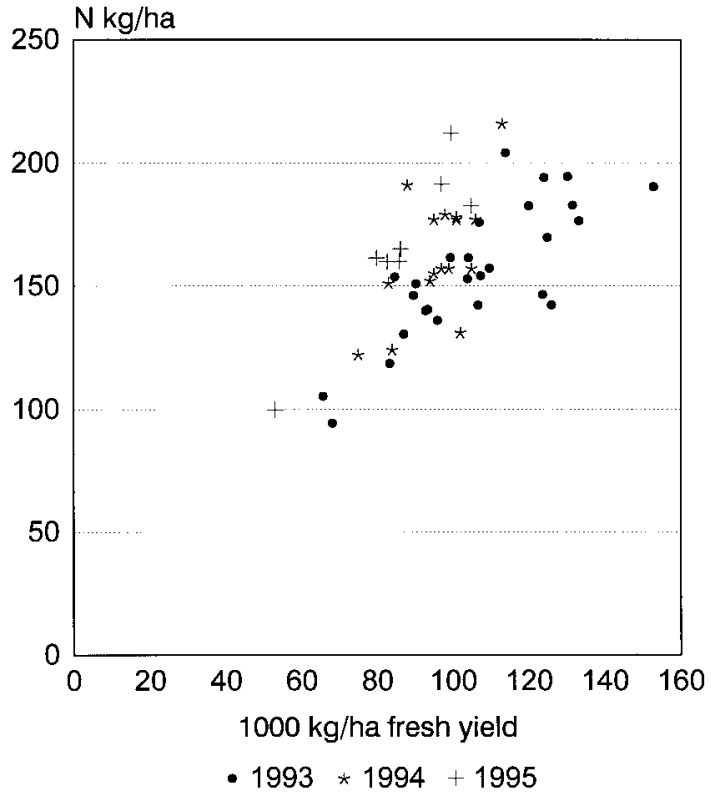

Fig. 15. Carrot root yield vs. N uptake at harvest in 1993 1995 .

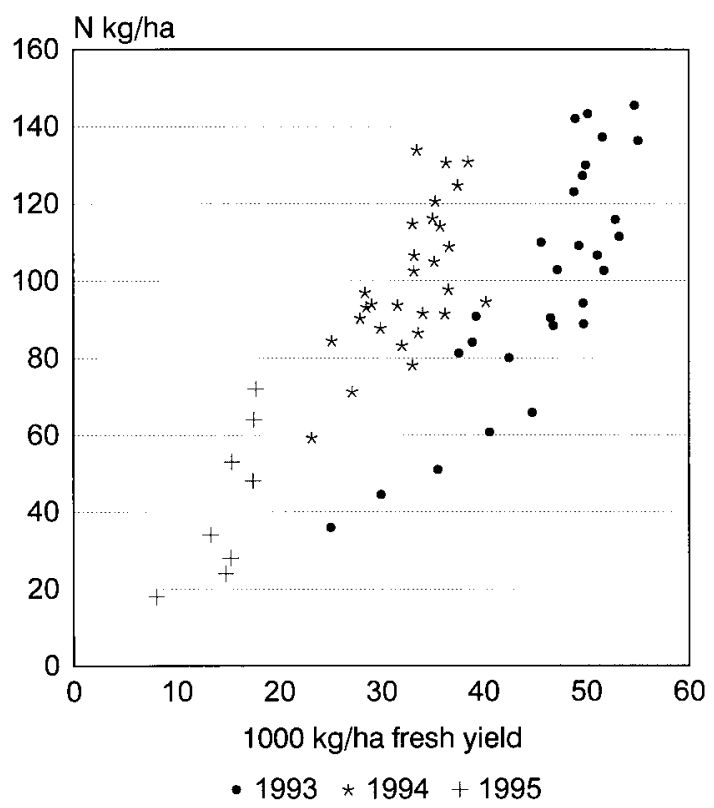

Fig. 16. Onion bulb yield vs. N uptake at harvest in 1993 1995. 


\section{AGRICULTURAL AND FOOD SCIENCE IN FINLAND}

Salo, T. Effects of nitrogen fertilizer on growth of cabbage, carrot and onion

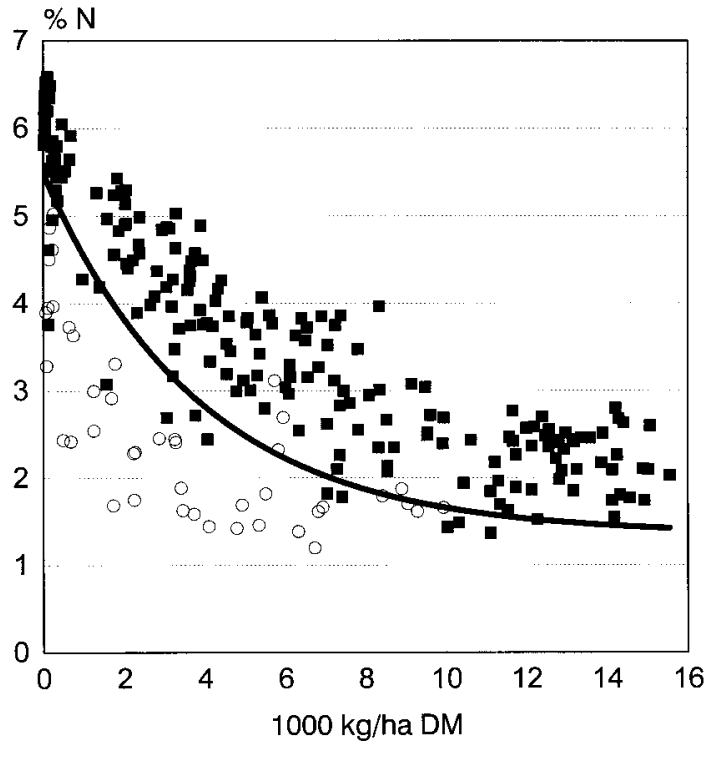

- Fertilized o Non-fertilized -Model

Fig. 17. Cabbage dry weight vs. N concentration in 19931995.

\subsection{Interaction between dry matter accumulation and nitrogen concentration}

Non-fertilized plants had lower $\mathrm{N}$ concentrations $(\mathrm{P}<0.05$, confidence intervals) than $\mathrm{N}$ fertilized plants at the same dry weight in cabbage (Fig. 17) and onion (Fig. 19), but there was no difference between carrot treatments (Fig. 18).

The critical N\% concentration equation suggested for cabbage by Greenwood and Draycott (1989) and supported by Guttormsen and Riley (1996) was located between the non-fertilized and fertilized plant $\mathrm{N}$ concentrations (Fig. 17). Equations from experimental data produced the following coefficients with a $95 \%$ confidence interval for cabbage:

Model B $=3.00$ (Greenwood and Draycott 1989)

$\mathrm{N} 0 \mathrm{~kg} \mathrm{ha}^{-1}: \mathrm{B}=2.14(1.86-2.42) ; \mathrm{n}=47$

$\mathrm{N}$ fertilized : $\mathrm{B}=3.80(3.66-3.94) ; \mathrm{n}=223$

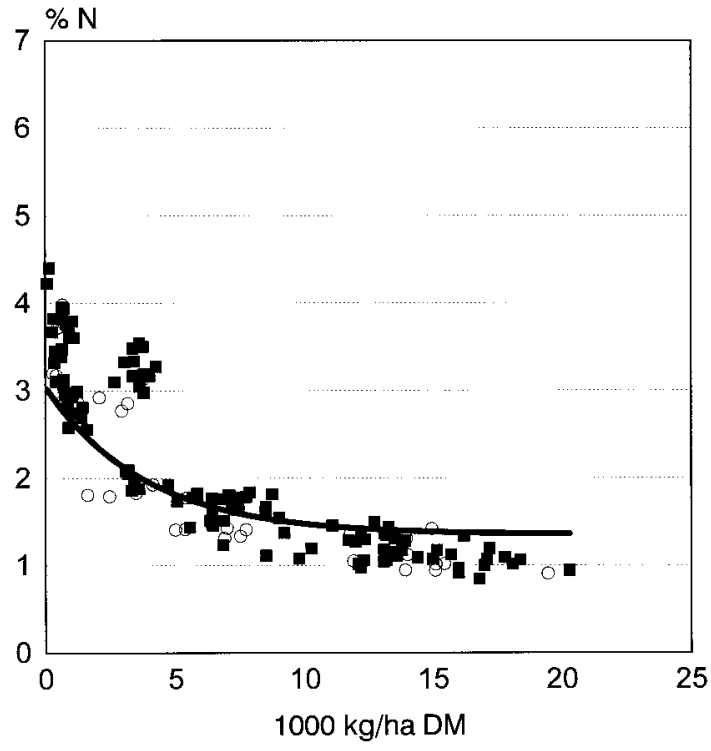

- Fertilized o Non-fertilized -Model

Fig. 18. Carrot dry weight vs. N concentration in 19931995.

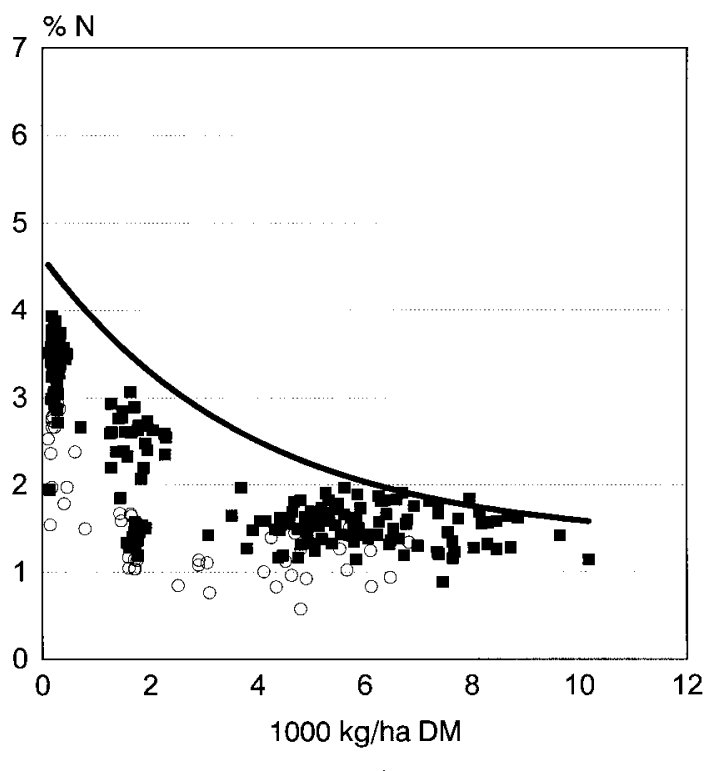

- Fertilized o Non-fertilized -Model

Fig. 19. Onion dry weight vs. N concentration in 19931995. 


\section{AGRICULTURAL AND FOOD SCIENCE IN FINLAND}

Vol. 2 (1999): 157-232.

The critical N\% concentration suggested for carrot according to the N_ABLE model (Greenwood et al. 1996a) was in good agreement with the measured data (Fig. 18).

Equations from experimental data produced the following coefficients for carrot:

Model B=1.26 (Greenwood et al. 1996a)

N $0 \mathrm{~kg} \mathrm{ha}^{-1}: \mathrm{B}=1.66$ (1.43-1.90); $\mathrm{n}=36$

$\mathrm{N}$ fertilized : $\mathrm{B}=1.87$ (1.75-1.98); $\mathrm{n}=120$
The critical N\% concentration for onion according to the N_ABLE model (Greenwood et al. 1996a) was clearly higher than the measured concentrations (Fig. 19).

Equations from experimental data produced the following coefficients for onion:

Model $\mathrm{B}=2.42$ (Greenwood et al. 1996a)

N $0 \mathrm{~kg} \mathrm{ha}^{-1}: \mathrm{B}=0.51(0.31-0.70) ; \mathrm{n}=48$

$\mathrm{N}$ fertilized : $\mathrm{B}=1.29(1.20-1.38) ; \mathrm{n}=207$

\section{Discussion}

While this study aimed to find out the effects of $\mathrm{N}$ rate and application method on growth and $\mathrm{N}$ uptake, the results strongly depend on growth conditions creating yield potential. As full yield potential can be realised only if all environmental factors are optimised, environmental factors related to climate, experimental soil, micro-organisms, weeds and pests must be considered (Krug 1997). This background has an effect together with cultivar characteristics, plant density and crop management. When generalising the following results, we must estimate whether it was possible to reach full yield potential and whether the environmental factors corresponded to practical farming conditions.

The experimental soil was rich in nutrients, seemed to mineralise high amounts of $\mathrm{N}$ and retained considerable soil moisture. Soils in practical vegetable production tend to be of this quality, although they are usually more sensitive to drought. Weather conditions varied largely, but in 1993 temperature and rainfall seemed almost optimal for growth. In July 1994, high temperature and probably drought, despite irrigation, stressed growth, which was especially observed with onion. In 1995, high rainfall in May and June delayed crop management measures and establishment, consequently crops never reached the yield levels of previous years.

Cabbage and carrot produced good to moderate yields each year, but the onion yield var- ied greatly. Cabbage and carrot cultivars could, due to their long growing periods, compensate growth quite well after stress periods. On the contrary, onion seemed unable to increase its growth after stress periods. The plant densities used for cabbage and carrot affected growth, but yield was compensated by larger individual plants when the plant density was lower. Crop management succeeded well in general, which can be seen from the ratio of actual to planned plant densities (Table 4) and the marketable yields of onion and carrot.

Concerning criticism of the experimental setup, the use of completely randomized blocks instead of a split-plot design would have enabled us to test all the treatments at the same time. Further, crop rotation could have been considered more carefully. Although residual $\mathrm{N}$ left from the preceding crop was supposed to leach during autumn and spring, and the inorganic $\mathrm{N}$ in soil in spring was low, the experimental setup of the previous year probably increased experimental error. Crop rotation may have partially caused the low onion yield after cabbage in 1995, because residues of cruciferous plants contain allelopathic substances that can decrease growth of the next crop (Oleszek 1987). As fibrous roots were sampled only once or twice in 1993 for determining root length, the dry matter accumulation and $\mathrm{N}$ uptake in the root system is excluded from the discussion. Determination of 


\section{AGRICULTURAL AND FOOD SCIENCE IN FINLAND}

Salo, T. Effects of nitrogen fertilizer on growth of cabbage, carrot and onion

carbon and $\mathrm{N}$ fluxes to the roots must be considered more precisely in forthcoming studies.

\subsection{Inorganic nitrogen in soil}

\section{Amount of inorganic nitrogen in soil}

As can be expected from the good solubility of ammonium nitrate fertilizer (Peterson and Frye 1989), the amount of soil inorganic $\mathrm{N}$ was high one month after fertilizer application. However, the variation in the soil inorganic $\mathrm{N}$ content was considerable. Riley and Guttormsen (1993a) assume that the variation in soil inorganic $\mathrm{N}$ for three weeks after fertilizer application might be caused by incomplete dissolving of fertilizer. They used calcium nitrate, which is also easily soluble in water (Finck 1982). In my experiments a more probable cause of variation is the low number of subsamples and the high differences in inorganic $\mathrm{N}$ content between soil layers.

Although only two to three soil inorganic $\mathrm{N}$ samples were taken during the growing season, the decreasing trend of inorganic $\mathrm{N}$ in soil, caused mainly by crop $\mathrm{N}$ uptake, can be observed. According to the precipitation data, it can be supposed that leaching was low in 1993 and 1994, and that plant $\mathrm{N}$ uptake corresponded to the measured decrease in soil inorganic $\mathrm{N}$ content. Actually, mineralisation of soil $\mathrm{N}$ has often supplied more $\mathrm{N}$ to the plants than the decrease in soil inorganic $\mathrm{N}$ content shows.

While soil inorganic $\mathrm{N}$ at harvest tends to increase with increasing amounts of fertilizer applied (e.g. Everaarts 1993a), the low residual soil inorganic $\mathrm{N}$ contents in my experiments imply that $\mathrm{N}$ rates did not usually exceed crop demand. For example, $\mathrm{N}$ fertilizer rates up to 250 $\mathrm{kg} \mathrm{ha}^{-1}$ did not increase soil inorganic $\mathrm{N}$ content after cabbage in autumn 1993. Soil inorganic N after harvesting carrot was slightly increased when the highest $\mathrm{N}$ rate was used. However, the difference between non-fertilized and $100 \mathrm{~kg} \mathrm{ha}^{-1}$ fertilized treatment was only about $20 \mathrm{~kg} \mathrm{ha}^{-1}$.
This can be explained by the observation of Moussa et al. (1985) that carrot N uptake resulting from soil mineralisation decreased when fertilizer $\mathrm{N}$ rates were increased. However, variation in onion yields, and thus in onion $\mathrm{N}$ uptake, can result in high residual $\mathrm{N}$ in the soil at harvest. The non-fertilized onion plots contained 45 $\mathrm{kg} \mathrm{ha}^{-1}$ inorganic $\mathrm{N}$ in the soil, whereas the broadcast $100 \mathrm{~kg} \mathrm{ha}^{-1}$ plots contained $80 \mathrm{~kg} \mathrm{ha}^{-1}$ in the 0-60 cm layer in 1994. In years such as 1994, when high temperature increases mineralisation of soil $\mathrm{N}$ and onion growth is not good, the recommended $\mathrm{N}$ rates can result in considerable amounts of residual $\mathrm{N}$ in the soil.

\section{Distribution of inorganic nitrogen in soil}

Band placement creates large vertical and horizontal differences in soil inorganic $\mathrm{N}$ content. Although nitrate moves easily in soil, there was more $\mathrm{N}$ close to the fertilizer bands 1-2 months after $\mathrm{N}$ application. Vertical distribution of $\mathrm{N}$ was also definite one month after planting in 1993 and 1994. In the cabbage field, most of the placed $\mathrm{N}$ was in the $10-15 \mathrm{~cm}$ layer and in the $5-10 \mathrm{~cm}$ layer in the onion field. This is in accordance with the field experiment results of Aura (1967), where still in July most of the $\mathrm{N}$ was found at the placement depth and most of the $\mathrm{N}$ was in the fertilizer bands. Everaarts et al. (1996) noticed a clear spatial distribution after band placement even at the time of harvest of cauliflower, if $\mathrm{N}$ rate was high. In my experiments, with all crops most of the broadcast $\mathrm{N}$ was in the top 0 $10 \mathrm{~cm}$ layer, where $\mathrm{N}$ had been incorporated. Nitrogen, broadcast on the soil surface, tends to remain in the top $2.5 \mathrm{~cm}$ for a considerable period without heavy rainfall or a longer wet period (Kaila and Hänninen 1961). When N was broadcast, there was sometimes more $\mathrm{N}$ between plant rows than within rows, as shown also by Everaarts at al. (1996). This indicates that in their experiments the root system was not able to take up $\mathrm{N}$ from interrow areas as the row distance of $75 \mathrm{~cm}$ suggests.

The above mentioned results imply that placed fertilizer $\mathrm{N}$ remains for a considerable 


\section{AGRICULTURAL AND FOOD SCIENCE IN FINLAND}

Vol. 2 (1999): 157-232.

time in the application depth and band. Thus it can take much time for the roots to grow into the $\mathrm{N}$ deposits. If the banded $\mathrm{N}$ dose is high, for example 160-250 $\mathrm{kg} \mathrm{ha}^{-1}$, the osmotic potential in that soil volume is also very low, and thus the roots probably cannot approach the deposits until the $\mathrm{N}$ concentrations are diluted. This was not probably the main reason for the weak start of cabbage growth, since the dry matter production was also low after banding of $60-120 \mathrm{~kg}$ $\mathrm{ha}^{-1} \mathrm{~N}$. One additional problem of steep $\mathrm{N}$ content gradients is that plant roots might concentrate on areas rich in $\mathrm{N}$ and thus have less potential to take up other nutrients and water from other parts of the soil volume. The existence of this phenomenon is, however, unclear as discussed by Robson et al. (1992). On the other hand, if the distance between plants is long and growth period is short, roots probably do not use all the soil volume. In this case, placement of $\mathrm{N}$ in bands close to the plant roots should be beneficial. In addition, the distribution of $\mathrm{N}$ in the $0-10 \mathrm{~cm}$ layer after broadcasting can be problematic in dry conditions where irrigation is not available.

\subsection{Plant growth and final yield}

The highest dry matter accumulations during the experiments were $14000 \mathrm{~kg} \mathrm{ha}^{-1}, 15000 \mathrm{~kg} \mathrm{ha}^{-1}$ and $8000 \mathrm{~kg} \mathrm{ha}^{-1}$ in cabbage, carrot and onion, respectively. Dry matter accumulation of the same magnitude is reported in cabbage e.g. by Welch et al. (1985a) and Guttormsen and Riley (1996), and in carrot e.g. by Greenwood et al. (1980). In European countries, onion is usually cultivated with higher plant density than in Finland and dry matter accumulations of 7000-13 $000 \mathrm{~kg} \mathrm{ha}^{-1}$ (Greenwood et al. 1992) and 15000 $\mathrm{kg} \mathrm{ha}^{-1}$ (Tei et al. 1996) have been reported with $30 \%$ higher plant populations compared to my experiment. Brewster (1990a) reports 10000 to $12000 \mathrm{~kg} \mathrm{ha}^{-1}$ dry weights for spring-sown on- ion in his experiments, but considers $5000 \mathrm{~kg}$ $\mathrm{ha}^{-1}$ dry yield typical of practical farming. The dry matter accumulation of the plants studied usually increases with the plant population, but cabbage and carrot seem to be more effective than onion in compensating low plant density by increasing growth of individual plants.

A sigmoidal (i.e. S-shaped) curve is the basic pattern of limited plant growth (Krug 1997). First dry matter accumulation is low, then increases rapidly and starts to decrease towards the maximum dry weight. This sigmoidal growth curve has been observed e.g. for cabbage by Huett and Dettman (1989), Riley and Guttormsen (1993b) and Guttormsen and Riley (1996), for carrot by Evers (1989) and for onion by Dragland (1975, 1992). The short growing season in Finland can sometimes cause growth cessation early, when the growth rate is still high. This can result in low yield quality due to immature plants. In my experiments all crops were usually harvested when growth still seemed to be high. The reason for the cabbage was the desired head weight, for carrot, a late cultivar that ceased growth due to low temperatures, and for onion due to harvesting directly after leaf falldown.

The growth rate of cabbage remained high until harvest, and was similar to the growth curve of summer cabbage in Norway (Guttormsen and Riley 1996). As in my experiments, Evers (1989) reported that the carrot shoots grew close to their maximum weight in three months, thus following the sigmoidal growth curve. Whereas the storage roots grew slowly during the first two months, growth increased considerably during the third and fourth month. As onion was harvested soon after leaf fall-down, the growth curve also lacked sigmoidal characteristics. Considering allocation between bulb and onion foliage, the bulb dry weight started to increase rapidly at the beginning of July and continued in an exponential fashion, whereas growth of onion foliage was depressed at the end of July. This growth curve of bulb and foliage is similar to the results obtained in Norway by Dragland $(1975,1992)$. The period of rapid foliage growth 


\section{AGRICULTURAL AND FOOD SCIENCE IN FINLAND}

Salo, T. Effects of nitrogen fertilizer on growth of cabbage, carrot and onion

was from the middle of June until the middle of July (Dragland 1975), when the foliage fresh weight was at its maximum. Towards harvest the foliage fresh weight decreased by approximately 50\% (Dragland 1992).

The final yields include more spatial variability than the growth measured by samples. Cabbage yields in my experiment, 50-80 $\mathrm{tha}^{-1}$, were about the same magnitude as the yields reported by e.g. Everaarts (1993a) in the Netherlands and Guttormsen and Riley (1996) in Norway. Although for cabbages the plant density was 35\% lower in 1994 than in 1993, the difference in yield was only $10 \%$. The low yield of $50 \mathrm{t} \mathrm{ha}^{-1}$ in 1995 was due to the aged transplants that also suffered from the moist early summer, resulting in $30 \%$ transplant mortality. The carrot yield levels in my experiments, 45-100 $\mathrm{t} \mathrm{ha}^{-1}$, were usually higher than the yield levels presented by Dragland (1977) in Norway (50-70 t ha-1) and Evers (1989), (39-45 $\mathrm{t} \mathrm{ha}^{-1}$ ) but close to the yields presented by e.g. Roll-Hansen (1976) in Norway and Greenwood et al. (1980) in England. The lowest carrot yield, $45 \mathrm{t} \mathrm{ha}^{-1}$ in 1995 , was caused by a low plant density that was only one fifth of the densities of the previous years. With cabbage and carrot, it seems that the full yield potential can be achieved in quite varying conditions when the plant population is high enough.

Considering onion, plant densities were similar each year but yields varied considerably. The large variation in onion yields, from almost $50 \mathrm{t}$ $\mathrm{ha}^{-1}$ in 1993 to only $20 \mathrm{t} \mathrm{ha}^{-1}$ in 1995 , is typical for Finnish experiments (Aura 1985, Suojala et al. 1998). Yield estimations on the farms have varied between 13 and $22 \mathrm{t} \mathrm{ha}^{-1}$ in 1984-1997 (Information Centre of the Ministry of Agriculture and Forestry 1998). As the vegetative growth and bulb development of onion are strongly dependent on day length and temperature (Brewster 1990a), it is likely that in certain seasons the onion crop is not able to produce high yields in the Finnish climate. However, further studies concerning the effects of photoperiod, temperature and different stresses on onion growth and yield in Finland are required.

\section{Nitrogen rate}

While $\mathrm{N}$ is an essential compound in plant tissues, it especially promotes leaf area index and duration (Marschner 1995). High and long-lasting leaf area increases photosynthesis and dry matter accumulation. The crops studied had variable responses to enhanced $\mathrm{N}$ fertilization. Cabbage benefited from $\mathrm{N}$ application every year, onion two years out of three, but carrot yielded well without $\mathrm{N}$ fertilizer.

The application of a fixed rate of $\mathrm{N}$ before planting seemed to secure good yield levels in years like 1993 and 1994. However, a lower N rate than recommended was sufficient for several crops due to high mineralisation of soil $\mathrm{N}$. While the soil inorganic $\mathrm{N}$ in spring was generally $30-40 \mathrm{~kg} \mathrm{ha}^{-1}$, this alone cannot explain the high plant $\mathrm{N}$ uptakes after small $\mathrm{N}$ rates. Thus the balance sheet method, which estimates soil $\mathrm{N}$ mineralisation during summer, looks a promising method to adjust $\mathrm{N}$ rates. Top dressings can be given according to the balance sheet calculations or more complicated simulation models. The benefit of simulation models can be tested in further studies considering also the year 1995, when part of the fertilizer $\mathrm{N}$ must have been leached.

Growth of cabbage increased every year by $\mathrm{N}$ fertilizer, but in 1994 the low $\mathrm{N}$ rate of $80 \mathrm{~kg}$ $\mathrm{ha}^{-1}$ was sufficient for the highest yield level achieved. Mostly cabbage has been found to respond strongly to fertilizer $\mathrm{N}$ and, for example, $\mathrm{N}_{\text {min }}$ target values for summer cabbage yields of $40000 \mathrm{~kg} \mathrm{ha}^{-1}$ and winter cabbage yields of 80 $000 \mathrm{~kg} \mathrm{ha}^{-1}$ in Germany are 250 and $350 \mathrm{~kg} \mathrm{ha}^{-1}$, respectively (Scharpf and Weier 1996). Nitrogen uptake of this magnitude was also recorded in my experiments. The prevailing $\mathrm{N}$ recommendation for cabbage in Finland, 180-200 kg ha-1 for $50000 \mathrm{~kg} \mathrm{ha}^{-1}$ yield, is rather modest when compared to recommendations of other European countries (Table 1). However, Finnish soils are often high in organic matter and growing seasons with excessive rainfall causing leaching are rare, and thus both soil $\mathrm{N}$ supply and the efficiency of fertilizer $\mathrm{N}$ should be good. 


\section{AGRICULTURAL AND FOOD SCIENCE IN FINLAND}

Vol. 2 (1999): 157-232.

Table 32. $\mathrm{N}$ uptakes and harvested yields of cabbage, carrot and onion cultivated without $\mathrm{N}$ fertilizer.

\begin{tabular}{llcrrl}
\hline Crop & Preceding crop & P and K & $\begin{array}{r}\text { Fresh yield } \\
\mathrm{tha}^{-1}\end{array}$ & $\begin{array}{r}\text { N uptake } \\
\mathrm{kg} \mathrm{ha}^{-1}\end{array}$ & Reference \\
\hline Cabbage & 3 year grass & + & $* 43$ & 117 & Peck (1981) \\
& $?$ & + & 29 & 56 & Welch et al. (1985a) \\
& $?$ (sandy soil) & + & 19 & 33 & Riley and Guttormsen (1993a) \\
& $?$ (loamy soil) & + & 43 & 69 & Riley and Guttormsen (1993a) \\
& Cereals & + & $* 24$ & $* 58$ & Greenwood et al. (1980) \\
& Barley & + & 19 & 70 & Dragland (1982) \\
& Barley & + & 23 & 90 & 1993 , present study \\
& Carrot & + & 51 & 159 & 1994 \\
& Carrot & + & 27 & 117 & 1995 \\
Carrot & Potato & + & $* 64$ & 103 & Dragland (1977) \\
& Cereals & + & 85 & $* 114$ & Greenwood et al. (1980) \\
& Carrot & - & 46 & $* 69$ & Evers (1989) \\
& Barley & + & 71 & 110 & 1993, present study \\
& Onion & + & 97 & 142 & 1994 \\
& Onion & + & 85 & 163 & 1995 \\
Onion & Wheat & + & $34-43$ & $56-66$ & Brown et al. (1988) \\
& $?$ & + & 45 & 65 & Dragland (1992) \\
& Barley & + & $* 45$ & 66 & Henriksen (1984) \\
& Cereals & + & $* 31$ & $* 47$ & Greenwood et al. (1980) \\
& Barley & + & 29 & 48 & 1993, present study \\
& Barley & + & 31 & 81 & 1994 \\
& Cabbage & + & 13 & 26 & 1995 \\
\hline
\end{tabular}

* $\mathrm{N}$ uptake or fresh yield is calculated using other values in the article.

$+=\mathrm{P}$ and $\mathrm{K}$ fertilization

$-=$ no $\mathrm{P}$ and $\mathrm{K}$ fertilization

$?=$ not mentioned in the article

The fact that $\mathrm{N}$ rate had no effect on carrot growth or yield in my experiments is in agreement with several experiments where carrot has produced high yields with a modest $\mathrm{N}$ rate. RollHansen $(1974,1976)$ recommended an $\mathrm{N}$ rate of $78 \mathrm{~kg} \mathrm{ha}^{-1}$ for peat soils and $80 \mathrm{~kg} \mathrm{ha}^{-1}$ for sandy soils in Norway. An N rate of $80 \mathrm{~kg} \mathrm{ha}^{-1}$ was sufficient to produce $55000 \mathrm{~kg} \mathrm{ha}^{-1}$ yields also in Finland (Aura 1985), but $80 \mathrm{~kg} \mathrm{ha}^{-1}$ was the lowest $\mathrm{N}$ rate applied. Dragland (1977) obtained the highest yield after application of $40 \mathrm{~kg} \mathrm{ha}^{-1} \mathrm{~N}$ and the yield then averaged $61000 \mathrm{~kg} \mathrm{ha}^{-1}$. Ekeberg (1986) obtained $43000 \mathrm{~kg} \mathrm{ha}^{-1}$ yield with $\mathrm{N}$ rates of 52 or $104 \mathrm{~kg} \mathrm{ha}^{-1}$. Even in the experiments of Greenwood et al. (1980) where the soil had been cultivated without $\mathrm{N}$ fertilizer for several years to diminish soil $\mathrm{N}$ reserves, the optimum level of $\mathrm{N}$ fertilizer for carrot was $84 \mathrm{~kg}$ $\mathrm{ha}^{-1}$. In Denmark, Sørensen (1993) studied N supply from soil inorganic $\mathrm{N}$ in spring and from $\mathrm{N}$ fertilizers, and recommended $60 \mathrm{~kg} \mathrm{ha}^{-1}$ for this total $\mathrm{N}$ supply when the yield was 85000 $\mathrm{kg} \mathrm{ha}^{-1}$. In Germany, the $\mathrm{N}_{\min }$ value for a carrot yield of $60000 \mathrm{~kg} \mathrm{ha}^{-1}$ is $100 \mathrm{~kg} \mathrm{ha}^{-1}$ (Scharpf and Weier 1996).

In the experiments mentioned above the variation of yield levels from 43000 to $85000 \mathrm{~kg}$ $\mathrm{ha}^{-1}$ with an optimum $\mathrm{N}$ rate is, however, considerable. Moussa et al. (1986) concluded that varied climate, water supply and soil status have a great effect on optimum $\mathrm{N}$ rates. The carrot yield variation in my experiments was mainly due to the weak plant establishment in 1995 . Carrot growth has often been good even without $\mathrm{N}$ fertilizer (Table 32). In the experiments of Ekeberg (1986) and Evers (1989), yields of nonfertilized treatments were as high as $80-95 \%$ of the maximum yields obtained. 


\title{
AGRICULTURAL AND FOOD SCIENCE IN FINLAND
}

\author{
Salo, T. Effects of nitrogen fertilizer on growth of cabbage, carrot and onion
}

Nitrogen promoted onion growth and yield in 1993 and 1995, but in 1994 the non-fertilized plots grew as well as the $\mathrm{N}$ fertilized. This is in accordance with the large variation of optimum $\mathrm{N}$ rates for onion, from 20 to $350 \mathrm{~kg} \mathrm{ha}^{-1}$, as reported by De Visser et al. (1995) from the Netherlands. In Denmark the total N supply from soil and fertilizer that gave the best yield was 135 $\mathrm{kg} \mathrm{ha}^{-1}$ (Sørensen 1996). In Germany, Lang (1988) advised fertilization for onions with 15$20 \mathrm{~kg} \mathrm{ha}^{-1}$ per $10000 \mathrm{~kg} \mathrm{ha}^{-1}$ bulb yield, but there are also higher recommendations such as $160 \mathrm{~kg}$ ha $^{-1}$ for a $60000 \mathrm{~kg} \mathrm{ha}^{-1}$ yield (Scharpf and Weier 1996). All these recommendations and experiments are for sown onion, which benefits from the mineralisation of soil $\mathrm{N}$ during its long growing period. Although onion has a sparse and shallow root system, it can sometimes maintain good yields without $\mathrm{N}$ fertilizers (Table 32). Maximum increases with $\mathrm{N}$ fertilizer have varied from 23 to $90 \%$ (Greenwood et al. 1992).

Nitrogen tends to promote leaf growth while delaying development of reproductive or storage tissues (Marschner 1995). With cabbage, this was not observed. On the contrary, the leaf to head ratio decreased with increasing $\mathrm{N}$ in 1993. The proportion of shoot dry weight to total dry weight for carrot has been slightly higher with higher $\mathrm{N}$ rates (Greenwood et al. 1980), but this was not observed in my experiments. In 1993, high $\mathrm{N}$ rates led to increased onion foliage dry weights towards harvest, but there was not a statistically significant increase in bulb dry weights. The trend that high $\mathrm{N}$ rates led to higher onion foliage growth than bulb growth has been observed by Dragland (1992).

\section{Method of application}

Application methods seemed to affect dry matter accumulation in a more complicated way than expected. The common hypothesis, that band placement results in a better availability of the fertilizer $\mathrm{N}$ and thus a higher yield or lower $\mathrm{N}$ fertilizer demand, was not unambiguously realised. The growth rate of cabbage was lower with band placement than with broadcasting in two years out of three, and the final yield was also lower in one year. On the contrary, the growth rate and final yield of onion was increased in one year out of two, whereas carrot growth was not influenced by the application method. The location of the fertilizer band seems to need careful consideration, as the main reason for higher cabbage growth in broadcast treatments was that $\mathrm{N}$ was easily available to the small transplants. It can be problematic to find common solutions for different crop management techniques. The positive effects of band placement were usually related to low $\mathrm{N}$ rates, thus indicating that band placement may be a more effective application method in low $\mathrm{N}$ supply conditions. This was probably due to weak growth which caused roots to occupy only a small soil volume, and thus part of the $\mathrm{N}$ between rows was unavailable, whereas with good N supply plant yields were usually insensitive to the application method.

Early growth of cabbage benefited from the even distribution of soil inorganic $\mathrm{N}$ created by broadcast fertilization. Later the differences were minimised as the plant roots in placement plots grew into the $\mathrm{N}$ deposits and presumably the plants also created a full-grown root system to utilize water and nutrients from the interrow area. From the root samples it was observed that there were cabbage roots also between rows 63 days after planting in 1993 in both placement and broadcast treatments. This is in accordance with the measurements of Portas (1973), who observed that cabbage roots had developed horizontally about $20 \mathrm{~cm}$ at the start of heading.

Nitrogen placement experiments with cabbage or related species have given positive or no effects. Cauliflower responded well to placement probably due to a shorter growing period than onion and leeks (Sørensen 1996). Everaarts and de Moel (1995 and 1998) got only a few positive effects from band placement and concluded that band placement is not a relevant strategy to increase yields or reduce $\mathrm{N}$ application in cabbage or cauliflower production. Banded $\mathrm{N}$ application did not affect cabbage growth either compared to broadcasting according to Wiedenfeld (1986). Considering placement of all main nutrients, 


\section{AGRICULTURAL AND FOOD SCIENCE IN FINLAND}

Vol. 2 (1999): 157-232.

Smith et al. (1990) found higher yields in cabbage with band placement of NPK fertilizer when NPK fertilizer was placed in double bands $10 \mathrm{~cm}$ on each side of the transplant and $10 \mathrm{~cm}$ deep.

If the immediate nutrient demand of cabbage is supplied by a starter solution, then placement of $\mathrm{N}$ will probably be a more certain method than broadcasting. Nitrogen placement would most likely be beneficial, where irrigation is not possible and in soils where water evaporates rapidly. If the growing period of the cabbage cultivar is short, fertilizer bands can be close to the plant row, but if the growing period of the cultivar is long, fertilizer bands should cover also the interrow area. This enables development of an even root system and prevents formation of high salt concentrations that are especially harmful in dry soil conditions.

The early growth of carrot is slow, and differences in distribution of soil inorganic $\mathrm{N}$ will probably decrease before rapid $\mathrm{N}$ uptake starts. However, Hole and Scaife (1993) stated that the nutrient reserves of carrot seed are used within 15 days or less and then the seedling should be able to take up nutrients from soil solution. At this stage, localized variation in nutrient availability can cause nutrient deficiency. Probably in field conditions there is enough $\mathrm{N}$ in soil solution for seedling uptake of N. In addition, if the growth of the young seedling is restricted, it can be compensated later during the growing season. For these reasons, carrot seems to be insensitive to the placement of $\mathrm{N}$.

Experiments related to nutrient placement with carrots are rare, and data were found only from Norway and Finland. In Norway, placement of NPK fertilizer resulted in 2-12\% higher carrot yields than broadcasting of NPK fertilizer in dry years and had no effect in a rainy year (Ekeberg 1986). As placement of PK fertilizers resulted in a yield increase of the same magnitude as placement of NPK fertilizers, Evers (1989) assumed that the yield increase was mainly due to the placement of phosphorus and potassium.

Onion is reported to be vulnerable to osmotic stress, and even broadcast $\mathrm{N}$ rates between $100-150 \mathrm{~kg} \mathrm{ha}^{-1}$ have decreased early growth by $20 \%$ and the plant population density of onions produced from sets by 15\% (Greenwood et al. 1992). However, in my experiments high soil inorganic $\mathrm{N}$ concentration usually had a positive effect on growth. The only negative trend in growth, although not statistically significant, can be seen in the foliage growth of the placed 100 $\mathrm{kg} \mathrm{ha}^{-1}$ treatment, 57 days after planting in 1993. In addition, root growth was weak at the location of fertilizer band one month after planting in 1993. One reason to suppose that onion could benefit from band placement is that onion roots can occupy only a small soil volume. The depth of rooting did not increase with an increasing total root length throughout the growing period, and the $20 \mathrm{~cm}$ top layer contained $90 \%$ of onion roots (Greenwood et al. 1982). Also Portas (1973) noted that onion had a shallow root system with a depth of $15-21 \mathrm{~cm}$.

The dry matter accumulation of onion was slightly increased by band placement in 1993, and finally there was a clear increase in bulb fresh yield. Placement of $\mathrm{N}$ was clearly beneficial at the two lower $\mathrm{N}$ rates. It seems that placement was a more effective application method in 1993 and it supplied enough $\mathrm{N}$ for good growth even at low application rates. This agrees with the work of Sørensen (1996) where placement of low amounts of $\mathrm{N}$ fertilizer showed higher yield compared to broadcasting of N. The dry matter accumulation followed a similar pattern at the four-leaf stage and 3-4 weeks later. However, bulb yields were not statistically significantly influenced by the method of application (Sørensen 1996). Variation between years can be observed from the study of Wiedenfeld (1986) in Texas, USA, where banding of $\mathrm{N}$ increased onion yield by $12 \%$ in only one year out of three. In 1994, when the soil inorganic $\mathrm{N}$ supply was high even without $\mathrm{N}$ fertilizer, placement of $\mathrm{N}$ did not affect growth. The onion growth rate was low in 1994, probably because of low temperatures in May and high temperatures in July. Thus it seems that placement of $\mathrm{N}$ may be beneficial for onion growth only if the soil $\mathrm{N}$ supply is low and the onion growth rate is high.

Most of the nutrient placement experiments with onion have been made with NP or NPK fer- 


\section{AGRICULTURAL AND FOOD SCIENCE IN FINLAND}

Salo, T. Effects of nitrogen fertilizer on growth of cabbage, carrot and onion

tilizers. Placement of NPK fertilizers has resulted in $12 \%$ (Cooke et al. 1956) or 9\% (Dragland 1992) higher onion yields when compared to broadcasting of NPK fertilizer. Estimating the influence of $\mathrm{N}$ and $\mathrm{P}$ on growth can be done from the experiments of Henriksen (1987) where placement of monoammoniumphosphate to onion sets gave the best yield, placement of superphosphate some yield increase and placement of ammoniumsulphate did not affect yield compared to broadcasting of nutrients. NP placement increased growth by $60 \%$ at the four-leaf stage, by $20 \% 3-4$ weeks later and by only $5 \%$ in yield (Sørensen 1996).

The trend, showing that yield differences equalise towards harvest, has also been noticed in liquid starter fertilizer experiments in England. Rowse et al. (1988) determined 50-60\% higher seedling weights when injecting starter NPK solution below the onion seeds. However, later in the growing season this benefit was lost (Costigan 1988). Injection of starter ammoniumphosphate increased $\mathrm{P}$ and $\mathrm{N}$ concentrations in seedlings and later in the growing season shoot dry weights (Brewster et al. 1991). However, bulb yields were not significantly increased with starter fertilizers. The reason for the disappearance of yield differences was a shortened growing period obtained after using starter fertilizers. Brewster et al. (1991) concluded that starter fertilizer responses frequently result from enhanced $\mathrm{P}$ uptake by seedlings, but enhanced $\mathrm{N}$ uptake may also be important. There are also results where higher yield was obtained with starter fertilizers. Rahn et al. (1996b) measured higher early growth of onions when placing NP starter solution $3 \mathrm{~cm}$ under the drilled onion seed. Dry matter was doubled 10 weeks after drilling and there was still a yield increase of $4.5 \mathrm{t} \mathrm{ha}^{-1}$ until harvest.

\subsection{Nitrogen concentration}

The decrease in $\mathrm{N}$ concentrations during growth was typical for the crops studied (Scaife and
Turner 1983) and for cabbage and carrot corresponded to the equations presented in the N_ABLE model (Greenwood et al. 1996a). The decrease in cabbage $\mathrm{N}$ concentration was similar to the experiments of Riley and Guttormsen (1993a) where cabbage $\mathrm{N}$ concentrations decreased from around mid-June onwards, starting from $45 \mathrm{~g} \mathrm{~kg}^{-1} \mathrm{DM}$ and ending at $10-20 \mathrm{~g}$ $\mathrm{kg}^{-1} \mathrm{DM}$. The decrease in carrot shoot $\mathrm{N}$ concentration in my experiments was about the same magnitude as the decrease from $34 \mathrm{~g} \mathrm{~kg}^{-1} \mathrm{DM}$ (75 das) to $25 \mathrm{~g} \mathrm{~kg}^{-1} \mathrm{DM}$ (116 das) reported by Evers (1989). The N concentration of carrot storage roots has often declined only slightly during the growing period (Nilsson 1987, Evers 1989). This differs from my measurements where storage root $\mathrm{N}$ concentration decreased clearly.

Of the crops studied, only the onion $\mathrm{N}$ concentration was clearly less than in the equation of the N_ABLE model presented by Greenwood et al. (1996a). If the measured $\mathrm{N}$ concentrations are compared to the data presented by Greenwood et al. (1992), they are, however, only slightly lower. There foliage and bulb dry matter of $0.043 \mathrm{t} \mathrm{ha}^{-1}$ contained on average $45 \mathrm{~g} \mathrm{~kg}^{-1}$ $\mathrm{N}$ and dry matter of $10.75 \mathrm{t} \mathrm{ha}^{-1}$ on average $17 \mathrm{~g}$ $\mathrm{kg}^{-1} \mathrm{~N}$. Thus the B value, 4.05, of the critical $\mathrm{N}$ curve given in that study seems to be too high and it has later been lowered for the N_ABLE model to 2.42 (Greenwood et al. 1996a).

The concept of critical $\mathrm{N}$ curve seemed to work well for cabbage and onion where non-fertilized plants had lower plant $\mathrm{N}$ concentrations than fertilized plants. In carrot, growth was good also without $\mathrm{N}$ fertilizer with plant $\mathrm{N}$ concentrations only slightly lower than in the fertilized plants. An approximated critical $\mathrm{N}$ curve can be drawn as a function of dry matter accumulation. Critical $\mathrm{N}$ concentration is considered a valuable tool in fertilization planning (e.g. Peterson and Frye 1989), but nitrate $\mathrm{N}$ analysis is often preferred as being a simpler and faster method (Marschner 1995).

The slight increase in bulb $\mathrm{N}$ concentration towards harvest, observed in my experiments, has also been noticed in Sweden by Nilsson (1980). In his experiments, the $\mathrm{N}$ concentration 


\section{AGRICULTURAL AND FOOD SCIENCE IN FINLAND}

Vol. 2 (1999): 157-232.

of the bulbs increased close to the harvest from $17.5 \mathrm{~g} \mathrm{~kg}^{-1} \mathrm{DM}$ to $23.0 \mathrm{~g} \mathrm{~kg}^{-1} \mathrm{DM}$, the reason being translocation of $\mathrm{N}$ from foliage to bulb.

\section{Nitrogen rate}

A high $\mathrm{N}$ concentration should maintain a more efficient and long established photosynthetic system (Marschner 1995), but when comparing dry matter production to $\mathrm{N}$ concentrations, there were samplings without statistically significant differences in dry matter production although there could be statistically significant differences in $\mathrm{N}$ concentrations. Presumably crops lost their higher yield potential due to the following reasons: cabbage was harvested when the target head size was reached, carrot growth ceased due to low temperatures in late September and onion development depended on climatic factors.

As in my experiments, the concentration of $\mathrm{N}$ in cabbage has been found to increase proportionally with increasing levels of $\mathrm{N}$ applied at planting (Riley and Guttormsen 1993a). Greenwood and Draycott (1989) measured a range of $\mathrm{N}$ in dry matter of harvested summer cabbage from 16 to $40 \mathrm{~g} \mathrm{~kg}^{-1} \mathrm{DM}$ with fertilizer $\mathrm{N}$ levels from 0 to $504 \mathrm{~kg} \mathrm{ha}^{-1}$. Measured ranges of $\mathrm{N}$ in dry matter of harvested winter cabbage were from 22 to $35 \mathrm{~g} \mathrm{~kg}^{-1} \mathrm{DM}$ with $\mathrm{N}$ rates from 0 to $280 \mathrm{~kg} \mathrm{ha}^{-1}$.

Carrot $\mathrm{N}$ concentrations have been found to increase with increasing $\mathrm{N}$ rates (Hansen 1978, Greenwood et al. 1980). In my experiments this effect was seen in storage root $\mathrm{N}$ concentrations in 1993 and 1994, and in shoot $\mathrm{N}$ concentrations in 1994.

Onion $\mathrm{N}$ concentrations were increased with high $\mathrm{N}$ rates, although dry matter accumulation was not increased in 1994. Nitrogen concentration in bulbs at harvest increased with increasing N rates (Dragland 1975, Greenwood et al. 1980). Also in Finnish experiments by Suojala et al. (1998), an increase of $\mathrm{N}$ rate from $50 \mathrm{~kg}$ $\mathrm{ha}^{-1}$ to over $100 \mathrm{~kg} \mathrm{ha}^{-1}$ increased bulb $\mathrm{N}$ concentration by $5 \mathrm{~g} \mathrm{~kg}^{-1} \mathrm{DM}$. With onion there are observations that high $\mathrm{N}$ rates tend to improve foliage growth and to give a dark green colour to the foliage, but often the bulb yield is not higher (Dragland 1992). Luxury consumption of $\mathrm{N}$ should not be especially high in onion. Greenwood et al. (1992) observed that high levels of fertilizer $\mathrm{N}$ did not increase the $\mathrm{N}$ concentration in total plants more than $10 \%$ compared to plants that obtained the lowest rate of fertilizer $\mathrm{N}$ for maximum growth.

\section{Method of application}

Although the shoots of transplanted cabbage are well developed, the roots are limited to a very small soil volume. However, the $\mathrm{N}$ demand of the small cabbage transplant is high and it should be able to get sufficient $\mathrm{N}$ as soon as possible. An onion set, on the contrary, has a large pool of reserves, and thus a high $\mathrm{N}$ demand starts only 1-2 weeks after planting. A carrot seed has reserves for less than 15 days (Hole and Scaife 1993), but as the growth rate of the cultivar studied was slow, $\mathrm{N}$ demand was low at the beginning of the growing period.

If there is not enough $\mathrm{N}$ available to the plants in the soil, their $\mathrm{N}$ concentration will decrease and growth will be retarded. On the other hand, the $\mathrm{N}$ concentration of plants tends to decrease as the dry weight increases (e.g. Greenwood et al. 1996b). Therefore it is difficult to interpret plant $\mathrm{N}$ concentrations, as the $\mathrm{N}$ concentrations can be high because of small plant dry weight. The variation of cabbage $\mathrm{N}$ concentrations in 1994 may be caused by this interaction of plant growth on $\mathrm{N}$ concentrations. At first cabbage $\mathrm{N}$ concentrations were high in broadcast treatments, implying a slightly better soil environment for $\mathrm{N}$ uptake in the broadcast treatments. Then cabbage growth in broadcast treatments increased and $\mathrm{N}$ concentrations were lower until harvest than in the placement treatments.

In the majority of experiments, banding of $\mathrm{N}$ has not affected cabbage leaf $\mathrm{N}$ concentrations compared to broadcasting (Wiedenfeld 1986, Smith et al. 1990). Broadcasting N vs. banding and side dressings did not affect plant $\mathrm{N}$ concentrations either (Peck 1981). In the experi- 


\section{AGRICULTURAL AND FOOD SCIENCE IN FINLAND}

Salo, T. Effects of nitrogen fertilizer on growth of cabbage, carrot and onion

ments of Cutcliffe and Munro (1976), the leaf N concentration of Brussels sprouts was higher with $\mathrm{N}$ placement.

Onion $\mathrm{N}$ concentration responded well to the soil $\mathrm{N}$ availability. When onions were growing in soil with high $\mathrm{N}$ concentration after band placement, the onion $\mathrm{N}$ concentrations were usually higher than in broadcast treatments in 1993. Although onion foliage contained more $\mathrm{N}$ and was more vigorous in placement treatments than in broadcast treatments in 1993, there were only a few positive effects of placement on the dry matter production. The reason for broadcasting resulting in higher plant $\mathrm{N}$ concentrations than placement 55 days after planting in 1994, can be explained by more advanced growth in the placement treatment.

\subsection{Nitrogen uptake}

The $\mathrm{N}$ uptake of the crops studied depended mainly on the dry matter accumulation. Each year the amount of $\mathrm{N}$ uptake was highest with cabbage, moderate and stable with carrot, low and variable with onion. Nitrogen uptake curves were similar to the growth curve in the early and mid-season. Approaching harvest growth still continued, but because there was either a lack of $\mathrm{N}$ in the soil or a decrease in critical plant $\mathrm{N}$ concentration, the $\mathrm{N}$ uptake did not increase as rapidly as the dry weight.

The decrease of the $\mathrm{N}$ uptake rate in the late period of growth agrees with the cabbage experiment of Peck (1981), where the rate of $\mathrm{N}$ uptake was low during the seedling stage, high during midseason and moderate as the plants approached harvest. Many scientists have reported that when cabbage is grown for storage, it is harvested as 'matured' and the $\mathrm{N}$ uptake pattern is sigmoidal (Dragland 1982, Huett and Dettman 1989, Everaarts 1993a). When cabbage is grown for the fresh market with a short growing period, there is continuous uptake until harvest, and sufficient $\mathrm{N}$ must still be available in the soil for optimum growth (Welch et al. 1985a). With carrot, rapid $\mathrm{N}$ uptake started two and a half months after sowing because of storage root $\mathrm{N}$ demand. At that time shoot $\mathrm{N}$ demand started to diminish. The $\mathrm{N}$ uptake curve of onion was similar to the growth curve, and a similar $\mathrm{N}$ uptake curve has also been presented by Dragland (1992).

The amount of $\mathrm{N}$ in the crop residues was $40-50 \%, 30-40 \%$ and $20-30 \%$ of total $N$ uptake in cabbage, carrot and onion, respectively. The amount of $\mathrm{N}$ in the cabbage crop residues has been high, approximately $50 \%$ of total $\mathrm{N}$ uptake, in several experiments (e.g. review by Everaarts 1993a, Peck 1981). The $\mathrm{N}$ content in carrot shoots depends on the cultivar characteristics. In the experiments of Greenwood et al. (1980) the shoots contained $53 \mathrm{~kg} \mathrm{ha}^{-1}$ and storage roots $107 \mathrm{~kg} \mathrm{ha}^{-1} \mathrm{~N}$, but Dragland (1977) determined a higher portion of $\mathrm{N}$ in the shoots, $69 \mathrm{~kg} \mathrm{ha}^{-1}$, whereas storage roots contained $77 \mathrm{~kg} \mathrm{ha}^{-1}$. The percentage of $\mathrm{N}$ in onion crop residues was clearly higher than presented by Suojala et al. (1998) where foliage $\mathrm{N}$ content was less than $7 \%$ of the total $\mathrm{N}$ content. The reason assumed by Suojala et al. (1998) was that the leaves in their experiment were already partly senesced compared to my experiments where the onion foliage was analyzed before senescence. During the senescence there is a translocation of $\mathrm{N}$ from foliage to bulbs and part of the leaves fall to the soil surface.

The $\mathrm{N}$ content in cabbage crop residues after a good yield was considerable, from 134 to 160 $\mathrm{kg} \mathrm{ha}^{-1}$. Nitrogen amounts of this magnitude can have a great effect on leaching but also on supplying $\mathrm{N}$ for subsequent crops, if $\mathrm{N}$ has been retained in the soil by correct management and favourable weather conditions. Strategies for minimizing $\mathrm{N}$ losses and thus retaining most of the $\mathrm{N}$ in crop residues for the next crop are essential. The solutions related to the time of autumn cultivation and catch crops have been studied by e.g. Greenwood et al. (1996b) and Thorup-Kristensen (1994). In Finnish weather conditions, the short growing season creates specific problems for the use of catch crops, and thus research for finding proper solutions is important. 


\section{AGRICULTURAL AND FOOD SCIENCE IN FINLAND}

Vol. 2 (1999): 157-232.

\section{Nitrogen rate}

The crops studied showed clear relationships between $\mathrm{N}$ uptake and either fresh yield or dry matter yield. However, these relationships included considerable variation. Variation was caused either by variable leaf or shoot biomass or variable $\mathrm{N}$ concentrations. Excessive $\mathrm{N}$ uptake creates crop residues rich in $\mathrm{N}$, but this $\mathrm{N}$ is, however, retained to the next season in crop residues more efficiently than in the pool of soil inorganic N.

A cabbage head yield of one ton was achieved by an average $3.8 \mathrm{~kg} \mathrm{~N}$ in the total above-ground crop. This ratio is close or in the range calculated from other experiments (Table 33). When white cabbage has a yield level of 70-90 t ha-1, $\mathrm{N}$ uptake has averaged $390 \mathrm{~kg} \mathrm{ha}^{-1}$, with a range of 300 to $450 \mathrm{~kg} \mathrm{ha}^{-1}$ (Scharpf and Weier 1996). These $\mathrm{N}$ uptake values are similar to the slightly over $300 \mathrm{~kg} \mathrm{ha}^{-1} \mathrm{~N}$ uptakes in my experiments when head yield was more than $70 \mathrm{t} \mathrm{ha}^{-1}$. Variation in the ratio between above-ground crop $\mathrm{N}$ uptake and head yield can be caused by different plant $\mathrm{N}$ concentrations and differences in the leaf growth needed for a certain head yield. In 1993, increasing $\mathrm{N}$ rates from 125 to $250 \mathrm{~kg}$ ha ${ }^{1}$ gave higher $\mathrm{N}$ uptakes, but in 1994 only the non-fertilized treatment took up less $\mathrm{N}$ than the other $\mathrm{N}$ rates. This indicates that in 1994, mineralisation of soil $\mathrm{N}$ produced enough $\mathrm{N}$ for cabbage even with an $\mathrm{N}$ rate of $80 \mathrm{~kg} \mathrm{ha}^{-1}$.

A carrot storage root yield of one ton was achieved by an average $1.6 \mathrm{~kg} \mathrm{~N}$ in the crop. This is in agreement with the results of Greenwood et al. (1980) who measured a total $\mathrm{N}$ uptake of 160 $\mathrm{kg} \mathrm{ha}^{-1}$ with an optimum $\mathrm{N}$ rate and a yield of $100 \mathrm{t} \mathrm{ha}^{-1}$

A bulb yield of one ton was achieved by an average $2.5 \mathrm{~kg} \mathrm{~N}$ in the crop. In other experiments $\mathrm{N}$ uptakes with optimum $\mathrm{N}$ rates have varied from $83-150 \mathrm{~kg} \mathrm{ha}^{-1}$ (Table 34). Onion N uptake was increased with high $\mathrm{N}$ rates and varied in well yielded treatments from 100 to 140 $\mathrm{kg} \mathrm{ha}^{-1}$. Although luxury consumption of $\mathrm{N}$ was low in concentration level, it could result in considerable amounts of $\mathrm{N}$ taken up by the crop.

As cabbage $\mathrm{N}$ demand is high, top dressings
Table 33. N uptakes, head yields and relationships between $\mathrm{N}$ uptakes and head yields of cabbage.

\begin{tabular}{|c|c|c|c|}
\hline $\begin{array}{l}\mathrm{N} \text { uptake } \\
\text { in above } \\
\text { ground crop } \\
\left(\mathrm{kg} \mathrm{ha}^{-1}\right)\end{array}$ & $\begin{array}{l}\text { Head yield } \\
\left(\mathrm{t} \mathrm{ha}^{-1}\right)\end{array}$ & $\begin{array}{c}\text { N uptake / } \\
\text { head yield } \\
\left(\mathrm{kg} \mathrm{t}^{-1}\right)\end{array}$ & Reference \\
\hline 217 & 84 & 2.5 & Peck 1981 \\
\hline 307 & 103 & 3.0 & Peck 1981 \\
\hline 270 & 79 & 3.4 & Dragland 1982 \\
\hline 390 & 115 & 3.4 & Slangen et al. 1990 \\
\hline 136 & 39 & 3.5 & Welch et al. 1985a \\
\hline 330 & 93 & 3.5 & Dragland 1982 \\
\hline 397 & 92 & 4.3 & Slangen et al. 1990 \\
\hline 364 & 65 & 4.7 & Welch et al. 1985a \\
\hline
\end{tabular}

Table 34. N uptakes, bulb yields and relationships between $\mathrm{N}$ uptakes and bulb yields of onion.

\begin{tabular}{cccl}
\hline $\begin{array}{l}\text { N uptake } \\
\text { in bulb } \\
\text { and foliage } \\
\left(\mathrm{kg} \mathrm{ha}^{-1}\right)\end{array}$ & Bulb yield & $\begin{array}{l}\text { N uptake / } \\
\text { bulb yield }\end{array}$ & Reference \\
\hline 83 & 57 & 1.5 & Brown et al. 1988 \\
110 & 73 & 1.5 & Dragland 1992 \\
$104^{*}$ & 61 & $1.7^{*}$ & Henriksen 1987 \\
114 & 63 & 1.8 & Brown et al. 1988 \\
87 & 48 & 1.8 & Suojala et al. 1998 \\
118 & 51 & 2.3 & Suojala et al. 1998 \\
150 & 60 & 2.5 & Dragland 1992 \\
\hline
\end{tabular}

* solely in bulbs

should be used as safety measure against leaching of $\mathrm{N}$ caused by high rainfall after planting. Top dressings should maintain a sufficient soil inorganic $\mathrm{N}$ content from one month after planting until harvest. As the leaves of cabbage cover the soil surface almost totally towards harvest, the last top dressing must usually be given more than one month before harvest. The current recommendation for applying top dressings in two portions (Soil Testing Laboratory of Finland 1997) seems reasonable as the useful time period for applications lasts from one month to three months after planting. If natural rainfall is low, irrigation must be used to transport fertilizer $\mathrm{N}$ to the root zone. As the $\mathrm{N}$ demand of carrot is 


\section{AGRICULTURAL AND FOOD SCIENCE IN FINLAND}

Salo, T. Effects of nitrogen fertilizer on growth of cabbage, carrot and onion

very low at first, in soils susceptible to leaching a major portion of the $\mathrm{N}$ fertilizer should be applied as top dressing. Top dressings for onion should maintain a sufficient soil inorganic $\mathrm{N}$ content from 30 to 80 days after planting. As onion $\mathrm{N}$ demand is rather low, and growth does not necessarily increase although $\mathrm{N}$ uptake increases, one top dressing should be sufficient.

When $\mathrm{N}$ supply was low, i.e. in the non-fertilized treatments, cabbage and carrot were able to take up large amounts of N. This indicates a high $\mathrm{N}$ mineralisation potential in the experimental soils because the content of inorganic $\mathrm{N}$ in the soil was low in each spring. Especially in 1994, high temperatures in July increased N mineralisation, and the total $\mathrm{N}$ uptake of cabbage without $\mathrm{N}$ fertilizer was as high as $159 \mathrm{~kg} \mathrm{ha}^{-1}$. Experiments with Brussels sprouts and cauliflower indicate that Brassica vegetables can have well developed root systems (Everaarts 1993a). A cabbage crop seems to take up 60-70 $\mathrm{kg} \mathrm{ha}^{-1}$ of $\mathrm{N}$ from non-fertilized plots (Table 32). Nitrogen uptake of this magnitude usually gives only low yields, but it gives an estimate of the ability of cabbage to use soil $\mathrm{N}$ reserves. In the present experiments the $\mathrm{N}$ uptake of carrot without $\mathrm{N}$ fertilizer was close to $150 \mathrm{~kg} \mathrm{ha}^{-1}$ each year. As carrot often produces a good yield even without $\mathrm{N}$ fertilization (Table 32), it is able to take up considerable amounts of mineralised soil $\mathrm{N}$.

Although onion roots occupy a small soil volume, they are able to take up slightly over 50 $\mathrm{kg} \mathrm{ha}^{-1} \mathrm{~N}$ during the growing season from soils with low $\mathrm{N}$ supply. Nitrogen uptake without $\mathrm{N}$ fertilizer in 1993 was typical compared to other studies (Table 32). In 1994, N uptake without $\mathrm{N}$ fertilizer was clearly higher than in 1993 and corresponded to the $\mathrm{N}$ uptakes of high yield levels. This can be explained by good conditions for soil $\mathrm{N}$ mineralisation as the top soil was kept at optimum moisture and the temperature was high in July 1994.

\section{Method of application}

Plant $\mathrm{N}$ uptake is a better estimator of $\mathrm{N}$ availability from different $\mathrm{N}$ application methods than plant $\mathrm{N}$ concentration. When the availability of $\mathrm{N}$ in the soil is good, we should have a high dry matter accumulation and high $\mathrm{N}$ concentration to establish optimum growth. In this experiment, the application methods did not usually affect $\mathrm{N}$ uptake at harvest, but differences were observed during the growing period.

At the beginning of two years out of three, there was a higher cabbage $\mathrm{N}$ uptake in broadcast than in placement treatments. This implies better soil $\mathrm{N}$ availability from broadcast than from placement treatments for the small transplants. Towards harvest the differences were equalised, and thus $\mathrm{N}$ can be considered to have been equally available to full-grown plants regardless of the application method. This conclusion is supported by the results of Everaarts et al. (1996) where band placement did not differ from broadcasting in the effect on $\mathrm{N}$ uptake of cauliflower.

At least two possible reasons for the effectiveness of carrot in utilizing soil $\mathrm{N}$ reserves can be mentioned. Firstly, rapid uptake begins just two and a half months after sowing and thus soil $\mathrm{N}$ mineralisation can supply a large proportion of the carrot $\mathrm{N}$ demand. Secondly, the carrot root system is dense and able to grow in deep soil horizons (Pietola 1995). According to Pietola (1995) the large root system of carrot consisting mostly of fine roots in the fertile soil horizon may be the reason for the insensitivity of carrot yield to water and nitrogen in many studies.

Onion N uptake was increased when fertilizer was placed in 1993, but not in 1994 when soil $\mathrm{N}$ mineralisation was high. Thus placement of $\mathrm{N}$ can increase $\mathrm{N}$ uptake when the soil $\mathrm{N}$ supply is low and growth is fast.

\subsection{Apparent recovery of fertilizer nitrogen}

Apparent recovery was not the especially good indicator of the use of fertilizer N. Experimental fields mineralised plenty of organic $\mathrm{N}$ for the 


\section{AGRICULTURAL AND FOOD SCIENCE IN FINLAND}

Vol. 2 (1999): 157-232.

crop $\mathrm{N}$ uptake and thus small doses of fertilizer $\mathrm{N}$ increased crop $\mathrm{N}$ uptake more than the actual $\mathrm{N}$ dose. Furthermore, carrot took up as much $\mathrm{N}$ from non-fertilized as from fertilized plots. High $\mathrm{N}$ rates decreased the apparent recovery only for onion in 1993. Considering application methods, placement of $\mathrm{N}$ increased the apparent recovery for onion in 1993.

Cabbage has a rather high variation in apparent recovery of $\mathrm{N}$, as shown in the data collected by Everaarts (1993a) where the apparent recovery of $\mathrm{N}$ with cabbage varied from 0.37 to 1.24. If there are high amounts of available soil $\mathrm{N}$, the apparent recovery of $\mathrm{N}$ can easily exceed 1.00, as was the case in my experiments in 1994. The apparent recoveries of $\mathrm{N}$ in 1993 were in the range $0.79-0.85$ that is typical for summer cabbage in England (Greenwood et al. 1989, Greenwood and Draycott 1989). Apparent recovery of $\mathrm{N}$ with cabbage seems to decrease with increasing fertilizer rate (Greenwood et al. 1989, Riley and Guttormsen 1993a). Apparent recoveries of $\mathrm{N}$ varied from an average 0.13 to 0.72 between two fields, two varieties, seven $\mathrm{N}$ fertilizer rates and two years (Riley and Guttormsen 1993a). Apparent recoveries of $\mathrm{N}$ with summer cabbage were somewhat higher than the apparent recoveries of $\mathrm{N}$ with winter cabbage, probably as a result of the more rapid initial growth and $\mathrm{N}$ uptake of the former crop (Riley and Guttormsen 1993a). In the dry years of 1993 and 1994 in Norway, apparent recovery of $\mathrm{N}$ was approximately 0.80 and high rates of $\mathrm{N}$ application did not substantially decrease $\mathrm{N}$ recovery (Guttormsen and Riley 1996).

The maximum apparent recovery of $\mathrm{N}$ for carrot measured by Greenwood et al. (1989) was 0.69 . In their experiments the soil had been cultivated without $\mathrm{N}$ fertilizer several years to diminish soil N reserves (Greenwood et al. 1980), and thus application of fertilizer $\mathrm{N}$ could not increase the utilisation of soil N. In my experiments the mineralisation of soil $\mathrm{N}$ was so high that fertilizer $\mathrm{N}$ was not required at all.

Greenwood et al. (1992) presented a linear equation for the decline of apparent recovery of $\mathrm{N}$ when increasing $\mathrm{N}$ rates with onion:

Apparent recovery of fertilizer $\mathrm{N}=$ $0.50-0.00086 \times($ fertilizer $\mathrm{N})$

Earlier Greenwood et al. (1989) had presented the apparent recovery of an infinitely small amount of $\mathrm{N}$ to be 0.31 for onion. In my experiments there was also a linear decline in the apparent recovery of $\mathrm{N}$ in 1993 with higher $\mathrm{N}$ rates. However, in 1994 the apparent recovery of $\mathrm{N}$ was high, from 0.85 to 1.40 , and was not affected by the $\mathrm{N}$ rate. This can be caused by high mineralisation of soil organic N. When there is soil inorganic $\mathrm{N}$ from sources other than $\mathrm{N}$ fertilizer, small amounts of fertilizer $\mathrm{N}$ can improve root growth and $\mathrm{N}$ uptake, thus producing apparent recovery values above 1.0. High apparent recovery of $\mathrm{N}$ for onion, from 1.0 to 1.8 , was also reported by Sørensen (1996). It seems that the apparent recovery of $\mathrm{N}$ can be higher for onion than suggested by Greenwood et al. (1992).

Apparent recovery of $\mathrm{N}$ was higher with placed fertilizer for onion in 1993, because onion growth benefited from the good availability of fertilizer N. For onion in 1994, the method of application did not affect the apparent recovery of $\mathrm{N}$, which was also the case in the experiments of Sørensen (1996). Apparent recoveries of $\mathrm{N}$ in his experiments were high suggesting high mineralisation of soil organic $\mathrm{N}$, and thus conditions were similar to 1994 in my experiments. However, it seems that placement can improve the $\mathrm{N}$ uptake efficiency of onion in conditions where availability of soil inorganic $\mathrm{N}$ is low. 


\section{AGRICULTURAL AND FOOD SCIENCE IN FINLAND}

Salo, T. Effects of nitrogen fertilizer on growth of cabbage, carrot and onion

\section{Conclusions}

One $\mathrm{t} \mathrm{ha}^{-1}$ of fresh yield required approximately $3.8 \mathrm{~kg}, 1.6 \mathrm{~kg}$ and $2.5 \mathrm{~kg} \mathrm{~N}$ in cabbage, carrot and onion crops including residues, respectively. Yields of $80 \mathrm{t} \mathrm{ha}^{-1}$ for cabbage, $90 \mathrm{t} \mathrm{ha}^{-1}$ for carrot and 35-40 $\mathrm{t} \mathrm{ha}^{-1}$ for onion were obtained when the total crop $\mathrm{N}$ uptake was $300 \mathrm{~kg} \mathrm{ha}^{-1}$, $150 \mathrm{~kg} \mathrm{ha}^{-1}$ and $120 \mathrm{~kg} \mathrm{ha}^{-1}$, respectively. The variation in yield and $\mathrm{N}$ uptake was highest with onion, whereas the yield and $\mathrm{N}$ uptake of cabbage and carrot were fairly uniform each year. In cabbage almost $50 \%$ of total $\mathrm{N}$ was in crop residues, whereas in carrot $35 \%$ and in onion about $25 \%$ of the total $\mathrm{N}$ was in crop residues. When the results obtained in these experiments are compared to the $\mathrm{N}$ fertilizer recommendations applied in Finland, it can be concluded that the recommendations correspond to the actual $\mathrm{N}$ demand. However, while carrot was very efficient in utilising soil $\mathrm{N}$ reserves, it is probable that the $\mathrm{N}$ recommendation for carrot could be lowered.

The $\mathrm{N}$ uptake from non-fertilized soil varied from 29 to $160 \mathrm{~kg} \mathrm{ha}^{-1}$, depending on the growing season and the crop. Cabbage and carrot utilised soil $\mathrm{N}$ efficiently, usually taking up more than $100 \mathrm{~kg} \mathrm{ha}^{-1}$ per year from non-fertilized soil. Onion, on the contrary, made relatively poor use of soil $\mathrm{N}$, usually less than $50 \mathrm{~kg} \mathrm{ha}^{-1}$ per year from non-fertilized soil.

The plant $\mathrm{N}$ concentration decreased with dry matter accumulation. With cabbage and onion, a difference in $\mathrm{N}$ concentration between fertilized and non-fertilized plants was established. As carrot grew equally well with and without $\mathrm{N}$ fertilizer, the plant $\mathrm{N}$ concentrations differed only slightly. However, it is possible to suggest critical plant $\mathrm{N}$ concentrations for all crops as a function of dry matter accumulation.

With all crops the rate of $\mathrm{N}$ uptake was low in early summer. After one month, $\mathrm{N}$ uptake in- creased in cabbage and onion. This uptake continued until harvest, i.e. mid-August for onion and early September for cabbage. Nitrogen uptake by carrot started rapidly just two months after sowing, but continued until harvest at the end of September. According to these periods of high $\mathrm{N}$ uptake, top dressings for cabbage and onion should be applied one month after planting, and for carrot two months after sowing. As the $\mathrm{N}$ demand of cabbage is high, another top dressing can be applied two months after planting.

After harvest the soil mineral $\mathrm{N}$ content was generally low, i.e. below $25 \mathrm{~kg} \mathrm{ha}^{-1}$ at a depth of 0-60 cm. Onion was an exception with poor growth in 1994, when soil mineral $\mathrm{N}$ after the highest $\mathrm{N}$ rate was $80 \mathrm{~kg} \mathrm{ha}^{-1}$ at a depth of $0-60$ $\mathrm{cm}$ after harvest. The apparent recovery of fertilizer $\mathrm{N}$ was generally good in all crops. The fertilizer rates were low enough to prevent a decrease in apparent recovery values.

The vegetables differed widely in their $\mathrm{N}$ requirement, and thus in their potential to cause losses of $\mathrm{N}$. The $\mathrm{N}$ requirement of cabbage especially was high and the crop residues contained large amounts of $\mathrm{N}$. Thus cabbage requires careful management to keep $\mathrm{N}$ losses low.

Band placement of $\mathrm{N}$ compared to broadcasting of $\mathrm{N}$ did not usually affect dry matter accumulation. Only onion in 1993 grew slightly better and cabbage in 1993 and 1994 slightly worse after band placement. However, we can assume that if plant roots are not able to take up $\mathrm{N}$ from the interrow area or if the moisture content of the top soil will be low, band placement of $\mathrm{N}$ will be more efficient than broadcasting of $\mathrm{N}$. The apparent recovery of fertilizer $\mathrm{N}$ was increased in onion 1993, when growth was good and the soil $\mathrm{N}$ supply was only moderate. 


\section{AGRICULTURAL AND FOOD SCIENCE IN FINLAND}

Vol. 2 (1999): 157-232.

\section{References}

Aaltonen, V.T., Aarnio, B., Hyyppä, E., Kaitera, P., Keso, L., Kivinen, E., Kokkonen, P., Kotilainen, M.J., Sauramo, M., Tuorila, P. \& Vuorinen, J. 1949. A critical review of soil terminology and soil classification in Finland in the year 1949. Journal of the Scientific Agricultural Society of Finland 21: 37-66.

Association of Rural Advisory Centres 1987a. Porkkanan tuotanto. Maatalouskeskusten liitto. Tieto tuottamaan 46. Helsinki. 104 p. (in Finnish).

- 1987b. Keräkaalin tuotanto. Maatalouskeskusten liitto. Tieto tuottamaan 47. Helsinki. 87 p. (in Finnish).

Aura, E. 1967. Effect of the placement of fertilizer on the development of spring wheat. Journal of the Scientific Agricultural Society of Finland 39: 148-155.

- 1985. Avomaan vihannesten veden ja typen tarve. (Abstract: Nitrogen and water requirements for carrot, beetroot, onion and cabbage). Maatalouden tutkimuskeskus. Tiedote 7/85. (Communications of the Agricultural Research Centre of Finland). 61 p.

Below, F.E. 1994. Nitrogen metabolism and crop productivity. In: Pessarakli, M. (ed.). Handbook of Plant and Crop Physiology. Marcel Dekker, Inc. New York, USA. p. 275-301.

Blake, G.R. \& Hartge, K.H. 1986. Bulk density. In: Klute, A. (ed.). Methods of Soil Analysis. Madison, Wisconsin, American Society of Agronomy. Agronomy 9, 1: 363-376.

Böhm, W. 1979. Methods of Studying Root Systems. Springer-Verlag. Berlin. $188 \mathrm{p}$.

Brewster, J.L. 1990a. Physiology of crop growth and bulbing. In: Rabinowitch, H.D. \& Brewster, J.L. (eds.). Onions and Allied Crops. Vol. I. CRC Press, Boca Raton. p. 54-81.

- 1990b. Cultural systems and agronomic practices in temperate climates. In: Rabinowitch, H.D. \& Brewster, J.L. (eds.). Onions and Allied Crops. Vol. II. CRC Press, Boca Raton. p. 2-30.

-, Rowse, H.R. \& Bosch, A.D. 1991. The effects of subseed placement of liquid $N$ and $P$ fertilizer on the growth and development of bulb onions over a range of plant densities using primed and non-primed seed. Journal of Horticultural Science 66: 551-557.

Brown, B.D., Hornbacher, A.J. \& Naylor, D.V. 1988. Sulfur-coated urea as a slow-release nitrogen source for onions. Journal of American Society of Horticultural Science 113: 864-869.

Bundesgemüsebauverband Österreichs 1995. Richtlinien für die Integrierte Produktion von Gemüse in Österreich. Gemüse spezial 3A/1995: 1-33.

Cooke, G.W., Jackson, M.V., Widdowson, F.V. \& Wilcox, J.C. 1956. Fertilizer placement for horticultural crops. Journal of Agricultural Science 47: 249-255.

Costigan, P. 1988. The placement of starter fertilisers to improve the early growth of drilled and transplanted vegetables. Proceedings of the Fertiliser Society 274: $1-24$.

Cutcliffe, J.A. \& Munro, D.C. 1976. Effects of method and rate of application of nitrogen on yield and leaf tis- sue composition of Brussels sprouts. Canadian Journal of Plant Science 56: 543-548.

Danielson, R.E. \& Sutherland, P.L. 1986. Porosity. In: Klute, A. (ed.). Methods of Soil Analysis. Madison, Wisconsin, American Society of Agronomy. Agronomy 9, 1: 443-462.

De Visser, C.L.M., van den Berg, W. \& Niers, H. 1995 Relation between soil mineral nitrogen before sowing and optimum nitrogen fertilization in onions. Netherlands Journal of Agricultural Science 43: 333-345.

Dragland, S. 1975. Nitrogen- og vassbehov av kepaløk. (Abstract: Nitrogen and water requirements in onions). Forskning og Forsøk i Lantbruket 26: 93-113.

- 1977. Nitrogen- og vassbehov hos gulrot. (Abstract: Nitrogen and water requirements for carrots). Forskning og Forsøk i Landbruket 29: 139-159.

- 1982. Nitrogenfordeling til sein kvitkål. (Abstract:Timing of $\mathrm{N}$-application to late cabbage). Forskning og Forsøk i Landbruket 33: 27-35.

- 1992. Nitrogen og dyppgjødsling til kepaløk. Faginfo 12: $14-26$.

Ekeberg, E. 1986. Radgjødsling på myr. (Abstract: Fertilizer placement on peat soils). Forskning og Forsøk i Landbruket 37: 23-28.

Elonen, P. 1971. Particle-size analysis of soil. Acta Agralia Fennica 122: 1-122.

Engblom, S. 1993. Avomaan vihanneskasvitaulukko. In: Kaukovirta, E. et al. (eds.) Puutarhakalenteri 1993. Puutarhaliitto. Helsinki. p. 28-29. (in Finnish).

Esala, M. 1995. Changes in the extractable ammoniumand nitrate-nitrogen contents of soil samples during freezing and thawing. Communications in Soil Science and Plant Analysis 26: 61-68.

- \& Larpes, G. 1986. Effect of placement technique and amount of fertilizer on spring wheat and barley grown on clay soils. I. Effect on grain yield. Annales Agriculturae Fenniae 25: 159-167.

Everaarts, A.P. 1993a. General and quantitative aspects of nitrogen fertilizer use in the cultivation of Brassica vegetables. Acta Horticulturae 339: 149-160.

- 1993b. Strategies to improve the efficiency of nitrogen fertilizer use in the cultivation of Brassica vegetables. Acta Horticulturae 339: 161-173.

- \& de Moel, C.P. 1995. The effect of nitrogen and the method of application on the yield of cauliflower. Netherlands Journal of Agricultural Science 43: 409-418.

- \& de Moel, C.P. 1998. The effect of nitrogen and the method of application on yield and quality of white cabbage. European Journal of Agronomy 9: 203-211.

-, de Moel, C.P. \& Van Noordwijk, M. 1996. The effect of nitrogen and the method of application on nitrogen uptake of cauliflower and on nitrogen in crop residues and soil at harvest. Netherlands Journal of $\mathrm{Ag}$ ricultural Science 44: 43-55.

Evers, A.-M. 1989. The role of fertilization practices in the yield and quality of carrot (Daucus carota L.). Journal of Agricultural Science in Finland 61: 323360. 


\section{AGRICULTURAL AND FOOD SCIENCE IN FINLAND}

Salo, T. Effects of nitrogen fertilizer on growth of cabbage, carrot and onion

Feller, C., Bleiholder, H., Buhr, L., Hack, H., Hess, M., Klose, R., Meier, U., Stauss, R., van den Boom, T. \& Weber, E. 1995. Phänologische Entwicklungsstadien von Gemüsepflanzen. I. Zwiebel-, Wurzel-, Knollen- und Blattgemüse. Nachrichtenblatt des Deutschen Pflanzenschutzdienstes 47: 193-206.

Finck, A. 1982. Fertilizers and Fertilization. Indtroduction and Practical Guide to Crop Fertilization. Verlag Chemie. Weinheim. $438 \mathrm{p}$.

Fink, M. \& Scharpf, H.-C. 1993. N-Expert - A decision support system for vegetable fertilisation in the field. Acta Horticulturae 339: 67-74.

Fitzpatrick, E.A. 1980. Soils. Their Formation, Classification and Distribution. 1st ed. The Pitman Press, Bath. 353 p.

Freund, R.J. \& Littell, R.C. 1991. SAS System for Regression. 2nd ed. SAS Institute Inc. Cary, NC. USA. $210 \mathrm{p}$.

Greenberg, A., Connors, J. \& Jenkins, D. 1980. Nitrogen (Nitrate). In: American Public Health Association. Standard Methods for the Examination of Water and Wastewater. 15th ed. Washington. p. 391-404.

Greenwood, D.J., Cleaver, T.J., Turner, M.K., Hunt, J., Niendorf, K.B. \& Loquens, M.H. 1980. Comparison of the effects of nitrogen content and quality of 21 different vegetable and agricultural crops. Journal of Agricultural Science, Cambridge 95: 471-485.

- \& Draycott, A. 1989. Experimental validation of an $\mathrm{N}$-response model for widely different crops. Fertilizer Research 18: 153-174.

-, Gerwitz, A., Stone, D.A. \& Barnes A. 1982. Root development of vegetable crops. Plant and Soil 68: 7596.

-, Kubo, K., Burns, I.G. \& Draycott, A. 1989. Apparent recovery of fertilizer $\mathrm{N}$ by vegetable crops. Soil Science and Plant Nutrition 35: 367-381.

-, Neeteson, J.J., Draycott, A. \& Stone, D.A. 1992. Measurement and simulation of the effects of $\mathrm{N}$-fertilizer on growth, plant composition and distribution of soil mineral- $\mathrm{N}$ in nationwide onion experiments. Fertilizer Research 31: 305-318.

-, Rahn, C.R. \& Draycott, A. 1996a. Modelling nitrogen fertiliser requirements of field grown crops. $N A B L E$ Nitrogen response model for research. (Version Jan. 1996). Horticultural Research International. Wellesbourne. Warwick. 22 p.

-, Rahn, C., Draycott, A., Vaidyanathan, L.V. \& Paterson, C. 1996b. Modelling and measurement of the effects of fertilizer- $\mathrm{N}$ and crop residue incorporation on $\mathrm{N}$-dynamics in vegetable cropping. Soil Use and Management 12: 13-24.

Guttormsen, G. \& Riley, H. 1996. Testing a nitrogen advisory model for vegetables. Acta Horticulturae 428: 205-214.

Hansen, H. 1978. The influence of nitrogen fertilization on the chemical composition of vegetables. Qualitas Plantarum -Plant Foods for Human Nutrition XXVIII: 45-63.

Henriksen, K. 1984. Kvælstofgødskning af såløg (Allium cepa) ved god vandforsyning. (Abstract: Nitrogen fertilizing in seed onions (A. cepa) at high soil moisture content.) Tidskrift for Planteavl 88: 621-631.
- $\quad$ 1987. Effect of $\mathrm{N}$ - and P-fertilization on yield and harvest time in bulb onions (Allium cepa L.) Acta Horticultarae 43: 207-215.

Hole, C.C. \& Scaife, A. 1993. An analysis of the growth response of carrot seedlings to deficiency in some mineral nutrients. Plant and Soil 150: 147-156.

Huett, D.O. \& Dettman, E.B. 1989. Effect of nitrogen on growth quality and nutrient uptake of cabbages grown in sand culture. Australian Journal of Experimental Agriculture 29: 875-881.

Information Centre of the Ministry of Agriculture and Forestry 1998. Puutarhayritysrekisteri 1997. Helsinki. 108 p. (in Finnish and in Swedish).

Juusela, T. \& Wäre, M. 1956. Suomen peltojen kuivatustila. Draining condition of the cultivated fields in Finland. Soil and Hydrotechnical Researches 8: 189.

Kaila, A. \& Hänninen, P. 1961. Fertilizer nitrogen in soil. Journal of the Scientific Agricultural Society of Finland 33: 167-184.

Klute, A. 1986. Water retention: Laboratory methods. In: Klute, A. (ed.). Methods of Soil Analysis. Madison, Wisconsin, American Society of Agronomy. Agronomy 9, 1: 635-662.

Krom, M.D. 1980. Spectrophotometric determination of ammonia: A study of a modified Berthelot reaction using salicylate and dichloroisocyanurate. Analyst 105: 305-316

Krug, H. 1997. Environmental influences on development, growth and yield. In: Wien, H.C. (ed.). The Physiology of Vegetable Crops. CAB. University Press. Cambridge. p. 101-180

Kurki, M. 1974. Viljavuustutkimuksen hyväksikäyttö puutarhaviljelyssä. Viljavuuspalvelu Oy. Helsinki. 8 p. (in Finnish).

-, Lakanen, E., Mäkitie, O. \& Sillanpää, M. 1965. Viljavuusanalyysien ilmoitustapa ja tulkinta. Summary: Interpretation of soil testing results. Annales Agriculturae Fenniae 4: 145-153.

Lang, C. 1988. Gezielte N-versorgnung der Sommerzwiebel. Gemüse 24: 140-144.

Langer, R.H.M. \& Hill, G.D. 1991. Agricultural Plants. 2nd ed. Cambridge University Press, UK. 387 p.

Larsson, L., Ferm, M., Kasimir-Klemedtsson, Å. \& Klemedtsson, L. 1998. Ammonia and nitrous oxide emissions from grass and alfalfa mulches. Nutrient Cycling in Agroecosystems 51: 41-46.

Lehtinen, S. 1984. Avomaan vihannesten lannoitus- ja kastelukokeet. Maatalouden tutkimuskeskus. Tiedote 21/84. (Communications of the Agricultural Research Centre of Finland). 62 p. (in Finnish).

Littell, R.C., Milliken, G.A., Stroup, W.W. \& Wolfinger, R.D. 1996. SAS System for Mixed Models. SAS Institute Inc. Cary, NC. USA. 633 p.

MAFF 1994. Fertiliser Recommendations for Agricultural and Horticultural Crops. Ministry of Agriculture, Fisheries and Food, Reference Book 209. HMSO, London, England. 6th ed. $112 \mathrm{p}$.

Markkula, I. (ed.) 1993. Ajankohtaisia kasvinsuojeluohjeita. Plant Protection Organisation. Jokioinen. $168 \mathrm{p}$ (in Finnish).

Marschner, H. 1995. Mineral Nutrition of Higher Plants. 


\section{AGRICULTURAL AND FOOD SCIENCE IN FINLAND}

Vol. 2 (1999): 157-232.

2nd ed. Academic Press, Cambridge. 889 p.

Mattsson, M., Husted S. \& Schjoerring J.K. 1998. Influence of nitrogen nutrition and metabolism on ammonia volatilization in plants. Nutrient Cycling in Agroecosystems 51: 35-40.

Michigan State University 1989. User's guide to MSTATC. A Software Program for the Design, Management and Analysis of Agronomic Research Experiments. Michigan State University. 408 p.

Moussa, A.G., Markgraf, G. \& Geissler, T. 1985. Untersuchungen über die Ausnutzung von Dünger- und Bodenstickstoff durch Speisemöhren. Archive für Gartenbau 33: 59-66.

-, Markgraf, G. \& Geissler, T. 1986. Ertrag, Qualität und Nitratgehalt von Speisemöhre und Spinat bei steigender Stickstoffdüngung im Modellversuch. Archive für Gartenbau 34: 45-54.

Neeteson, J. 1995. Nitrogen management for intensively grown arable crops and field vegetables. In: Bacon, P.E. (ed.). Nitrogen Fertilization in the Environment. Marcel Dekker Inc. New York. p. 295-325.

NIAB 1997. NIAB Vegetable Variety Handbook. National Institute of Agricultural Botany. Cambridge, UK. $114 \mathrm{p}$.

Nilsson, T. 1980. The influence of the time of harvest on the chemical composition of onions. Swedish Journal of Agricultural Research 10: 77-88.

- 1987. Growth and chemical composition of carrots as influenced by the time of sowing and harvest. Journal of Agricultural Science 108: 459-468.

Nordic Council of Ministers 1992. Leaching and runoff of nitrogen from agricultural areas in the Nordic countries. Nordiske Seminar- og Arbejdsrapporter 1992:594. 68 p.

Oleszek, W. 1987. Allelopathic effects of volatiles from some Cruciferae species on lettuce, barnyard grass and wheat growth. Plant and Soil 102: 271-273.

Orion 1983. Guide to ion analysis. Massachusetts. $45 \mathrm{p}$

Peck, N.H. 1981. Cabbage responses to $\mathrm{N}$ fertilization. Agronomy Journal 73: 679-684.

Pessala, R. 1993. Avomaaviljelyyn suositeltavat vihanneslajikkeet. In: Kaukovirta, E. et al. (eds.) Puutarhakalenteri 1993. Puutarhaliitto. Helsinki. p. 20-24. (in Finnish).

Peterson, G.A. \& Frye, W.W. 1989. Fertilizer nitrogen management. In: Follett, R.F. (ed.). Nitrogen Man agement and Ground Water Production. Developments in agricultural and managed forest ecology 21. Elsevier. New York. p. 183-219.

Pietola, L. 1995. Effect of soil compactness on the growth and quality of carrot. Agricultural Science in Finland 4: 139-237.

Portas, C.A.M. 1973. Development of root systems during the growth of some vegetable crops. Plant and Soil 39: 507-518.

Rahn, C., Greenwood. D.J. \& Draycott, A. 1996a. Prediction of nitrogen fertilizer requirement with the HR WELL-N computer model. In: van Cleemput, O. et al. (eds.). Progress in Nitrogen Cycling Studies. Kluwer. Dordrecth. p. 255-258.

-, Shephard, M.A. \& Hiron, R.W.P. 1996b. The effect of water supply on the response of onions and cala- brese to starter solutions. Acta Horticulturae 428: 141-150.

-, Vaidyanathan, L.V. \& Paterson, C.D. 1992. Nitrogen residues from Brassica crops. Aspects of Applied Biology 30: 263-269.

Riley, H. \& Guttormsen, G. 1993a. N requirements of cabbage crops grown on contrasting soils. I: Field trials. Norwegian Journal of Agricultural Sciences 7: 275-291.

- \& Guttormsen, G. 1993b. N requirements of cabbage crops grown on contrasting soils. Il: Model verification and predictions. Norwegian Journal of Agricultural Sciences 8: 99-113.

Robson, A.D., Longnecker, N.E. \& Osborne, L.D. 1992. Effects of heterogeneous nutrient supply on root growth and nutrient uptake in relation to nutrient supply on duplex soils. Australian Journal of Experimental Agriculture 32: 879-886.

Roll-Hansen, J. 1974. Gulrot i gjødslingsforsøk på myrjord. (Abstract: Fertiliser experiments with carrots on peat soil. Forskning og Forsøk i Landbruket 25: 202218.

- 1976. Gulrot i gjødslingsforsøk på sandjord. (Abstract: Fertiliser experiments with carrots on sandy soil). Forskning og Forsøk i Landbruket 27: 55-71.

Rowse, H.R., Costigan, P.A. \& Thompson, A.R. 1988. Sub-seed injection of fertilizers and pesticides Equipment and preliminary results. Proceedings of the 11th International Conference of the International Soil Tillage Research, 11-15th July, Edinburgh, Scotland. p. 845-850.

Scaife, A. \& Turner, M. 1983. Diagnosis of Mineral Disorders in Plants. Volume 2. Vegetables. Ministry of Agriculture, Fisheries and Food/Agricultural Research Council. HMSO, London, England. 96 p.

Scharpf, H.-C. \& Weier, U. 1996. Investigations on the nitrogen dymanic as a basis for the $\mathrm{N}$ fertilizer recommendations in vegetable production. Acta Horticulturae 428: 73-83.

Schloemer, S. 1991. Denitrifikation eines gemüsebaulich genutzten Bodens in Abhängigkeit von der Einarbeitung frischer Erntereste. Zeitschrift für die Pflanzenernährung und die Bodenkunde 154: 265-269.

Sippola, J. 1982. A comparison between a dry combustion method and rapid wet combustion method for determining soil organic carbon. Annales Agriculturae Fenniae 21: 146-148.

Slangen, J.H.G., Titulaer, H.H.H., Schroën, G.J.M., Quik, P., Everaarts, A.P. \& de Moel, C.P. 1990. Stikstofbemesting van witte kool, veldproeven 1982-1987. Report 109. PAGV, Lelystad. 59 p. (In Dutch).

Smith, C.B., Demchak, K.T. \& Ferretti, P.A. 1990. Fertilizer placement effects on growth responses and nutrient uptake of sweet corn, snapbeans, tomatoes and cabbage. Communications in Soil Science and Plant Analysis 21: 107-123.

Smucker, A.J., McBurney, S.L. \& Srivaastava, A.K. 1982. Quantitative separation of roots from compacted soil profiles by the hydropneumatic elutriator system. Agronomy Journal 74: 500-503.

Soil Testing Laboratory of Finland 1992. Viljavuustutkimuksen tulkinta avomaan puutarhaviljelyssä. Hel- 


\section{AGRICULTURAL AND FOOD SCIENCE IN FINLAND}

Salo, T. Effects of nitrogen fertilizer on growth of cabbage, carrot and onion

sinki. 16 p. (in Finnish).

- 1997. Viljavuustutkimuksen tulkinta avomaan puutarhaviljelyssä. Mikkeli. 20 p. (in Finnish).

Sørensen, J.N. 1993. Use of the $\mathrm{N}_{\text {min }}$-method for optimization of vegetable nitrogen nutrition. Acta Horticulturae 339: 179-192.

- 1996. Improving $N$ efficiency in vegetable production by fertilizer placement and irrigation. Acta Horticulturae 428: 131-140.

Suojala, T., Salo, T. \& Pessala, R. 1998. Effects of fertilization and irrigation practices on yield, maturity and storability of onions. Agricultural and Food Science in Finland 7: 477-488.

Taivalmaa, S.-L. \& Talvitie, H. 1997. The effects of ridging, row-spacing and seeding rate on carrot yield. Agricultural and Food Science in Finland 6: 363-369.

Tecator 1981. Application note. AN 30/81. Determination of Kjeldahl Nitrogen content with Kjeltec auto systems I, II, III, and IV. In: Tecator Manual. Kjeltec Auto 1030 Analyzer. Sweden. 43 p.

Tei, F., Scaife, A. \& Aikman, D.P. 1996. Growth of let- tuce, onion and red beet. 1. Growth analysis, light interception and radiation use efficiency. Annals of Botany 78: 633-643.

Thorup-Kristensen, K. 1994. The effect of nitrogen catch crop species on the nitrogen nutrition of succeeding crops. Fertilizer Research 37: 227-234.

Vuorinen, J. \& Mäkitie, O. 1955. The method of soil testing in use in Finland. Agrogeological Publication 63 : $1-44$.

Welch, N.C., Tyler, K.B. \& Ririe, D. 1985a. Cabbage yield and nutrient uptake. California Agriculture 39, 7-8: 30-31.

-, Tyler, K.B., Ririe, D. \& Broadbent, F.E. 1985b. Nitrogen uptake by cauliflower. California Agriculture 39, 5-6: 12-13.

Wiedenfeld, R.P. 1986. Rate, timing and slow-release nitrogen fertilizers on cabbage and onions. HortScience 21: 236-238.

Youngs, E.G. 1991. Hydraulic conductivity of saturated soils. In: Smith, K.A. \& Mullins, C.E. (eds.). Soil Analysis. Physical Methods. New York. USA. p. 161-208. 


\title{
AGRICULTURAL AND FOOD SCIENCE IN FINLAND
}

Vol. 2 (1999): 157-232.

\section{SELOSTUS}

\author{
Typen sijoittamisen ja typpilannoitustason vaikutus keräkaalin, porkkanan ja sipulin \\ kuiva-ainetuotantoon, satoon ja typenottoon \\ Tapio Salo \\ Maatalouden tutkimuskeskus
}

Typpilannoituksen optimoimiseksi tarvitaan tietoa eri satotasojen vaatimista typpimääristä ja typenoton rytmistä kasvukauden aikana. Viljoilla typen sijoittaminen on lähes ainoa levitystapa Suomessa, mutta typen sijoittamisen vaikutusta vihannesten kasvuun ei ole juurikaan tutkittu. Tutkimuksessa verrattiin vuosina 1993-1994 typpilannoitustason ja typen hajalevityksen sekä sijoittamisen vaikutusta maan mineraalityppipitoisuuksiin, kaalin (Castello), porkkanan (Narbonne) ja sipulin (Sturon) kuiva-ainetuotantoon, satoon ja typenottoon. Vuonna 1995 koekasvien kasvua ja typenottoa mitattiin vain lannoittamattomasta ja optimiksi arvioidusta typpilannoitustasosta.

Kaali tarvitsi runsaasti typpeä hyvän satotason saavuttamiseksi. Sekä kerät että ulkolehdet sisälsivät typpeä $150 \mathrm{~kg} \mathrm{ha}^{-1} 60 \mathrm{t} \mathrm{ha}^{-1}$ satotasolla, eli kaalikasvusto otti tällä satotasolla yhteensä $300 \mathrm{~kg} \mathrm{ha}^{-1}$ typpeä. Kaali oli kuitenkin tehokas maasta vapautuvan typen hyödyntäjä, minkä osoittivat typenotot lannoittamattomista käsittelyistä, $90 \mathrm{~kg} \mathrm{ha}^{-1}$ vuonna 1993 ja peräti $159 \mathrm{~kg} \mathrm{ha}^{-1}$ vuonna 1994. Porkkanan satotaso vaihteli 75-100 t ha-1 ${ }^{-1}$ ja maanpäällisen kasvuston typenotto oli $135-178 \mathrm{~kg} \mathrm{ha}^{-1}$. Porkkanan naateissa oli noin kolmannes koko maanpäällisen kasvuston sisältämästä typestä. Sipulin typentarve oli suurimmillaan $120 \mathrm{~kg} \mathrm{ha}^{-1}$, joka saavutetaan nykyisillä 80-100 kg ha${ }^{1}$ typpilannoitussuosituksilla. Sipulin ottamasta typestä neljännes oli naateissa. Sipuli pystyi hyödyntämään maasta vapautuvaa typpeä heikosti, lukuunottamatta vuotta 1994, jolloin lannoittamattoman sipulikasvuston typenotto oli $81 \mathrm{~kg} \mathrm{ha}^{-1}$.

Kasvien typpipitoisuudet pienenivät kuiva-ainesadon lisääntyessä. Kaalin ja sipulin typpipitoisuudet olivat lannoittamattomissa kasveissa pienemmät kuin lannoitetuissa, ja aineiston perusteella voidaan arvioida kasvulle kriittistä typpipitoisuutta. Kaalin ja sipulin typenotto oli ensimmäisen kuukauden aikana vähäistä, mutta jatkui tämän jälkeen sadonkorjuuseen asti nopeana. Porkkanan nopea typenoton vaihe alkoi sitä vastoin vasta kahden kuukauden kuluttua kylvöstä ja jatkui sadonkorjuuseen asti. Kokeen tulosten pe- rusteella porkkana hyödyntää hyvin maasta vapautuvaa typpeä, ja lannoitetypen tarve on vähäinen verrattuna muihin vastaavia typpimääriä tarvitseviin kasveihin kuten esimerkiksi sipuliin. Porkkanan typpilannoitusta voitaisiinkin todennäköisesti vähentää multavilla hieta- ja turvemailla.

Kaalikasvustossa typen sijoittaminen aiheutti kasvukauden alussa typen puutetta ja heikentynyttä kasvua. Kasvukauden kuluessa erot vähenivät, mutta ensimmäisenä koevuonna tuoresato jäi sijoitetuissa käsittelyissä $6 \%$ pienemmäksi kuin hajalevitetyissä. Typpi sijoitettiin $7,5 \mathrm{~cm}$ taimen sivuun ja $7 \mathrm{~cm}$ syvyyteen alapuolelle. Tämä oli ilmeisesti liian kaukana taimista, sillä taimien alkukehitys hidastui. Kuukauden kuluttua istutuksesta suurin osa $8 \mathrm{~cm}$ syvään pintakerrokseen hajalevitetystä typestä oli $0-5 \mathrm{~cm}: n$ syvyydessä, kun taas sijoitettu typpi oli lähinnä 5-10 cm:n syvyydessä. Typpilannoitus lisäsi kaalien typpipitoisuuksia, kuiva-ainetuotantoa ja typen ottoa. Vuonna 1993 kaalin sato ja kuiva-ainetuotanto lisääntyivät aina suurimpaan $250 \mathrm{~kg} \mathrm{ha}^{-1}$ typpilannoitustasoon asti. Vuonna 1994 maan typen mineralisaatio oli niin voimakasta, että vain lannoittamattomien kasvustojen kuiva-ainetuotanto ja typenotto olivat vähäisempiä kuin muiden käsittelyjen. Kaalin sadonkorjuun jälkeen maan mineraalitypen määrä oli alle $25 \mathrm{~kg} \mathrm{ha}^{-1}$.

Typpilannoitus ei vaikuttanut porkkanan kuivaainetuotantoon ja sadonmuodostukseen. Porkkanan typpipitoisuus sen sijaan lisääntyi typpilannoituksen seurauksena. Suurin typpilannoitustaso lisäsi maan liukoisen typen määrää noin $20 \mathrm{~kg} \mathrm{ha}^{-1}$ verrattuna lannoittamattomaan käsittelyyn. Typen sijoittaminen harjun sisään ei vaikuttanut porkkanan kasvuun tai typenottoon. Ilmeisesti kasvualustan typpipitoisuudet ovat tasaantuneet, kun porkkanan voimakas kasvu alkaa noin kahden kuukauden kuluttua kylvöstä. Koska lannoitusmenetelmien ja -tasojen välillä ei havaittu eroja, koetta jatkettiin vuonna 1994 vain eri lannoitustasoilla.

Ensimmäisenä koevuonna sipuli kasvoi hyvin. Sekä typen sijoittaminen $5 \mathrm{~cm}$ istukkaiden sivulle ja 


\section{AGRICULTURAL AND FOOD SCIENCE IN FINLAND}

Salo, T. Effects of nitrogen fertilizer on growth of cabbage, carrot and onion

$7 \mathrm{~cm}$ alapuolelle että runsas typpilannoitus nostivat sadon $45 \mathrm{t} \mathrm{ha}^{-1}$ tasolle. Toisena koevuonna sato jäi alle $35 \mathrm{t} \mathrm{ha}^{-1}$ tasolle, eivätkä käsittelyt vaikuttaneet kasvuun. Typen parempi saatavuus joko typen sijoittamisen tai runsaamman lannoituksen ansiosta lisäsi sen sijaan molempina vuosina sipulin typpipitoisuutta. Suurempi typpipitoisuus ei kuitenkaan välttämättä lisännyt kasvua. Kasvuston typenotto sen sijaan yleensä lisääntyi.

Lannoitetypen näennäinen hyväksikäyttö oli koevuosina tehokasta. Sipulin lannoitetypen näennäinen hyväksikäyttö parantui ensimmäisenä koevuonna sijoituslannoituksen avulla ja väheni typpilannoituksen lisääntyessä. Toisena koevuonna käsittelyt eivät vai- kuttaneet lannoitetypen hyväksikäyttöön. Hyväksikäyttö oli toisinaan yli $100 \%$, koska kohtuullinen lannoitus paransi maasta vapautuvan typen hyödyntämistä.

Typen sijoittaminen tai hajalevitys eivät kokeen tulosten perusteella vaikuta ratkaisevasti kaalin, porkkanan ja sipulin sadontuotantoon. Hajalevitys takasi kaalille riittävästi typpeä kasvun alkuvaiheessa. Sipuli sitä vastoin hyötyi sijoittamisesta, kun kasvuolosuhteet olivat hyvät ja maan ravinnetila huono. Kaikki koekasvit todennäköisesti hyötyisivät typen sijoituslannoituksesta kuivissa olosuhteissa, joissa kastelua ei ole mahdollista järjestää. 